\title{
FGF/ERK autocrine signaling is enhanced by NANOG in a subpopulation of pluripotent stem cells to execute autoregulation and induce heterogeneity
}

Hanuman T Kale, Rajendra Singh Rajpurohit, Debabrata Jana, Vishnu V Vijay, Mansi

Srivastava, Preeti R Mourya, Gunda Srinivas, P Chandra Shekar*

CSIR-Centre for Cellular and Molecular Biology, Uppal Road, Hyderabad, Telangana, India 500007.

*Correspondence: csp@ccmb.res.in

\section{SUMMARY:}

FGF/ERK autocrine signaling induces Nanog heterogeneity, allelic switching, and differentiation in pluripotent cells, which are abolished in the naive-state (2i) by inhibition of MEK1/2 and GSK3 $\beta$. Surprisingly Nanog autorepression is functional in $2 \mathrm{i}$. The mechanisms activating FGF signaling and its downstream effectors leading to heterogeneity and allelic switching are unknown. We utilized genome-edited fluorescent reporter cell lines of both Nanog promotor and protein to elucidate, a NANOG induced FGF autocrine signaling mediated autoregulatory mechanism. We show that Nanog autoregulation is a cell nonautonomous process initiated by NANOG, but executed by FGF/ERK. FGFR2 differentially activates autoregulation in Nanog-high cells by activating ERK1/2. pERK1/2 recruits NONO (P54nrb) to repress Nanog transcription. Collectively, we show that Nanog-induced FGF autocrine signaling mediated autoregulation is the basis of Nanog heterogeneity and allelic switching. Our data introduces an unexpected reciprocal regulatory mechanism between NANOG and FGF/ERK signaling feeding into each other's heterogeneity.

\section{INTRODUCTION}

Embryonic stem (ES) cells are characterized by long-term self-renewal and the potential to differentiate to all cell types of the germ layers. ES cells cultured in presence of serum and LIF (metastable state) manifest transcriptional and functional heterogeneity. The heterogeneous 
expression of transcription factors like Nanog, Rex1, Stella, Esrrb, Klf4, and Tbx3 determine differential fate choice (Chambers et al., 2007; Festuccia et al., 2012; Filipczyk et al., 2013; Hayashi et al., 2008; Kalmar et al., 2009; Niwa et al., 2009; Torres-Padilla and Chambers, 2014; Toyooka et al., 2008; van den Berg et al., 2008). The molecular heterogeneity arising from the modulation of transcription factors by non-genetic factors underpins the functional heterogeneity of the subpopulations of ES cells. The core pluripotency factor, Nanog was identified as a factor conferring LIF independent self-renewal to ES cells by inhibiting differentiation (Chambers et al., 2003; Mitsui et al., 2003). Nanog imparts functional heterogeneity to ES cells through its heterogeneous expression leading to differential cell fate choices (Chambers et al., 2007; Kalmar et al., 2009). Unlike other core pluripotency factors, Nanog switches between mono-allelic and bi-allelic expression during embryonic development and in alternate pluripotency states (Filipczyk et al., 2013; Miyanari and Torres-Padilla, 2012). The expression of Nanog is restricted in ES cells to ensure their potential to differentiate by negative feedback autorepression and other repressive mechanisms (Fidalgo et al., 2012; Fidalgo et al., 2011; Mora-Castilla et al., 2010; Navarro et al., 2012; Pereira et al., 2006).

FGF/ERK signaling represses Nanog to induce heterogeneity and monoallelic expression, which are abolished in ESCs cultured in 2i (Filipczyk et al., 2013; Miyanari and TorresPadilla, 2012). Intriguingly, Nanog autorepression is functional in 2i, suggesting MEK1/2 and GSK3 $\beta$ are dispensable for Nanog autoregulation (Navarro et al., 2012). Hence, the mechanisms regulating the three paradigms of Nanog regulation- heterogeneity, allelic expression, and autorepression are not entirely connected through FGF signaling. Although FGF/ERK represses Nanog expression (Hamazaki et al., 2006; Kim et al., 2014), the mechanistic delineation of this process is limited, and it is unclear how the NANOG protein levels are sensed by cells to trigger autorepression. Here, we utilized genetic approaches in Nanog fluorescent reporter cell lines and biochemical experiments to unravel a detailed mechanism of Nanog autoregulation. We show that MEK1/2 is essential for Nanog autoregulation. NANOG induces components of the FGF autocrine pathway in cells with higher Nanog expression, to trigger feedback repression by activation of ERK1/2. Fgfr2 gene acts as a sensor of the NANOG protein in Nanog high cells. Further, we show that pERK1/2 interacts and recruits NONO to repress Nanog transcription. Surprisingly Nanog is essential only for triggering the autoregulation process but dispensable for its execution. Our results establish that the different facets of Nanog expression- heterogeneity, allelic switching, and autoregulation are regulated and interlinked by FGF autocrine signaling. 


\section{RESULTS}

\section{Residual MEK1/2 activity in the ground state prevents complete derepression of Nanog.}

Nanog exhibits homogenous and biallelic expression in $2 \mathrm{i}$. To uncouple the influence of MEK1/2 and GSK3 $\beta$ on Nanog expression, we analyzed the activity of endogenous Nanog gene activity reported by GFP in TNGA and T $\beta$ C44Cre6 cell lines (Chambers et al., 2007) in different combinations of MEK1/2 and GSK3 $\beta$ inhibitors. Nanog promoter activity was derepressed in MEK1/2 inhibition (SLPD), GSK3 $\beta$ inhibition (SLCHIR), and 2i. Surprisingly Nanog promoter activity was higher in SLPD than in 2i (Figure1A, 1B). To analyze NANOG protein dynamics, we generated a NiRFP2A cell line with an iRFP670 coding sequence fused to the c-terminal of both alleles of Nanog (Figure S1A). Higher NANOGiRFP in SLPD (Figure1C, S1B), reaffirmed the highest induction of Nanog transcript and protein in SLPD. To dismiss the interference of any genetic modifications in the Nanog locus on its expression (Faddah et al., 2013); Nanog expression was analyzed in E14Tg2a cells. The Nanog transcript (Figure1D), transcriptional activity (Figure1E), and protein (Figure1F) were highest in SLPD. On the contrary, Oct4 transcript and transcription activity were enhanced but protein changed very little in SLPD (Figure1D-F, S1C). NANOG was nearly 7-fold more in PD, which is twice that of $2 \mathrm{i} / \mathrm{SL} 2 \mathrm{i}$ (Figure1F). Although SLPD and $2 \mathrm{i}$ contain $1 \mu \mathrm{M}$ PD, higher Nanog expression in SLPD indicates inefficient repression of Nanog in 2i/SL2i. We analyzed MEK1/2 substrate -pERK1/2 to investigate possible modulation of MEK1/2 activity by GSK3 $\beta$ (Yun et al., 2005). The pERK1/2 levels in ESCs changed dynamically throughout $24 \mathrm{hrs}$ after the SL media was changed. The pERK1/2 remained undetectable up to $4 \mathrm{hrs}$ in SLPD and 2i/SL2i. It gradually increased in $2 \mathrm{i}$ after $8 \mathrm{hrs}$ but remained undetectable in SLPD (Figure 1G, S1D). We further analyzed pERK1/2 at different time points of treatment in PD, CHIR, and 2i/SL2i relative to SL after $24 \mathrm{hrs}$ of media change (SL-24h). The pERK1/2 in SLCHIR and 2i significantly exceeded SL and SLPD respectively by 24 hrs (Figure 1H, S1E), suggesting a long-term CHIR treatment enhanced MEK1/2 activity in ESCs. Further, the PD and CHIR dose-responsive experiments confirmed that the pERK1/2 positively correlated with the CHIR concentrations (Figure 1I-J, S1F-I). Collectively, our data demonstrate that Nanog attains higher expression in MEK1/2 inhibition than in $2 \mathrm{i}$. GSK3 $\beta$ activity negatively modulates MEK1/2 activity and its inhibition by CHIR increases pERK1/2 
in $2 \mathrm{i}$ over time.

\section{FGF autocrine signaling pathway components are essential for Nanog autoregulation.}

The Nanog expression is higher in SLPD than $2 \mathrm{i}$ and Nanog autorepression is functional in $2 \mathrm{i}$ (Navarro et al., 2012). We asked if all repressive mechanisms including the Nanog autorepression are abolished in SLPD. To address this, we generated two independent NANOG restoration systems by integrating Flag-Avi-NANOG-ER ${ }^{\mathrm{T} 2}\left(\mathrm{NANOGER}^{\mathrm{T} 2}\right)$ and a Doxycycline-inducible Flag-Avi-NANOG (FaNANOG) transgene in T $\beta$ c44Cre6 (Chambers et al., 2007) to derive the TNERT and TDiN cell lines respectively. TNERT and TDiN are similar to NERTc3 and 44iN (Festuccia et al., 2012; Navarro et al., 2012) where the NANOG function is reinstated by 4-Hydroxytamoxifen (OHT) or Doxycycline respectively, and endogenous Nanog gene activity is reported by GFP (Figure 2A, S2A-B). The repression of Nanog:GFP upon induction of transgenic NANOG by OHT/Dox is a functional readout of Nanog autoregulation. Nanog:GFP was repressed in OHT/Dox treated TNERT/TDiN in SL, SLCHIR, 2i, and SL2i, but not in SLPD (Figure 2A, S2C-D). To analyze the dynamics of endogenous NANOG in Nanog autoregulation, we generated NsGFPDiN cell line. The NANOG-GFP fusion protein is produced from one of the alleles of Nanog and a Doxycycline-inducible FaNANOG transgene is randomly inserted (Figure 2B). The NANOG-GFP was repressed in all treatments except in SLPD in Doxycycline treatment (Figure 2B, S2E). The data from distinct cell lines conclusively establish an essential role of MEK1/2 in Nanog autoregulation. We propose that the residual pERK1/2 resulting from residual MEK1/2 activity in $2 \mathrm{i}$ is sufficient for the functioning of Nanog autoregulation.

FGF autocrine signaling is the predominant inducer of MEK/ERK in pluripotent cells (Kunath et al., 2007; Lanner and Rossant, 2010), we investigated the role of FGF signaling components in autoregulation. NANOGER ${ }^{\mathrm{T} 2} / \mathrm{FaNANOG}$ failed to repress Nanog:GFP in presence of FGFR inhibitor- SU5402, suggesting an essential role of FGFRs in Nanog autoregulation (Figure 2C, S2F). FGFR1, FGFR2, and FGF4 are major receptors and ligands of FGF signaling in early embryos respectively (Kang et al., 2017; Molotkov et al., 2017). FGFBP1 is a carrier protein expressed from early to late blastocyst (Figure 2D) (Park et al., 2015) that enhances FGF signaling (Tassi et al., 2001). We deleted Fgfrl, Fgfr2, Fgf4, and Fgfbpl in TNERT cells to analyze their role in autoregulation (Figure 2E, S2G-J). Except in 
TNERTFgfr1-/-, Nanog:GFP was not repressed in TNERTFgfr2-/-, TNERTFgf4-/- and TNERTFgfbp1-/- cells upon OHT induction (Figure 2F). Our data suggest that FGF autocrine signaling and its components FGFR2, FGF4, and FGFBP1 are essential for Nanog autoregulation.

\section{Nanog enhances the expression of FGF autocrine signaling pathway components.}

We analyzed the expression of FGF autocrine signaling components during the time course of OHT induction. Fgf4, Fgfr2, Fgfrl, and Fgfgbpl transcripts were induced within 1-2 hrs (Figure 3A), Esrrb a direct target of NANOG was induced within 0.5 hrs. Increased premRNA of $F g f 4, F g f r 2, F g f b p l$, and Fgfrl indicated transcriptional activation of FGF signaling pathway components after OHT induction (Figure 3B). ChIP-seq data analysis identified NANOG occupancy on Fgf4, Fgfbpl, Fgfrl, and Fgfr2, which was further enhanced in Oct4+/- cells that have higher NANOG (Figure S3A) (Karwacki-Neisius et al., 2013). To analyze dosage-dependent occupancy of NANOG on these genes, we generated EDiN cell line by introducing a Doxycycline- inducible FaNANOG transgene in E14Tg2a. ChIP-PCR confirmed NANOG occupancy on Fgf4, Fgfbpl, Fgfrl, and Fgfr2, which was further enhanced in PD (Figure 3C) and EDiN+Dox (Figure 3D) which express higher NANOG. The data suggest a dose-dependent occupancy of NANOG on the FGF signaling component genes. FGFR1, FGFR2, and pERK1/2 were significantly increased upon OHT induction in TNERT (Figure 3E). The strength of FGF signaling depends on facilitation by carrier proteins (Tassi et al., 2001), the affinity of ligands (Ornitz et al., 1996; Zhang et al., 2006), and subsequent subcellular trafficking of the FGFRs after ligand-mediated activation (Auciello et al., 2013; Francavilla et al., 2013). The induction of NANOGER ${ }^{\mathrm{T} 2}$ enhanced FGFR2 on the cell surface (Figure 3F), unlike the FGFR1 (Figure S3B). The NANOGER ${ }^{\mathrm{T} 2}$ induction increased FGF4 and FGFBP1 secretion by TNERT (Figure 3G- H, S3C-D). Collectively the data shows that increased NANOG enhances FGFR2 on the cell surface, and secretion of FGF4 and FGFBP1 to intensify the FGF autocrine signaling. NANOG induces and enhances FGF autocrine signaling to execute Nanog autoregulation.

\section{Nanog autoregulation is a cell non-autonomous process mediated by FGF autocrine/paracrine signaling.}


Nanog autorepression is suggested to operate by a cell-autonomous process through intracellular proteins NANOG, ZFP281, and NURD complex (Fidalgo et al., 2012). However, Cell non-autonomous function of Nanog in the induction of primitive endoderm (Frankenberg et al., 2011; Messerschmidt and Kemler, 2010) and the essential role of secreted proteins FGF4 \& FGFBP1 in autoregulation from our experiments prompted us to investigate cell non-autonomous mechanisms. We assessed the ability of conditioned media from OHT induced TNERT cells, to repress Nanog:GFP in T $\beta$ c44Cre6 lacking Nanog (Figure 3I). The conditioned media was sufficient to repress the Nanog:GFP (Figure 3J, S3E), suggesting that autoregulation operates via cell non-autonomous mechanisms and discounts the direct role of NANOG in autorepression as proposed earlier (Fidalgo et al., 2012). NANOG seems to be essential for triggering autoregulation through FGF signaling components but does not participate in repression. This led us to investigate the role of ZFP281 in Nanog autoregulation. The repression of Nanog:GFP upon OHT treatment, in TNERTZfp281-/- cell line lacking Zfp281 (S3F) suggests that ZFP281 is dispensable for Nanog autoregulation (Figure 3K).

To evaluate if FGF4 secretion was the causative factor of Nanog autoregulation in the conditioned media, we treated $\mathrm{T} \beta \mathrm{c} 44 \mathrm{Cre} 6$ with conditioned media from cells with loss or gain of FGF4. The conditioned media from an E14Tg2a cell line overexpressing FGF4 or supplementation of FGF4 (50ng/ml) could repress Nanog:GFP. Conversely, the conditioned media from OHT induced TNERTFgf4-/- or from TNERT+OHT-0 hr cells failed to repress Nanog:GFP, suggesting FGF4 is the key secreted factor essential for Nanog autoregulation (Figure 3L, S3G). The ELISA analysis confirmed the secretion and accumulation of FGF4 and FGFBP1 in the conditioned media (S3H-K). Collectively, our data establish that Nanog autoregulation is a cell non-autonomous process triggered by NANOG by augmenting FGF autocrine/paracrine signaling.

\section{NANOG-induced FGFR2 triggers autoregulation predominately in the ES cell population with higher Nanog expression.}

Nanog autoregulation was proposed to restrict NANOG levels within limits to retain the differentiation potential (Fidalgo et al., 2012; Navarro et al., 2012). Nanog autoregulation is expected to operate only in Nanog-high cells and not in Nanog-low cells. To evaluate this logic, we used TDiN cell lines with different induction levels of FaNANOG (Figure S4A). 
The strength of Nanog autoregulation was found to be dependent on the FaNANOG levels and was completely abolished in TDiN clone with low FaNANOG (Figure S4B, 4C). To analyze autoregulation in Nanog-high and Nanog- low cells, we sorted the lowest and the highest $10 \%$ population of the TNERT expressing GFP and treated with OHT. The Nanog:GFP was repressed in Nanog-high cells but not in Nanog-low cells (Figure 4A). Our experiments demonstrate the logic of Nanog autoregulation and conclude that Nanog autoregulation predominately operates in Nanog-high and not in Nanog-low cell population. FGF4 and FGFBP1 are secretory proteins, hence cannot distinguish between the Nanog- high and low cells in culture. Whereas FGFRs are essential for autoregulation and are retained on the cells, we asked if FGFRs functioned as a sensor for the NANOG levels to distinguish Nanog-high cells from low cells. We analyzed the correlation between the expression of FGFR1 and FGFR2 vis-à-vis NANOG in E14Tg2a by FACS. FGFR2 and FGFR1 showed a strong correlation with NANOG, which was further enhanced for FGR2-NANOG in SLPD $(\mathrm{r}=0.80)$ whereas decreased for FGFR1-NANOG ( $\mathrm{r}=0.59)$ in SLPD (Figure 4B,) where NANOG levels are higher. These data suggested FGFR2 but not FGFR1 expression levels correlate and respond to NANOG concentration in the cells. FACS analysis showed high FGFR2 in the 10\% NANOG high population and lower FGFR2 in the 10\% NANOG low population (Figure 4C). The dose-dependent binding of NANOG to $F g f r 2$ and a strong FGFR2-NANOG correlation suggest that the Fgfr2 gene may function as a sensor for NANOG concentration in the cells. To test this possibility, we analyzed the NANOG binding sequences in the Fgfr2 locus. Two NANOG binding regions (NBR) with multiple NANOG binding sequences were identified in the Fgfr2 locus from the ChIP-seq (Karwacki-Neisius et al., 2013), NBR1 at $1.4 \mathrm{~kb}$, and NBR2 at $-0.2 \mathrm{~kb}$ relative to TSS of Fgfr2. NBR1 and NBR2 were deleted in TNERT (Figure 4D-E, S4D-E). Autoregulation was operational in TNERTNBR1-/- albeit at reduced strength, whereas it was abolished in TNERTNBR2-/(Figure 4F), suggesting that NBR2 is essential for the binding of NANOG and activation of Fgfr2 to trigger autoregulation. Together, our data suggest dose-responsive induction of $F g f 4$, Fgfbpl, and Fgfr2 by NANOG. The Nanog-high cells secrete more FGF4 and FGFBP1, also express higher FGFR2 receptors. The FGF4 in presence of FGFBP1 binds to FGFR2 to enhance FGF signaling in Nanog-high cells to activate pERK1/2 and repress Nanog. The Nanog-low cells express relatively low FGFR2, resulting in weak FGF signaling and the absence of autoregulation (Figure 4G). We propose that FGFR2 distinguish the Nanog-high cells from the low cells to activate autoregulation predominately in Nanog- high cells. 


\section{ERK1/2 interacts and recruits NONO to repress Nanog transcription.}

The FGF signaling cascade leads to phosphorylation of ERK1/2. pERK could activate downstream targets like Tcf15 to repress Nanog (Davies et al., 2013) or ERK can recruit chromatin regulators like NONO to induce poised pol2 state in developmental bivalent genes (Ma et al., 2016). To examine these possibilities in autoregulation, we deleted Tcf15 and Nono in TNERT (Figure 5A, S5A, B). Unlike in TNERTTcf15-/- cells, OHT treatment failed to repress Nanog:GFP in TNERTNono-/- cell indicating essential role of NONO in autoregulation (Figure 5B, S5C). pERK1/2 was substantially reduced in TNERTNono-/despite OHT induction, unlike in TNERT (Figure 5C, S5D). Endogenous immunoprecipitation showed an interaction between NONO and ERK1/2 in the presence or absence of NANOG (Figure 5D). NONO colocalizes with ERK1/2 to bivalent developmental genes to maintain poised POL2 (Ma et al., 2016). Although Nanog is an actively transcribed gene lacking bivalent marks, the indispensability of NONO and pERK1/2 for autoregulation prompted us to investigate if they bind to Nanog and repress its transcription. The ChIP-seq data analysis (Ma et al., 2016; Tee et al., 2014) indicated NONO and ERK1/2 binding on the Nanog (S5E). We induced or repressed the pERK1/2 by treatment of E14Tg2a cells with FGF4 or PD respectively (Figure 5E) and analyzed the occupancy of NONO, pERK1/2, POL2, H3K4me3, and H3K27me3. The Transcription Start Site (TSS) and $5 \mathrm{~kb}$ upstream region $(-5 \mathrm{~kb})$ are the two hubs of transcription factor binding and control of Nanog transcription (Chen et al., 2008; Loh et al., 2006). We performed ChiP-qPCR analysis with multiple primer sets spanning the $-5.8 \mathrm{~kb}$ to $+1.5 \mathrm{~kb}$ region relative to TSS (Figure 5F). pERK1/2 binding was detected in immediate downstream regions of the $-5 \mathrm{~kb}$, and TSS. pERK1/2 binding was reduced significantly in PD and enhanced in FGF4 suggesting pERK1/2 binding to Nanog is dependent on FGF activity (Figure 5G). NONO binds to Nanog at the TSS and its downstream, which is enhanced in FGF4 and abolished in PD treatment suggesting pERK1/2 recruits NONO to Nanog (Figure 5H). POL2 occupancy seen in TSS and downstream region was reduced in FGF4 and enhanced in PD treatment. This suggested active transcription of Nanog in PD and repression in FGF4 (Figure 5I). This was further corroborated with enhanced enrichment of the transcription activating histone mark $\mathrm{H} 3 \mathrm{~K} 4 \mathrm{me} 3$ in PD (Figure 5J) and enrichment of transcription repressive mark H3K27me3 at the $-5 \mathrm{~kb}$ region of the Nanog in FGF4 treatment (Figure 5K). pERK1/2 phosphorylates 
NANOG, USP21 and affects NANOG stability and transactivation capability (Brumbaugh et al., 2014; Jin et al., 2016; Kim et al., 2014). In agreement with NANOG destabilization by pERK1/2 (Brumbaugh et al., 2014; Kim et al., 2014; Pokrass et al., 2020), The half-life of NANOG was significantly compromised in FGF4 treated cells but enhanced in PD (Figure 5L, S5F), suggesting that the FGF/ERK represses Nanog transcription and also affects NANOG stability. Collectively, these data suggest that FGF signaling activates pERK1/2 and its binding onto Nanog in a concentration-dependent manner. The recruitment of NONO to Nanog is dependent on the pERK1/2, NONO recruitment to Nanog is negligible in absence of pERK1/2. In the presence of pERK1/2-NONO, the POL2 loading on Nanog and its transcription activity is reduced resulting in repression of Nanog transcription. In the absence of active FGF signaling, pERK1/2-NONO occupancy on the Nanog is decreased permitting increased POL2 loading and transcription activation of the Nanog. The destabilization of NANOG by pERK1/2 further diminishes its ability to activate its promoter (Figure 5M).

\section{FGF autocrine signaling regulates heterogeneity and monoallelic expression of Nanog.}

The ESCs cultured in Serum+LIF on gelatin exhibit Nanog heterogeneity (Chambers et al., 2007; Filipczyk et al., 2013) which is lost when cultured on feeders or 2i (Faddah et al., 2013; Marks et al., 2012; Miyanari and Torres-Padilla, 2012). FGF signaling is substantially but discontinuously inhibited in $2 \mathrm{i}$, leading to near homogeneity of Nanog. The loss of heterogeneity on feeders could be due to the induction of Nanog expression by the extracellular matrix (ECM)-integrin signaling (Lee et al., 2010). Alternately FGF4 might be titrated out by the FGFRs on the feeders or by ECM secreted by the feeders rendering it unavailable for inducing autoregulation resulting in loss of heterogeneity. To evaluate these possibilities, we cultured TNGA in presence of FGF4 and PD on gelatin or feeders. The Nanog:GFP was heterogeneous in SL on gelatin and nearly homogenous on feeders; it was homogenous in SLPD and $2 \mathrm{i}$ on gelatin and feeders. it was repressed further in presence of FGF4 vis-à-vis SL on gelatin. The Nanog:GFP was heterogeneous even in cells cultured on feeders in presence of FGF4, suggesting that heterogeneity could be induced even on feeders in presence of an excess of FGF4 (Figure 6A). This discounts any major role for ECM-integrin mediated activation of Nanog expression contributing to the loss of heterogeneity on feeders. To negate possibilities of variations due to targeting strategies in the reporter cell lines (Faddah et al., 2013), we analyzed Nanog heterogeneity in E14Tg2a cells. Consistent with 
the observations in TNGA, the NANOG expression was homogenous in cells cultured in SLPD, 2i, and SLSU5402 on gelatin or feeders, and in SL on feeders (Figure S6A). The NANOG expression was heterogeneous in SL on gelatin and FGF4 was sufficient to induce heterogeneous NANOG expression in cells cultured on feeders (Figure 6B). Other growth factors like Insulin, EGF, and bFGF which can activate MEK1/2 also induced varying degrees of Nanog heterogeneity on feeders (S6A). Nanog expression was homogeneous in cells lacking FGF4 and FGFR2. Recombinant FGF4 substitution in media was sufficient to repress the Nanog and induce heterogeneity in FGF4-/- cells (Figure 6C). To quantify these observations, we generated OGNM cell line, where a randomly integrated Oct4-GFP transgene expression marks undifferentiated ES cells. The Nanog expression is reported by a T2AmCherry integrated in-frame with the last amino acid coding sequence of a Nanog allele (Figure 6D, S6B). The OGNM was cultured on gelatin or feeder or Feeder Secreted Matrix (FSM) and analyzed by FACS, to study the role of these substrates in Nanog heterogeneity. GFP expressing ES cells were gated and analyzed to avoid the feeders. Around 50\% of cells cultured on gelatin expressed T2AmCherry, which increased to $64 \%$ on feeders and $55 \%$ on FSM. Since the feeder contains feeder cells and FSM, T2AmCherry expression was increased by $9 \%$ over the FSM (Figure 6E, S6D), suggesting that the diminished heterogeneity observed on the feeder is an additive impact of the FSM and feeder cells. FGF4 repressed Nanog and enhanced heterogeneity on feeders and FSM. The Nanog expression was homogenous in $2 \mathrm{i}$ and PD on all substrates. Repression of Nanog in FGFR inhibitor SU5402 was significantly lower than PD (Figure 6E, S6D). EGF, bFGF, and Insulin repressed Nanog expression (S6C-D) suggesting MEK1/2 may be predominately activated by FGF signaling, but other growth factors can also contribute to the MEK1/2 activity in ESCs. We propose that the feeder cells and the matrix secreted by the feeders titrate out the FGF4 secreted by the ES cells and interrupt autoregulation of Nanog resulting in loss of heterogeneity of Nanog.

Monoallelic expression of Nanog is suggested to be underlying mechanisms for Nanog heterogeneity in ES cells and the embryos (Filipczyk et al., 2013; Marks et al., 2012). To analyze the expression of both the alleles of Nanog, we integrated an iRFP coding sequence in one allele and a GFP coding sequence in another allele in-frame with the last coding sequence of the Nanog to generate NANOGiRFP and NANOGsfGFP fusion protein from the two alleles (NsGiR) (Figure 6F, S6E). Around 32\% of the cells exhibited biallelic expression or no expression (32\%) and the rest showed monoallelic expression (36\%) in SL. CHIR reduced the monoallelic population (25\%) and enhanced both the biallelic and non-expressing populations. The reduced MEK1/2 activity in $2 \mathrm{i}$ and PD leads to biallelic expression in $90 \%$ 
of the cells. Around 75\% of the cells show biallelic expression in SU5402 treatment, with a significant population either showing monoallelic or no expression of Nanog. This further strengthens the suggestion that other growth factor signaling pathways may be feeding to MEK1/2 activity in ESCs. FGF4 significantly repressed both biallelic as well as monoallelic expression of Nanog leading to loss of Nanog expression in 50\% of the cells (Figure 6G). Together our data suggest that the FGF autocrine-driven Nanog autoregulation is interrupted by the FSM on feeders or by MEK1/2 inhibitor in 2i leading to loss of Nanog heterogeneity and monoallelic expression. This also establishes the primary role of feeder cells and FSM in the regulation of Nanog expression.

\section{DISCUSSION}

The inhibition of MEK1/2 and GSK3 $\beta$ in the ground state (2i) attenuates Nanog heterogeneity and monoallelic expression (Filipczyk et al., 2013; Nichols et al., 2009; Wray et al., 2010). Surprisingly, autorepression remains functional in $2 \mathrm{i}$, discounting the role of MEK1/2 and GSK3 $\beta$ in Nanog autorepression (Navarro et al., 2012). We attribute the highest possible de-repression of Nanog locus to a consistent low MEK1/2 activity in SLPD, unlike in 2i. Wnt signaling can activate MEK1/2 at multiple levels (Yun et al., 2005), hence activation of MEK1/2 in presence of CHIR may be mediated by downstream components of Wnt signaling. We suggest that the inhibition of MEK1/2 prevents differentiation in $2 \mathrm{i}$, but a time-dependent increase in MEK1/2 activity is significant and sufficient to facilitate Nanog autoregulation. Our findings open up the plausibility of other molecular processes regulated by MEK1/2 activity to be functional in $2 \mathrm{i}$.

In this study, we show that FGF autocrine signaling and its components are essential for Nanog autoregulation. Nanog is vital for the secretion of FGF4 and endoderm differentiation by cell-autonomous mechanisms (Frankenberg et al., 2011; Messerschmidt and Kemler, 2010). We show, NANOG binds to the promotors of Fgf4, Fgfrl, Fgfr2, and Fgfbpl; and induce their expression. As speculated earlier, NANOG targets-ESRRB and KLF4 may also induce some of the FGF signaling components, contributing to FGF signaling (Lakatos et al., 2014). Our data suggest that Nanog autoregulation is triggered above a threshold of NANOG, thereafter the intensity of repression is dependent on the levels of NANOG in the cells.

In a subpopulation of ES cells expressing high NANOG; NANOG activates the expression of $F g f 4, F g f r 2$, and $F g f b p 1$, leading to a state of high NANOG-high FGFR. The higher ERK1/2 
activity induced by high FGFR in these cells leads to the destabilization of NANOG. The Nanog transcription is also decreased by transcriptional repression by pERK1/2-NONO, leading to a state of low/medium NANOG-high FGFR/ERK. In embryos, such cells may exit pluripotency to form primitive endoderm. In cell culture, such cells might continue to selfrenew in presence of LIF. The reduced NANOG in these cells cannot anymore activate FGF signaling components leading to a low NANOG-low FGF/ERK state. The loss of FGF/ERK in such cells releases repression of Nanog and permits activation of Nanog by other transcription factors leading to cells with a high NANOG-low FGF/ERK state. This cycle of activation of FGF signaling by NANOG and repression of Nanog by FGF signaling might lead to heterogeneity of Nanog and heterogeneity of FGF/ERK (Figure 7A). ERK signaling heterogeneity is suggested to be a vital determinant of fate choice in ICM and ES cells (Bessonnard et al., 2014; Kang et al., 2017; Molotkov et al., 2017; Pokrass et al., 2020; Simon et al., 2020). The ERK heterogeneity has been suggested to originate due to differential local concentrations of FGF4 or heterogeneous expression of receptors FGFRs (FGFR1, FGFR2) or by negative feedback regulators (ETV5, DUSP1/6). Since FGFR1 is relatively uniformly expressed in the epiblast (Kang et al., 2017; Molotkov et al., 2017) and ESCs. Our findings may provide the basis of heterogeneous expression of FGFR2 and FGF4 in ESCs, which is dependent on NANOG concentration. The carrier protein FGFBP1 may locally enhance FGF signaling to induce ERK heterogeneity similar to heparan sulfate proteoglycans (Galanternik et al., 2015). We propose that reciprocal regulation of Nanog by FGF signaling and FGF signaling by NANOG as the basis for both NANOG and ERK heterogeneity.

Contradicting reports on Nanog heterogeneity (Chambers et al., 2007; Faddah et al., 2013; Filipczyk et al., 2013; Smith, 2013) attribute it to genetic manipulation strategies or culture on feeders or gelatin. Our study demonstrates that Nanog heterogeneity is induced by Nanog autoregulation triggered FGF autocrine signaling. The feeder cells and feeder secreted matrix interrupt this autoregulation to abolish heterogeneity (Figure 7B). Nanog autoregulation was speculated to regulate allelic switching and FGF4 signaling was considered dispensable for autorepression (Fidalgo et al., 2012; Navarro et al., 2012). Our study suggests that FGF autocrine signaling is essential for Nanog autoregulation and allelic switching (Figure 7C). We suggest that Nanog autoregulation is the molecular basis for Nanog heterogeneity.

Taken together, we demonstrate an essential role for FGF autocrine signaling in Nanog autoregulation, and different facets of Nanog regulation are intertwined and governed by FGF autocrine signaling. 


\section{Acknowledgments}

HTK was supported by a fellowship from ICMR (India), DJ, VVV, MS was supported by a fellowship from UGC (India). RSR was supported by DBT grant No: BT/PR14064/GET/119/16/2015. PCS was supported by WT/DBT IA grant No: 500053/Z/09/Z. We thank the Microscopy, and FACS core facilities of CCMB for the support extended to carry out this work. We thank Ian chambers, D P Kasbekar, and V R Chalamcharla for constructive comments on the manuscript.

\section{Author contributions}

Conceptualization, H.T.K, and P.C.S Methodology, H.T.K and P.C.S; Investigation, H.T.K, R.S.R., V.V.V., and G.S.; Writing - Original Draft, H.T.K. and P.C.S.; Writing - Review \& Editing, H.T.K., and P.C.S.; Funding Acquisition, P.C.S.; Resources, H.T.K, R.S.R., M.S., and D.J.; Visualization, H.T.K, and D.J.; Supervision, P.C.S.

\section{Declaration of interest:}

The authors declare no competing interests.

\section{Figure titles and legends:}

Figure 1: Residual MEK1/2 activity in ground state prevents complete derepression of Nanog. (A) (left) FACS profiles of TNGA cultured in indicated conditions for 3 passages. The cells were cultured in Serum+LIF (SL) in presence of the $1 \mu \mathrm{M}$ MEK1/2 inhibitor PD0325901 (SLPD) or $3 \mu \mathrm{M}$ GSK3 $\beta$ inhibitor -CHIR99021 (SLCHIR) or in serum-free media - N2B27 with PD0325901, CHIR99021, and LIF (2i). (right) Nanog:GFP population median of TNGA $(n=4)$. (B) (left) FACS profiles of T $\beta$ c44Cre6 cultured in indicated conditions for 3 passages. $\mathrm{T} \beta \mathrm{C} 44 \mathrm{Cre} 6$ is a Nanog null cell line, where $\beta$-geo cassette is inserted into one allele and GFP into another allele of the Nanog gene. (right) Nanog:GFP population median of $\mathrm{T} \beta \mathrm{c} 44 \mathrm{Cre} 6(\mathrm{n}=3)$. (C) FACS profile of NANOG-iRFP protein in 
NiRFP2A cells cultured in indicated conditions for 3 passages. (D) RT-qPCR of pluripotency factors in indicated conditions (SL2i= SL+ PD0325901+CHIR99021). (E) RT-qPCR analysis of pre- mRNA of Nanog and Oct4. (F) (left)Western blot of NANOG, OCT4, and SOX2. (right) Relative NANOG levels as estimated by densitometry ( $\mathrm{n}=8)$. (G) Western blot of pERK1/2 and ERK1/2 at $0,1,4,8,12,16$, and 24 hrs after media change in indicated treatments. (H) Western blot of pERK1/2 and ERK1/2 in SLPD, SLCHIR, 2i, and SL2i after $8,12,16$, and $24 \mathrm{hrs}$ of culture relative to SL, where the cells in SL were harvested $24 \mathrm{hrs}$ after the media change. (I) (left)Western blot of pERK1/2 and ERK1/2 in $1 \mu \mathrm{M}$ PD and increasing concentrations of CHIR in serum-free N2B27 media. (right) Relative pERK1/2 levels $(\mathrm{n}=3)$. (J) (left)Western blot of pERK1/2 and ERK1/2 in $3 \mu \mathrm{M}$ CHIR and increasing concentrations of PD in serum-free N2B27 media. (right) Relative pERK1/2 levels ( $n=6)$. All error bars in the figure represent s.e.m. See also Figure S1.

Figure 2: FGF autocrine signaling pathway components are essential for Nanog autoregulation. (A) (left) Schematic depiction of Tamoxifen (OHT) inducible TNERT cell line. (Middle) FACS profile of TNERT treated with OHT (red) or no OHT (blue). (Right) Nanog:GFP population median of TNERT (n=3). (B) (left) Schematic of NsGFPDiN cells reporting NANOG-GFP fusion protein and carrying a Doxycycline- inducible FaNANOG transgene. (Middle) FACS profiles of NsGFPDiN after $48 \mathrm{hrs}$ with Doxycycline (red) or no Doxycycline (blue) treatment. (Right) Nanog:GFP population median of NsGFPDiN (n=3). (C) FACS profiles of TNERT, NsGFPDiN, and TDiN treated with $2 \mu \mathrm{M}$ SU5402, with OHT/Doxycycline (red) or no OHT/Doxycycline (blue). (D) Heat map representing transcript levels (FPKM) of Fgfbpl from 8-cell to blastocyst stage analyzed from the single-cell sequencing data. (E) Schematic depiction of TNERTFgfr1-/-, TNERTFgfr2-/, TNERTFgf4-/, and TNERTFgfbp1-/- cell lines, which are derivatives of TNERT where Fgfrl, Fgfr2, Fgf4, and Fgfbpl are knocked out respectively. (F) FACS profiles of TNERT, TNERTFgfr1-/-, TNERTFgfr2-/-, TNERTFgf4-/-, and TNERTFgfbp1-/- cells, treated with OHT (red) or no OHT (blue). All error bars in the figure represent s.e.m. See also Figure S2.

Figure 3: Nanog enhances expression of FGF autocrine signaling pathway components. (A) RT-qPCR showing relative transcript levels after $0,0.5,1,2,4,8,12$ and $18 \mathrm{hrs}$ OHT treatment in TNERT $(n=3)$. (B) RT-qPCR of relative levels of pre- mRNA at the above indicated time points after OHT treatment in TNERT $(n=3)$. (C) ChIP analysis of NANOG on 
Fgf4, Fgfbp1, Fgfrl, Fgfr2, and Nanog genes in E14Tg2a cells cultured in SL or SLPD for $48 \mathrm{hrs}(\mathrm{n}=4)$. (D) ChIP analysis of NANOG on promotors of above- indicated loci in EDiN cells cultured in Doxycycline (red) or no Doxycycline (blue) for 48 hrs (n=3). (E) Western blot of FGFR1, FGFR2, and pERK1/2 in TNERT after $18 \mathrm{hrs}$ treatment with (red) or no OHT (blue) (n=3). (F) FACS analysis of FGFR2 on the cell surface of TNERT treated with (red) or no OHT (blue) (n=3). (G-H) ELISA-based relative quantification of FGF4 (G) and FGFBP1 $(\mathrm{H})$ in conditioned media from TNERT treated with or no OHT $(n=3)$. (I) Schematic of conditioned media experiment. (J) FACS analysis of T $\beta$ c $44 \mathrm{Cre} 6$ cell line in conditioned media collected from TNERT treated with OHT after 0, 18, 24, and 48 hrs (K) (left) FACS analysis of TNERTZfp281-/- cells treated with (red) or with no OHT (blue) treatment. (right) Nanog:GFP population median of TNERTZfp281-/- (n=3). (L) FACS analysis of T $\beta$ c44Cre6 cell line in conditioned media from, TNERT+OHT 0 hrs, TNERTFGF4-/-, T $\beta$ c44Cre6 48 hrs, E14Tg2a- FGF4-OE (overexpression) 48 hrs, TNERT+OHT 48 hrs and 50ng/ml FGF4. All error bars in the figure represent s.e.m. See also Figure S3.

Figure 4: NANOG-induced FGFR2 triggers autoregulation predominately in the ES cell population with higher Nanog expression. (A) (top) FACS profile of TNERT, the position of the gates indicates the 10\% low-Nanog:GFP (LN) and 10\% high-Nanog:GFP (HN) population sorted for culture. (bottom left) FACS profiles of LN and HN after $18 \mathrm{hrs}$ culture in SL. LN (dark green), HN (dark maroon) in SL, and LN (light green), HN (light maroon) in SL+ OHT. (bottom right) Nanog:GFP population median of TNERT (n=3). (B) FACS profile of E14Tg2a cultured in SL or SLPD for $48 \mathrm{hrs}$ and co- immunostained with anti-NANOG and anti-FGFR1 or anti-FGFR2 antibodies. r-values represent the average of 3 independent experiments $(n=3)$. (C) (left) FACS profile of E14Tg2a immunostained with anti-NANOG and anti-FGFR2 antibody, the gates mark the 10\% low-NANOG (LN) and 10\% highNANOG (HN) population. (right) Histogram depicting the FGFR2 expression profiles in the gated LN and HN cell population ( $n=3$ ). (D-E) Schematic representation of TNERTNBR1-/(D) and TNERTNBR2-/- (E) cells, in which NANOG binding sequences at $+1.4 \mathrm{~kb}$ (NBR1) and $-0.2 \mathrm{~kb}$ (NBR2) are deleted respectively. (F) (Top) FACS profiles of TNERT, TNERTNBR1-/-, and TNERTNBR2-/- with (red) or no OHT treatment (blue). (bottom) Nanog:GFP population median of TNERT, TNERTNBR1-/- and TNERTNBR2-/- with or no OHT treatment. (G) A cartoon depicting Nanog autoregulation in Nanog-high cells. The Nanog-high cells secrete more FGF4 and FGFBP1. They contain higher levels of FGFR2 on 
the surface and hence more sensitive to the FGF ligand triggering a stronger FGF signaling. The increased pERK1/2 in these cells recruit NONO to the Nanog locus and represses Nanog transcription. The Nanog-low cells secrete very little FGF4 and FGFBP1 and present fewer FGFR2 on their surface and less sensitive to FGF signaling. The pERK1/2 levels in Nanoglow cells are insufficient to execute Nanog autoregulation. All error bars in the figure represent s.e.m. See also Figure S4.

Figure 5: ERK1/2 interacts and recruits NONO to repress Nanog transcription. (A) Schematic of TNERTNono-/-cell line; a derivative of TNERT in which Nono is knocked out. (B) FACS profile of TNERTNono-/- treated with or no OHT (n=3). (C) Western blot of pERK1/2 and ERK1/2 in TNERT and TNERTNono-/- cells treated with or no OHT $(n=3)$. (D) Immunoprecipitation analysis showing interactions between ERK1/2 and NONO in the presence or absence of Nanog induction by Doxycycline in TDiN cells. (E) (left) Western blot of pERK1/2 and ERK1/2 in E14Tg2a cells treated with PD or FGF4. (right) Relative levels of pERK1/2 in E14Tg2a cells treated with PD or FGF4 $(n=4)$. (F) Schematic representation of Nanog locus comprising the -6.0 to $+2 \mathrm{~kb}$ region. The vertical bars represent relative positions of primer pairs used for ChiP-qPCR analysis. S1-S6 are located upstream of the TSS, S7 primer pair is located around TSS, S8 and S9 are located downstream in the first intron. (G-K) ChIP-qPCR analysis of pERK1/2 (G), NONO (H), Pol2 (I), H3K4me3 (J) and H3K27me3 (K) on Nanog 5' region in E14Tg2a cells (blue), treated with FGF4 (green) and with PD (pink) (n=3). (L) Cycloheximide chase assay of NANOG in SL, SLPD, and SLFGF4 in E14Tg2a cells. (M) A cartoon illustrating the repression of Nanog by FGF signaling and derepression of Nanog in absence of Fgf signaling. The FGF4 activates the Fgf signaling cascade, results in phosphorylation of ERK1/2. pERK1/2 interacts and recruits NONO to Nanog promoter and represses transcription of Nanog. pERK1/2 also affects the stability of the NANOG. In absence of FGF4, the pERK1/2 levels decrease resulting in enhanced stability of NANOG and transcription of Nanog locus by NANOG and other pluripotency factors resulting in derepression of Nanog locus. All error bars represent s.e.m. See also Figure S5.

Figure 6: FGF autocrine signaling regulates Nanog heterogeneity and monoallelic expression. (A) Nanog:GFP fluorescence in TNGA cultured on gelatin or feeders in SL, SLPD, SLFGF4, and $2 \mathrm{i}(\mathrm{n}=3)$. Scale bars represent $75 \mu \mathrm{M}$. (B) Immunofluorescence of 
NANOG and OCT4 in E14Tg2a cells cultured on gelatin or feeders in SL, SLPD, and SLFGF4. Areas are marked to highlight the loss of NANOG. Scale bars represent $75 \mu \mathrm{M}$. (C) Immunofluorescence of NANOG and OCT4 in E14Tg2a, Fgfr2-/- ESCs, Fgf4-/- ESCs, and Fgf4-/- ESCs rescued with Ef1 $\alpha-F g f 4$ transgene. The marked area highlights the loss of NANOG. Scale bars represent $75 \mu \mathrm{M}$. (D) Schematic of OGNM cell line with Oct4-GFP transgenic reporter and T2A-mCherry reporting one of the Nanog alleles. (E) FACS profiles of OGNM cultured in SL, SLFGF4, SLSU5402, 2i, and SLPD on gelatin (top), on feeders (middle), and FSM (bottom). (F) Schematic of NsGiR cell line, with allele-specific NANOG protein reporters. One allele of Nanog reports as NANOGiRFP fusion protein and the other as NANOGsfGFP fusion protein. (G) FACS profiles of NsGiR cell line cultured in SL, SLCHIR, 2i, SLSU5402, SLFGF4, and SLPD. See also Figure S6.

Figure 7: A cartoon illustrating the role of FGF autocrine signaling in Nanog autoregulation, heterogeneity, and monoallelic expression. (a) A subpopulation of ES cells with high-Nanog induce expression of FGF signaling components- Fgf4, Fgfbpl, and Fgfr2. FGF4 and FGFBP1 are secreted out of the cells. The FGFR2 is retained on the cells leading to a high NANOG-high FGFR state. Higher FGFR activates FGF signaling in these cells resulting in enhanced pERK1/2. The pERK1/2 leads to destabilization of NANOG and recruits NONO to Nanog locus to repress its transcription resulting in a low/medium NANOG-high FGF/pERK state. The repression of Nanog and reduced NANOG levels diminishes activation of FGF signaling components, leading to a low NANOG-low FGFR state, with low pERK1/2. The diminished pERK1/2 releases the repression on the Nanog and enables stabilization of NANOG. This permits transcriptional activation of Nanog locus by pluripotency factors, increasing the expression of Nanog resulting in a low/medium NANOG-low FGF/pERK state. Unrestricted induction of Nanog in low pERK1/2 state results in enhanced activation of Nanog resulting in a high-Nanog expressing cells. (b) A cartoon showing heterogeneous expression of Nanog in ESCs cultured on gelatin. FGF4 and FGFBP1 are free to activate FGF autocrine/paracrine signaling to induce Nanog autoregulation resulting in Nanog heterogeneity. In feeders or FSM, FGF4 is either titrated out by FGFRs on feeder cells and extracellular matrix rendering it unavailable for triggering FGF autocrine signaling to induce Nanog autoregulation. In the absence of Nanog autoregulation, most of the cells continuously express Nanog resulting in loss of heterogeneity. (c) Low FGF autocrine signaling prevents pERK1/2 and repression of Nanog locus resulting in biallelic expression. An increase in FGF 
autocrine signaling activates ERK1/2 and leads to monoallelic expression. A further increase in FGF signaling results in complete repression of the Nanog locus.

\section{Methods:}

\section{Cell Culture}

The cell lines used in this study are listed in the resource table and their origin is depicted in supplemental flowchart 1. All the cells used in this study are derivatives of E14Tg2a ES cells (ATCC CRL1821). The cells were cultured as described earlier (Festuccia et al., 2012). 4Hydroxytamoxifen (4-OHT) (Cat\# H7904), Doxycycline (Cat\# D9891), and Cycloheximide (Cat\# 239764) were used at a concentration of $1 \mu \mathrm{g} / \mathrm{ml}, 1 \mu \mathrm{g} / \mathrm{ml}$, and $100 \mu \mathrm{g} / \mathrm{ml}$ respectively. The TNERT and its derivative cell lines were treated with 4-OHT for $18 \mathrm{hrs}$ except when indicated. TDiN, NsGFPDiN, and EDiN were treated with Doxycycline for 48 hrs unless indicated. CHIR99021 (CHIR) (Cat\# SML1046), PD0325901 (PD) (Cat\# PZ0162), and SU5402 (Cat\# SML0443) were used at $3 \mu \mathrm{M}, 1 \mu \mathrm{M}$, and $2 \mu \mathrm{M}$, respectively, except when indicated. FGF4 (Cat\# 7460-F4-025), FGFBP1 (Cat\# 1593-FB-025), Insulin (Cat\# RP-10908), EGF (Cat\# 01-107) and bFGF (Cat\# RP-8628) were used at 50ng/ml, 50ng/ml, 100ng/ml, $25 \mathrm{ng} / \mathrm{ml}$ and $10 \mathrm{ng} / \mathrm{ml}$ concentrations respectively. The cells were cultured in Serum+ LIF (SL), SL+ PD (SLPD), SL+CHIR (SLCHIR), SL+SU5402 (SLSU5402), SL + PD +CHIR (SL2i) and N2B27+LIF+PD+CHIR (2i) for at least 2 passages before treating with either 4OHT or Doxycycline.

The cells were cultured on cell culture dishes coated with $0.1 \%$ gelatin for all experiments. In experiments involving ESCs cultured on feeders, the feeder cells were seeded onto the culture dishes at least 48 hrs before seeding ESCs. To prepare feeder secrete matrix (FSM), feeder cells were seeded onto a culture dish and cultured for 4-5 days. The cells were lysed with $0.01 \%$ SDS for 30 mins followed by two washes with PBS for 30 mins each. Finally, the FSM was equilibrated with media for 30 mins. The conditioned media from the cells was collected after the specific treatments or indicated time points. The conditioned media was passed through a $0.22 \mu \mathrm{M}$ filter and added to T $\beta$ c 44 Cre 6 or TNERT cells. The cells were cultured in the conditioned media for 24 hrs before FACS analysis.

Generation of Knock-out cell lines using paired CRISPR constructs: pU6-iRFP (pU6- 
Cas9-T2A-iRFP-2A-PuroR) construct was engineered by replacing mCherry coding sequence with iRFP670-2A-PuroR cassette in pU6-(BbsI)-CBh-Cas9-T2A-mCherry plasmid (Addgene 64324) by Gibson assembly. For generating knock-out of a gene, two sgRNAs were designed with the expected cutting sites at least 30 bps apart to achieve deletion of at least $30 \mathrm{bps}$ or more. For genotyping of the deletions, a set of genotyping primers was designed outside the deletion region flanking the sgRNA pair. The sgRNAs were designed using the UCSC genome browser and Deskgen or Benchling. The sequences of the sgRNAs and the genotyping primers are detailed in Supplemental data table 1. All sgRNAs were cloned into pU6-Cas9-T2A-iRFP-2A- PuroR plasmids. To generate a paired sgRNA construct, the U6SgRNA cassette from one plasmid containing the sgRNA was amplified and Gibson assembled into the $\mathrm{XbaI}$ site of the plasmid containing the other sgRNA pair of the pair. Around $1 \mu \mathrm{g}$ of paired sgRNA CRISPR plasmid was nucleofected in 1 million cells. The transfected cells were sorted by FACS for iRFP expression and cultured to obtain clones. The clones were genotyped by PCR using respective primer sets to identify the heterozygous and homozygous clones. The sequence of the derivation of cell lines is described in supplemental Figure 7.

Generation of Knock-in cell lines: A sgRNA encompassing the stop codon of Nanog was cloned into pU6-iRFP and co-transfected with the targeting vectors. Nanog-2A- mCherry targeting vector (Addgene 59995) was used for generating the OGNM cell line. The 2AmCherry cassette was replaced with sfGFP or iRFP sequences by Gibson assembly to generate Nanog sfGFP fusion or Nanog iRFP670 fusion targeting vector respectively. Around $3 \mu \mathrm{g}$ plasmid (targeting vector and CRISPR plasmid) were nucleofected in 3 million E14Tg2a cells. The cells were selected against G418. The derivation of cell lines is described in Supplemental Figure 7.

\section{Real-time PCR analysis:}

The RNA was extracted with TRIZOL reagent and quantified using Nanodrop2000 spectrophotometer (Thermo Fisher Scientific). One microgram of total RNA was reversed transcribed into cDNA by using superscript III. All real-time PCR was carried out with Power SYBR Green PCR master mix on the ABI prism 7900 HT sequence detection system $(\mathrm{ABI})$ as per the manufacturer's instructions. GAPDH was used as an internal control or normalizer. The data was analyzed by SDS 2.2 software provided with the instrument. The 
primers used for real-time PCR are given in the supplemental data table 1.

Western blot analysis: The cells were harvested by using RIPA buffer with $25 \mathrm{mM}$ Tris $\mathrm{HCl}$ $(\mathrm{pH} 8.0), 150 \mathrm{mM} \mathrm{NaCl}, 1 \% \mathrm{NP}-40,0.5 \%$ Sodium deoxycholate, $0.1 \%$ SDS and Complete Protease Inhibitor Cocktail Tablets (Cat\# 11873580001). The protein samples were resolved by $4-20 \%$ gradient SDS-PAGE and electroblotted on to polyvinylidene difluoride (PVDF) membrane. The blot was blocked with 3\% Blotto (Cat\# SC-2324) for an hour and incubated overnight with a primary antibody at $4^{\circ} \mathrm{C}$. Blots were washed thrice with TBST and hybridized with secondary antibody and the blots were visualized using enhanced chemiluminescence (ECL)detection kit. Western blot quantifications were performed using Image lab (Bio-rad).

\section{Chromatin Immunoprecipitation (ChIP):}

Cells were fixed by adding $270 \mu \mathrm{L}$ of $37 \%$ formaldehyde into $10 \mathrm{ml}$ of media and incubated for 10 minutes at $37^{0} \mathrm{C}$ to crosslink the chromatin. Cells were washed twice with cold PBS containing protease inhibitors. Cells were scraped and harvested by centrifugation. The cell pellet was dissolved in $200 \mu \mathrm{L}$ of SDS Lysis Buffer (1\% SDS, $10 \mathrm{mM}$ EDTA, and $50 \mathrm{mM}$ Tris, $\mathrm{pH}$ 8.0) containing protease inhibitors (per $10^{6}$ cells) and incubated on ice for $10 \mathrm{~min}$. The 25 cycles of sonication were used to shear DNA between 200 to1000 base pairs. The sample was centrifuged at $13,000 \mathrm{rpm}$ for $10 \mathrm{~min}\left(\right.$ at $4{ }^{\circ} \mathrm{C}$ ). The supernatant was diluted by adding $1800 \mu \mathrm{l}$ ChIP Dilution Buffer (1.1\% Triton X- 100, $1.2 \mathrm{mM}$ EDTA, $16.7 \mathrm{mM}$ Tris$\mathrm{HCl}, \mathrm{pH} 8.0,167 \mathrm{mM} \mathrm{NaCl}$ with protease inhibitors). The $1 \%$ input was aliquoted from the supernatant. To reduce nonspecific background, diluted cell supernatant was preabsorbed for one hour at $4^{\circ} \mathrm{C}$ with protein $\mathrm{A} / \mathrm{G}$ magnetic beads (Cat\# 88803). The supernatant fraction was incubated overnight at $4^{\circ} \mathrm{C}$ with appropriate antibody and protein $\mathrm{A} / \mathrm{G}$ magnetic beads were blocked with $4 \%$ BSA, $2 \mu \mathrm{g}$ salmon sperm DNA. The next day, pre-blocked beads were mixed with the sample and incubated for 1 hour to capture the antibodies. The supernatant was discarded and washed in the given order with $1 \mathrm{~mL}$ of each of the buffers - Low Salt Wash Buffer (0.1\% SDS, 1\% Triton X-100, 2 mM EDTA, $20 \mathrm{mM}$ Tris-HCl, pH 8.0, $150 \mathrm{mM}$ $\mathrm{NaCl})$, High Salt Wash Buffer (0.1\% SDS, 1\% Triton X-100, 2 mM EDTA, 20 mM Tris$\mathrm{HCl}, \mathrm{pH}$ 8.0, $500 \mathrm{mM} \mathrm{NaCl}$ ), LiCl Wash Buffer (0.25 M LiCl, 1\% IGEPAL-CA630, 1\% deoxycholic acid, $1 \mathrm{mM}$ EDTA, $10 \mathrm{mM}$ Tris, pH 8.0.), and TE buffer. DNA was eluted with elution buffer (1\%SDS, 0.1M NaHCO3). The sample input and the ChIP chromatin were 
reverse crosslinked with $20 \mu \mathrm{L}$ of $5 \mathrm{M} \mathrm{NaCl}$ by heating at $65^{\circ} \mathrm{C}$ for 4 hours. Followed by one hour at $45^{\circ} \mathrm{C}$ with $10 \mu \mathrm{L}$ of $0.5 \mathrm{M}$ EDTA, $20 \mu \mathrm{L} 1 \mathrm{M}$ Tris- $\mathrm{HCl}$, $\mathrm{pH} 6.5$, and $2 \mu \mathrm{L}$ of 10 $\mathrm{mg} / \mathrm{mL}$ Proteinase K. Finally, DNA was eluted in $50 \mu \mathrm{L}$ water using a minEleute PCR purification kit (Cat\# 28006). Then $1 \mu \mathrm{L}$ of sample and input was used for qPCR analysis. The primers used for qPCR analysis were listed in supplemental data table 1.

Co-Immunoprecipitation in ES cells: 10-12 million ES cells were harvested by trypsinization, washed twice with cold PBS, and resuspended in $800 \mu \mathrm{l}$ of CoIP Lysis Buffer (50 mM Tris- $\mathrm{HCl}, \mathrm{pH}$ 67.5; $350 \mathrm{mM} \mathrm{NaCl}, 0.7 \%$ NP40, EDTA $0.1 \mathrm{mM}, 20 \%$ (v/v) glycerol, and protease inhibitor cocktail). The cell lysate was mixed with protein A/G magnetic beads (Cat\# 88803) for 1 hour at $4^{\circ} \mathrm{C}$ for pre-clearing the background. Then $5 \%$ input was aliquoted and the remaining supernatant was incubated overnight with appropriate primary antibody. The protein A/G magnetic beads were blocked overnight at $4^{\circ} \mathrm{C}$ with $200 \mu \mathrm{l}$ of CoIP Lysis buffer containing $4 \% \mathrm{BSA}$. The next day, the beads were transferred to the primary antibody incubated tubes and incubated for one hour at $4^{\circ} \mathrm{C}$. The bead was washed three times with ice-cold TBS150 (50mM Tris, $150 \mathrm{mM} \mathrm{NaCl})$ and the protein was eluted with $2 \mathrm{X}$ sample buffer (125 mM Tris-HCl, pH 6.8, 4\% SDS, 20\% (v/v) glycerol, 0.004\% bromophenol blue), by boiling for $5 \mathrm{~min}$. The western was done for sample and input and the interaction was analyzed.

Immunocytochemistry: The cells were cultured in 24 well dishes and fixed at $70 \%$ confluency in 3.7\% formaldehyde diluted in PBS for 15 mins at RT. After 3 washes with PBS, the cells were permeabilized and blocked with PBS containing 0.5\% BSA and $0.3 \%$ TritonX100 for 1 hour at room temperature. The cells were hybridized with primary antibody (1:100 dilution) in PBS containing $0.5 \% \mathrm{BSA}$ at $4^{\circ} \mathrm{C}$ overnight in a humidified chamber. The cells were washed three times with PBS and hybridized to appropriate secondary antibody at 1:1000 dilution room temperature for 1hour. The nuclei were stained with DAPI in 1X PBS for $20 \mathrm{~min}$ at room temperature. The cells were washed thrice with PBS. The cells were layered with $100 \mu 1$ of the mixture of PBS and Glycerol (1:1) and the images were acquired on the ZEISS Axio observer microscope and analyzed using ImageJ software.

\section{ELISA Assay:}

The condition media from the cell lines was collected at the respective time points. $100 \mu 1$ of 
the media was coated per well of 96 well of ELISA plate by incubating overnight at $4^{\circ} \mathrm{C}$. The wells were washed thrice with PBS containing 0.05\% Tween-20 and blocked with PBS containing $2 \% \mathrm{BSA}$ for one hour at room temperature. The wells were washed once with PBS and incubated with the appropriate primary antibody (1:100) for one hour. Washed thrice with PBST, appropriate HRP-labeled secondary antibody was hybridized for one hour at room temperature. The wells were washed thrice with PBST and incubated in substrate solution OPD (o-phenylenediamine dihydrochloride) (Cat\# P8287) $3 \mathrm{mg} / \mathrm{ml}$ with $6 \mu \mathrm{l} / \mathrm{ml} \mathrm{H}_{2} \mathrm{O}_{2}$ ) for 30 min in dark. The reaction was stopped by using $2 \mathrm{~N} \mathrm{H}_{2} \mathrm{SO}_{4}$. The absorbance was measured at $492 \mathrm{~nm}$ in Power wave XS2 (Bio Tek instruments)

\section{FACS analysis:}

Reporter cells: Cells were trypsinized and collected by spinning at $800 \mathrm{rpm}$ for $5 \mathrm{~min}$. The media was removed and cells were resuspended in $300 \mu$ l of PBS containing $2 \%$ FBS at $10^{6}$ cells/ml. The samples were analyzed in the Gallios flow cytometer (Beckman Coulter) or Fortessa flow cytometer (BD Biosciences). Sorting was performed on a MoFlo-XDP cell sorter (Beckman Coulter).

Immunostained cells: Cells were harvested by treatment with $0.5 \mathrm{mM}$ EDTA and resuspended into single cells. The cells were fixed in PBS with $4 \%$ paraformaldehyde (PFA) for $20 \mathrm{~min}$ at room temperature. Cells were washed twice with cold PBS and incubated with methanol for $30 \mathrm{~min}$ for permeabilization. In the case of experiments involving analysis of FGFRs on the cell surface, the permeabilization step was excluded. Then cells were blocked with PBS containing 0.5\% BSA for $60 \mathrm{~min}$ at room temperature. The cells were washed and hybridized to the appropriate primary antibody at $4^{\circ} \mathrm{C}$ overnight. The cells were washed thrice with PBS and hybridized to the appropriate secondary antibody in PBS containing $0.5 \%$ BSA at1:1000 dilution for one hour at room temperature. The cells were washed thrice with PBS and the fluorescence profiles were acquired in the Gallios FACS analyzer (Beckman Coulter). All the FACS data were analyzed using FlowJo software (BD Biosciences).

\section{Statistical analysis and reproducibility:}

Statistical analysis was done by using a two-tailed paired or unpaired student t-test. The representation of data is in the form of means+/-SEM. The mean was calculated for more than 
bioRxiv preprint doi: https://doi.org/10.1101/2021.06.28.450121. this version posted June 29, 2021. The copyright holder for this preprint (which was not certified by peer review) is the author/funder, who has granted bioRxiv a license to display the preprint in perpetuity. It is made available under aCC-BY-NC-ND 4.0 International license.

three independent experiments $P$ value $<0.05$ is considered as statistically significant. * represents $\mathrm{P}<0.05$, ** represents $\mathrm{P}<0.001$, *** represents $\mathrm{P}<0.0001$, and ***** represents $\mathrm{P}<0.00001$.

\section{REFERENCES}

Auciello, G., Cunningham, D.L., Tatar, T., Heath, J.K., and Rappoport, J.Z. (2013). Regulation of fibroblast growth factor receptor signalling and trafficking by Src and Eps8. Journal of cell science 126, 613-624.

Bessonnard, S., De Mot, L., Gonze, D., Barriol, M., Dennis, C., Goldbeter, A., Dupont, G., and Chazaud, C. (2014). Gata6, Nanog and Erk signaling control cell fate in the inner cell mass through a tristable regulatory network. Development 141, 3637-3648.

Brumbaugh, J., Russell, J.D., Yu, P., Westphall, M.S., Coon, J.J., and Thomson, J.A. (2014). NANOG is multiply phosphorylated and directly modified by ERK2 and CDK1 in vitro. Stem cell reports $2,18-25$.

Chambers, I., Colby, D., Robertson, M., Nichols, J., Lee, S., Tweedie, S., and Smith, A. (2003). Functional expression cloning of Nanog, a pluripotency sustaining factor in embryonic stem cells. Cell 113, 643-655.

Chambers, I., Silva, J., Colby, D., Nichols, J., Nijmeijer, B., Robertson, M., Vrana, J., Jones, K., Grotewold, L., and Smith, A. (2007). Nanog safeguards pluripotency and mediates germline development. Nature 450, 1230-1234.

Chen, X., Xu, H., Yuan, P., Fang, F., Huss, M., Vega, V.B., Wong, E., Orlov, Y.L., Zhang, W., and Jiang, J. (2008). Integration of external signaling pathways with the core transcriptional network in embryonic stem cells. Cell 133, 1106-1117.

Davies, O.R., Lin, C.-Y., Radzisheuskaya, A., Zhou, X., Taube, J., Blin, G., Waterhouse, A., Smith, A.J., and Lowell, S. (2013). Tcf15 primes pluripotent cells for differentiation. Cell reports 3, 472-484.

Faddah, D.A., Wang, H., Cheng, A.W., Katz, Y., Buganim, Y., and Jaenisch, R. (2013). Single-cell analysis reveals that expression of nanog is biallelic and equally variable as that of other pluripotency factors in mouse ESCs. Cell stem cell 13, 23-29.

Festuccia, N., Osorno, R., Halbritter, F., Karwacki-Neisius, V., Navarro, P., Colby, D., Wong, F., Yates, A., Tomlinson, S.R., and Chambers, I. (2012). Esrrb is a direct Nanog target gene that can substitute for Nanog function in pluripotent cells. Cell stem cell 11, 477-490.

Fidalgo, M., Faiola, F., Pereira, C.-F., Ding, J., Saunders, A., Gingold, J., Schaniel, C., Lemischka, I.R., Silva, J.C., and Wang, J. (2012). Zfp281 mediates Nanog autorepression through recruitment of the NuRD complex and inhibits somatic cell reprogramming. Proceedings of the National Academy of Sciences 109, 16202-16207.

Fidalgo, M., Shekar, P.C., Ang, Y.S., Fujiwara, Y., Orkin, S.H., and Wang, J. (2011). Zfp281 functions as a transcriptional repressor for pluripotency of mouse embryonic stem cells. Stem cells 29, 1705-1716.

Filipczyk, A., Gkatzis, K., Fu, J., Hoppe, P.S., Lickert, H., Anastassiadis, K., and Schroeder, T. (2013). Biallelic expression of nanog protein in mouse embryonic stem cells. Cell stem cell $13,12-13$.

Francavilla, C., Rigbolt, K.T., Emdal, K.B., Carraro, G., Vernet, E., Bekker-Jensen, D.B., Streicher, W., Wikström, M., Sundström, M., and Bellusci, S. (2013). Functional proteomics defines the molecular switch underlying FGF receptor trafficking and cellular outputs. 
Molecular cell 51, 707-722.

Frankenberg, S., Gerbe, F., Bessonnard, S., Belville, C., Pouchin, P., Bardot, O., and Chazaud, C. (2011). Primitive endoderm differentiates via a three-step mechanism involving Nanog and RTK signaling. Developmental cell 21, 1005-1013.

Galanternik, M.V., Kramer, K.L., and Piotrowski, T. (2015). Heparan sulfate proteoglycans regulate Fgf signaling and cell polarity during collective cell migration. Cell reports 10, 414428.

Hamazaki, T., Kehoe, S.M., Nakano, T., and Terada, N. (2006). The Grb2/Mek pathway represses Nanog in murine embryonic stem cells. Molecular and cellular biology 26, 75397549.

Hayashi, K., de Sousa Lopes, S.M.C., Tang, F., and Surani, M.A. (2008). Dynamic equilibrium and heterogeneity of mouse pluripotent stem cells with distinct functional and epigenetic states. Cell stem cell 3, 391-401.

Jin, J., Liu, J., Chen, C., Liu, Z., Jiang, C., Chu, H., Pan, W., Wang, X., Zhang, L., and Li, B. (2016). The deubiquitinase USP21 maintains the stemness of mouse embryonic stem cells via stabilization of Nanog. Nature communications 7, 1-15.

Kalmar, T., Lim, C., Hayward, P., Munoz-Descalzo, S., Nichols, J., Garcia-Ojalvo, J., and Arias, A.M. (2009). Regulated fluctuations in nanog expression mediate cell fate decisions in embryonic stem cells. PLoS Biol 7, e1000149.

Kang, M., Garg, V., and Hadjantonakis, A.-K. (2017). Lineage establishment and progression within the inner cell mass of the mouse blastocyst requires FGFR1 and FGFR2. Developmental cell 41, 496-510. e495.

Karwacki-Neisius, V., Göke, J., Osorno, R., Halbritter, F., Ng, J.H., Weiße, A.Y., Wong, F.C., Gagliardi, A., Mullin, N.P., and Festuccia, N. (2013). Reduced Oct4 expression directs a robust pluripotent state with distinct signaling activity and increased enhancer occupancy by Oct4 and Nanog. Cell stem cell 12, 531-545.

Kim, S.-H., Kim, M.O., Cho, Y.-Y., Yao, K., Kim, D.J., Jeong, C.-H., Yu, D.H., Bae, K.B., Cho, E.J., and Jung, S.K. (2014). ERK1 phosphorylates Nanog to regulate protein stability and stem cell self-renewal. Stem cell research 13, 1-11.

Kunath, T., Saba-El-Leil, M.K., Almousailleakh, M., Wray, J., Meloche, S., and Smith, A. (2007). FGF stimulation of the Erk1/2 signalling cascade triggers transition of pluripotent embryonic stem cells from self-renewal to lineage commitment. Development 134, 28952902.

Lakatos, D., Travis, E.D., Pierson, K.E., Vivian, J.L., and Czirok, A. (2014). Autocrine FGF feedback can establish distinct states of Nanog expression in pluripotent stem cells: a computational analysis. BMC Systems Biology 8, 1-15.

Lanner, F., and Rossant, J. (2010). The role of FGF/Erk signaling in pluripotent cells. Development 137, 3351-3360.

Lee, S.T., Im Yun, J., Jo, Y.S., Mochizuki, M., van der Vlies, A.J., Kontos, S., Ihm, J.E., Lim, J.M., and Hubbell, J.A. (2010). Engineering integrin signaling for promoting embryonic stem cell self-renewal in a precisely defined niche. Biomaterials 31, 1219-1226.

Loh, Y.-H., Wu, Q., Chew, J.-L., Vega, V.B., Zhang, W., Chen, X., Bourque, G., George, J., Leong, B., and Liu, J. (2006). The Oct4 and Nanog transcription network regulates pluripotency in mouse embryonic stem cells. Nature genetics 38, 431-440.

Ma, C., Karwacki-Neisius, V., Tang, H., Li, W., Shi, Z., Hu, H., Xu, W., Wang, Z., Kong, L., and Lv, R. (2016). Nono, a bivalent domain factor, regulates Erk signaling and mouse embryonic stem cell pluripotency. Cell reports 17, 997-1007.

Marks, H., Kalkan, T., Menafra, R., Denissov, S., Jones, K., Hofemeister, H., Nichols, J., Kranz, A., Stewart, A.F., and Smith, A. (2012). The transcriptional and epigenomic foundations of ground state pluripotency. Cell 149, 590-604. 
bioRxiv preprint doi: https://doi.org/10.1101/2021.06.28.450121; this version posted June 29, 2021. The copyright holder for this preprint (which was not certified by peer review) is the author/funder, who has granted bioRxiv a license to display the preprint in perpetuity. It is made available under aCC-BY-NC-ND 4.0 International license.

Messerschmidt, D.M., and Kemler, R. (2010). Nanog is required for primitive endoderm formation through a non-cell autonomous mechanism. Developmental biology 344, 129-137. Mitsui, K., Tokuzawa, Y., Itoh, H., Segawa, K., Murakami, M., Takahashi, K., Maruyama, M., Maeda, M., and Yamanaka, S. (2003). The homeoprotein Nanog is required for maintenance of pluripotency in mouse epiblast and ES cells. Cell 113, 631-642.

Miyanari, Y., and Torres-Padilla, M.-E. (2012). Control of ground-state pluripotency by allelic regulation of Nanog. Nature 483, 470-473.

Molotkov, A., Mazot, P., Brewer, J.R., Cinalli, R.M., and Soriano, P. (2017). Distinct requirements for FGFR1 and FGFR2 in primitive endoderm development and exit from pluripotency. Developmental cell 41, 511-526. e514.

Mora-Castilla, S., Tejedo, J., Hmadcha, A., Cahuana, G.M., Martín, F., Soria, B., and Bedoya, F. (2010). Nitric oxide repression of Nanog promotes mouse embryonic stem cell differentiation. Cell Death \& Differentiation 17, 1025-1033.

Navarro, P., Festuccia, N., Colby, D., Gagliardi, A., Mullin, N.P., Zhang, W., KarwackiNeisius, V., Osorno, R., Kelly, D., and Robertson, M. (2012). OCT4/SOX2-independent Nanog autorepression modulates heterogeneous Nanog gene expression in mouse ES cells. The EMBO journal 31, 4547-4562.

Nichols, J., Silva, J., Roode, M., and Smith, A. (2009). Suppression of Erk signalling promotes ground state pluripotency in the mouse embryo. Development 136, 3215-3222.

Niwa, H., Ogawa, K., Shimosato, D., and Adachi, K. (2009). A parallel circuit of LIF signalling pathways maintains pluripotency of mouse ES cells. Nature 460, 118-122.

Ornitz, D.M., Xu, J., Colvin, J.S., McEwen, D.G., MacArthur, C.A., Coulier, F., Gao, G., and Goldfarb, M. (1996). Receptor specificity of the fibroblast growth factor family. Journal of Biological Chemistry 271, 15292-15297.

Park, S.-J., Shirahige, K., Ohsugi, M., and Nakai, K. (2015). DBTMEE: a database of transcriptome in mouse early embryos. Nucleic acids research 43, D771-D776.

Pereira, L., Yi, F., and Merrill, B.J. (2006). Repression of Nanog gene transcription by Tcf3 limits embryonic stem cell self-renewal. Molecular and cellular biology 26, 7479-7491.

Pokrass, M.J., Ryan, K.A., Xin, T., Pielstick, B., Timp, W., Greco, V., and Regot, S. (2020). Cell-cycle-dependent ERK signaling dynamics direct fate specification in the mammalian preimplantation embryo. Developmental Cell 55, 328-340. e325.

Simon, C.S., Rahman, S., Raina, D., Schröter, C., and Hadjantonakis, A.-K. (2020). Live Visualization of ERK Activity in the Mouse Blastocyst Reveals Lineage-Specific Signaling Dynamics. Developmental Cell 55, 341-353. e345.

Smith, A. (2013). Nanog heterogeneity: tilting at windmills? Cell stem cell 13, 6-7.

Tassi, E., Al-Attar, A., Aigner, A., Swift, M.R., McDonnell, K., Karavanov, A., and Wellstein, A. (2001). Enhancement of fibroblast growth factor (FGF) activity by an FGFbinding protein. Journal of Biological Chemistry 276, 40247-40253.

Tee, W.-W., Shen, S.S., Oksuz, O., Narendra, V., and Reinberg, D. (2014). Erk1/2 activity promotes chromatin features and RNAPII phosphorylation at developmental promoters in mouse ESCs. Cell 156, 678-690.

Torres-Padilla, M.-E., and Chambers, I. (2014). Transcription factor heterogeneity in pluripotent stem cells: a stochastic advantage. Development 141, 2173-2181.

Toyooka, Y., Shimosato, D., Murakami, K., Takahashi, K., and Niwa, H. (2008). Identification and characterization of subpopulations in undifferentiated ES cell culture. Development 135, 909-918.

van den Berg, D.L., Zhang, W., Yates, A., Engelen, E., Takacs, K., Bezstarosti, K., Demmers, J., Chambers, I., and Poot, R.A. (2008). Estrogen-related receptor beta interacts with Oct4 to positively regulate Nanog gene expression. Molecular and cellular biology 28, 5986-5995. 
bioRxiv preprint doi: https://doi.org/10.1101/2021.06.28.450121; this version posted June 29, 2021. The copyright holder for this preprint (which was not certified by peer review) is the author/funder, who has granted bioRxiv a license to display the preprint in perpetuity. It is made available under aCC-BY-NC-ND 4.0 International license.

Wray, J., Kalkan, T., and Smith, A.G. (2010). The ground state of pluripotency. Biochemical Society Transactions 38, 1027-1032.

Yun, M.-S., Kim, S.-E., Jeon, S.H., Lee, J.-S., and Choi, K.-Y. (2005). Both ERK and Wnt/ $\beta$ catenin pathways are involved in Wnt3a-induced proliferation. Journal of cell science 118 , 313-322.

Zhang, X., Ibrahimi, O.A., Olsen, S.K., Umemori, H., Mohammadi, M., and Ornitz, D.M. (2006). Receptor specificity of the fibroblast growth factor family: the complete mammalian FGF family. Journal of Biological Chemistry 281, 15694-15700. 
bioRxiv preprint doi: https://doi.org/10.1101/2021.06.28.450121: this version posted June 29, 2021. The copyright holder for this preprint Figurejely was not certified by peer review) is the author/funder, who has granted bioRxiv a license to display the preprint in perpetuity. It is
made available under aCC-BY-NC-ND 4.0 International license.

A

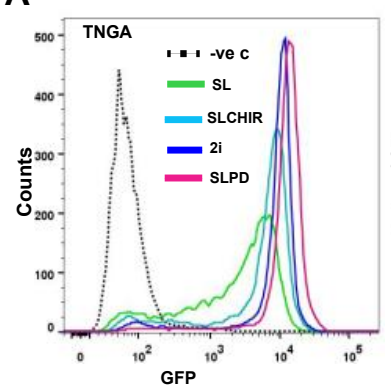

C

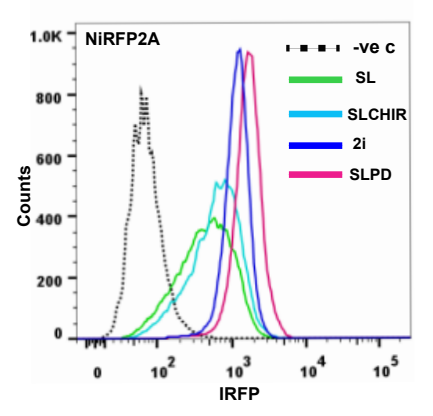

$\mathbf{F}$

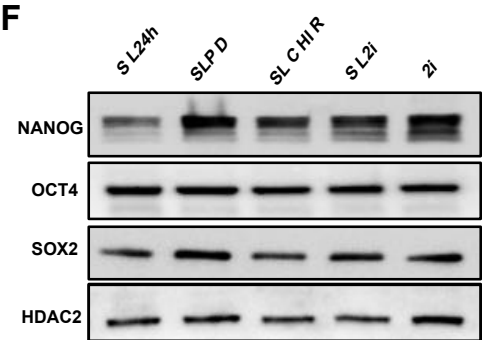

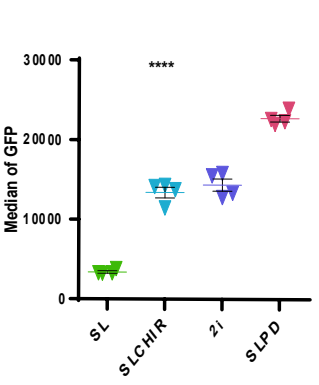

D

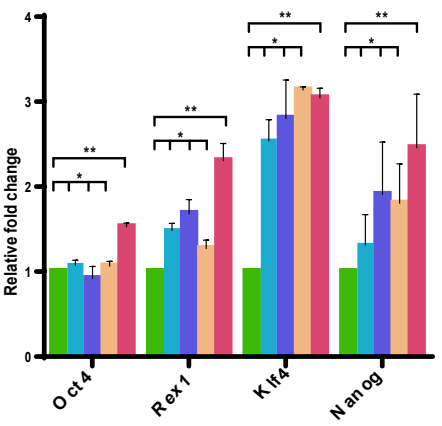

B

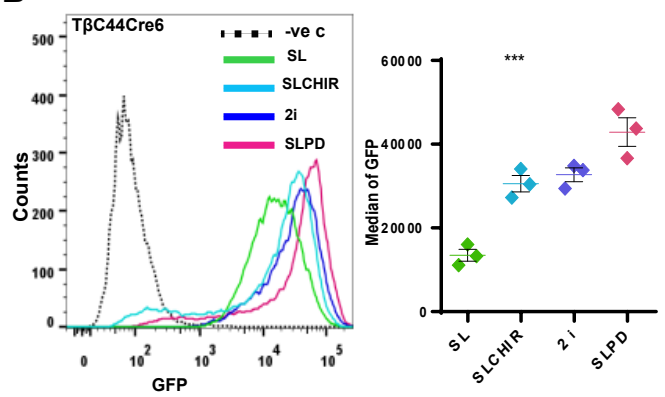

E

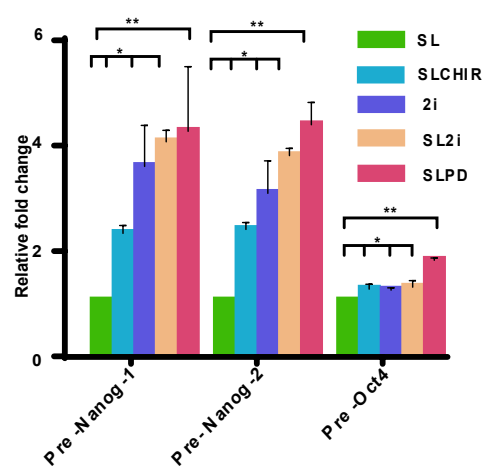

G

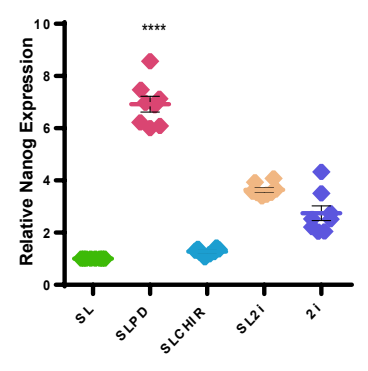

G $\quad$ Oh $\quad 1 \mathrm{~h} \quad 4 \mathrm{~h} \quad 8 \mathrm{~h} \quad 12 \mathrm{~h} \quad 16 \mathrm{~h} \quad 24 \mathrm{~h}$ p-ERK1/2 $=--=-=-\mathrm{sL}$ ЕRK $1 / 2====$ p-ERK1/2 $=$ SLPD ${ }_{\mathrm{ERK} 1 / 2}=\equiv= \pm=$ p-ERK $1 / 2=-\infty-\infty$ SLCHIR ${ }_{\mathrm{ERK} 1 / 2}=\geq==\geq=$ p-ERK1/2 $=-\ldots-\ldots-2 \mathrm{i}$ $\mathrm{ERK} 1 / 2^{\mathrm{E}}=== \pm==$ p-ERK1/2 $=-\ldots-m$ SL2i ${ }_{\mathrm{ERK} 1 / 2}= \pm== \pm=$

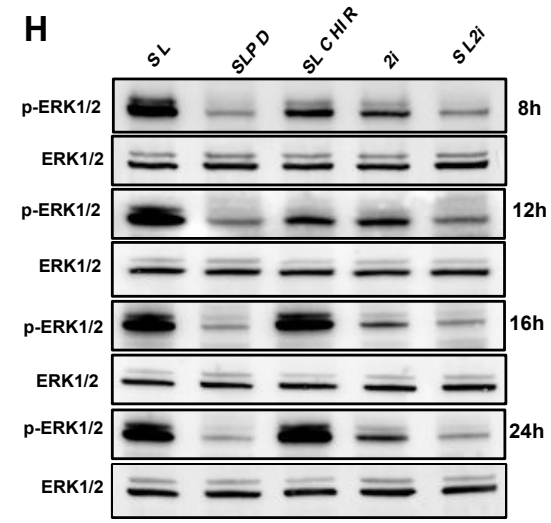

I
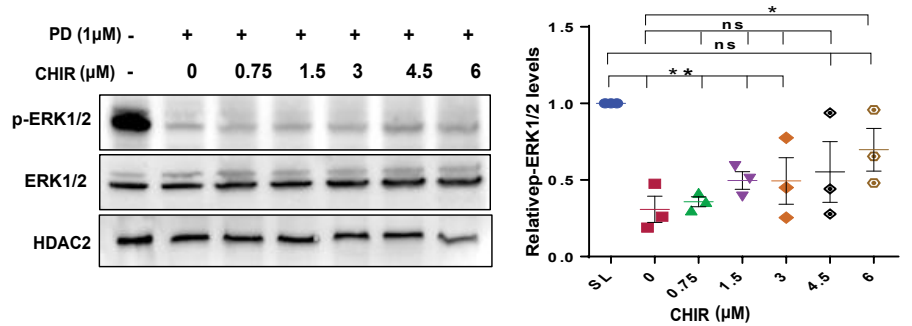

J
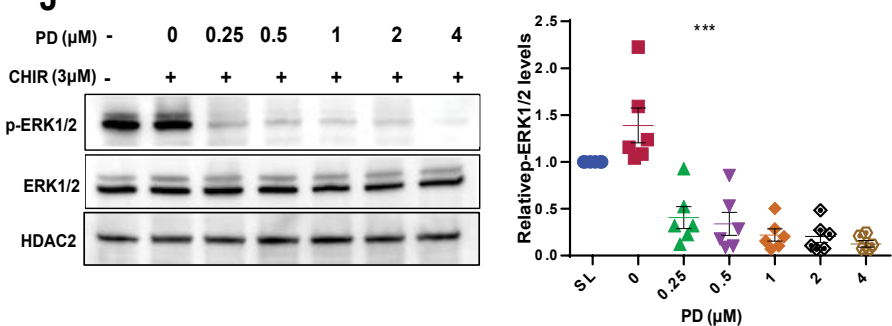
bioRxiv preprint doi: https://doi.org/10.1101/2021.06.28.450121; this version posted June 29,2021 . The copyright holder for this preprint Figuren was not certified by peer review) is the author/funder, who has granted bioRxiv a license to display the preprint in perpetuity. It is made available under aCC-BY-NC-ND 4.0 International license.

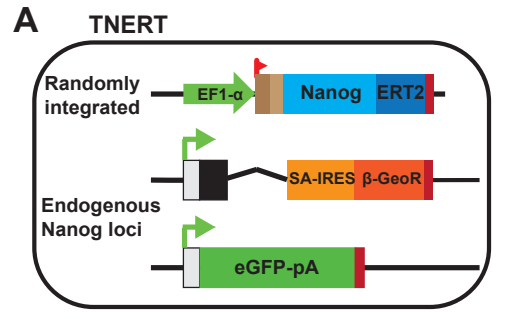

B

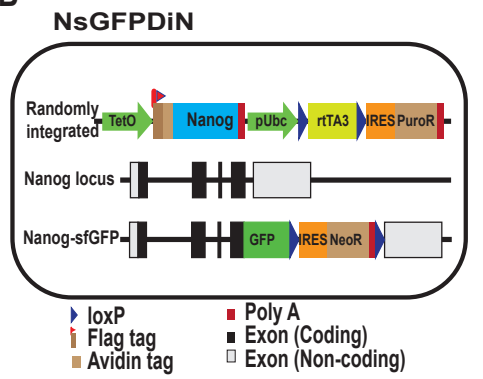

C
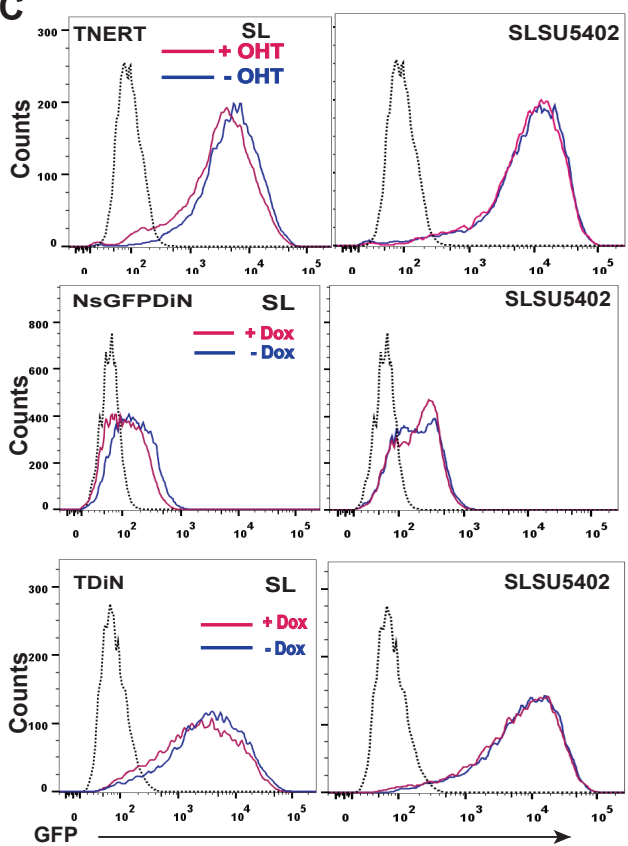

D

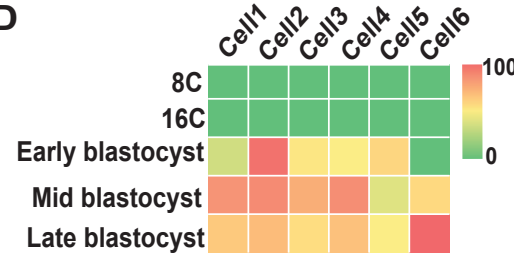

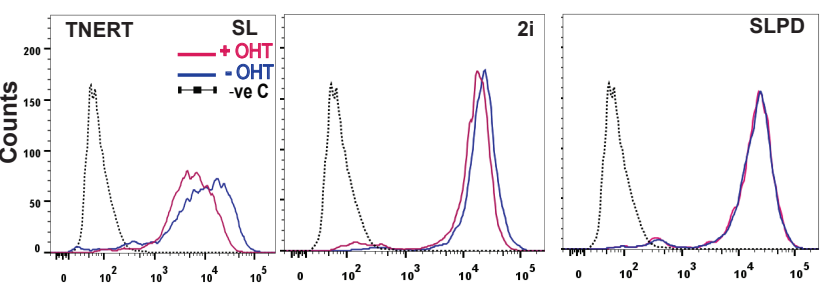
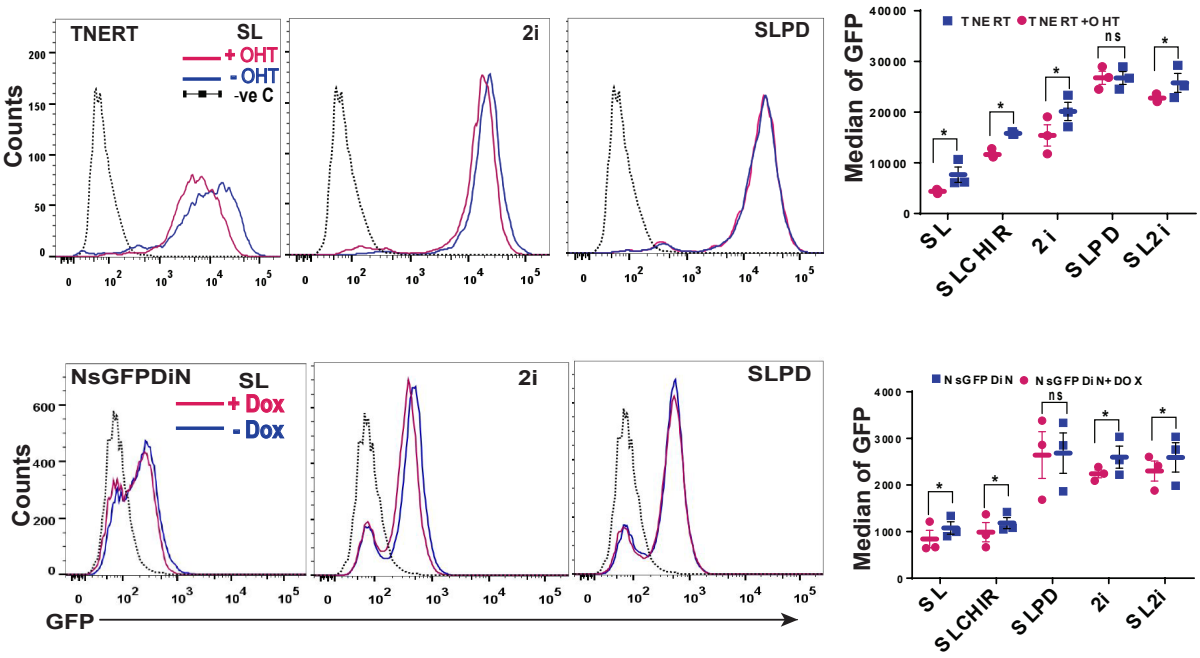

E

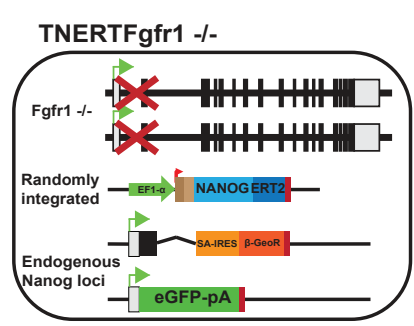

TNERTFgf4-/-

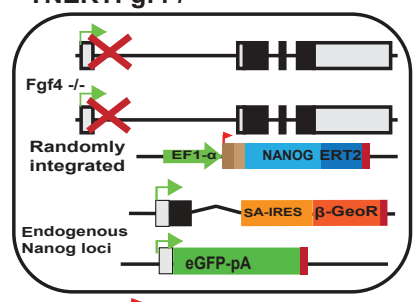

TNERTFgfr2-I-

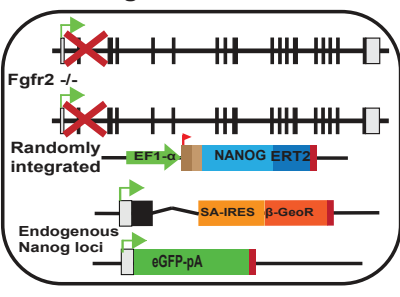

TNERTFgfbp 1-/

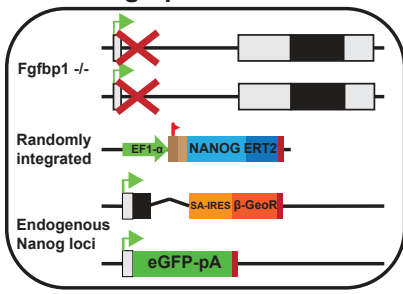

Flag tag $X$ Knockout $\square$ Avidin tag $\square$ Exon (Coding) $\square$ Poly A $\square$ Exon (Non-coding)
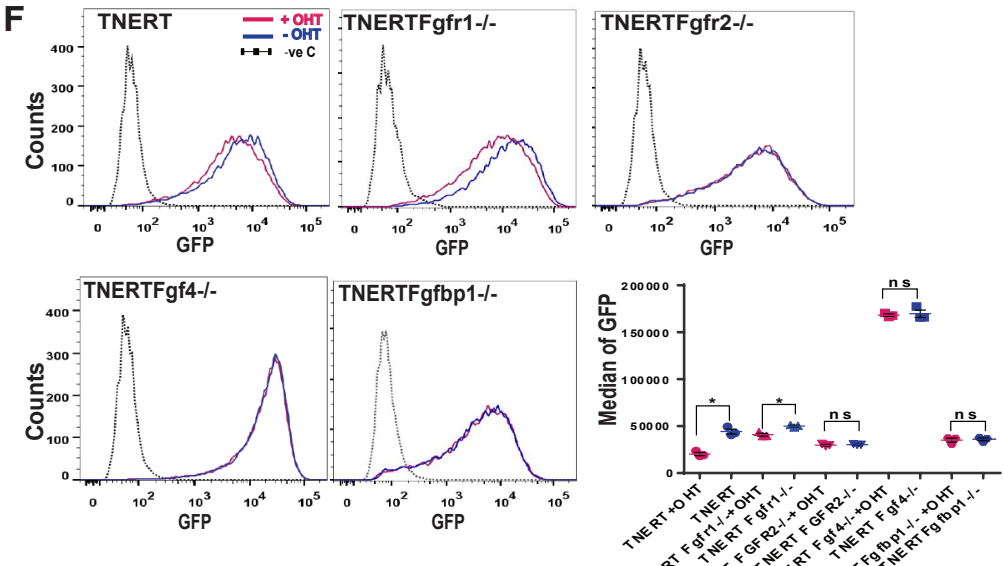
bioRxiv preprint doi: https://doi.org/10.1101/2021.06.28 450121; this version posted June 29 2021. The copyright holder for this preprint Figurebic 3 was not certified by peer review) is the author/funder, who has granted bioRxiv a license to display the preprint in perpetuity. It is

A

TNERT +OHT-Ohrs $=$ TNERT +OHT-1hrs

- TNERT+OHT-0.5hrs $\square$ TNERT +OHT-2hrs

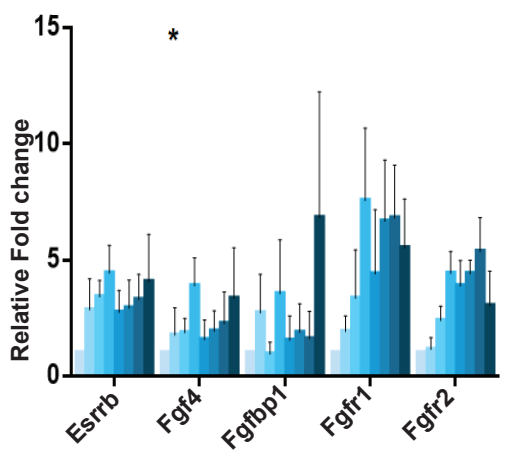

D

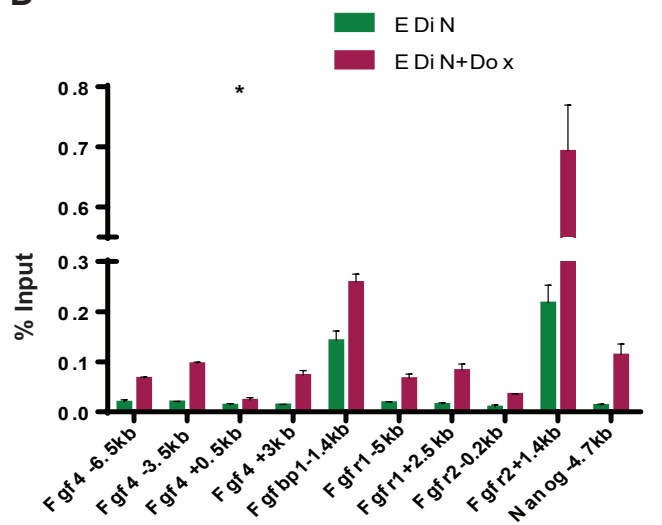

G

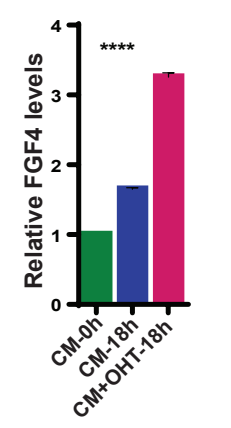

H

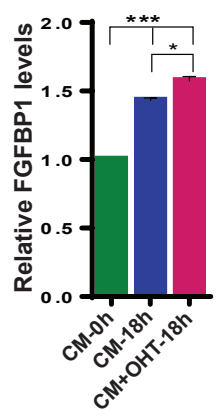

B

- TNERT +OHT-4hrs $=$ TNERT +OHT-12hrs

- TNERT+OHT-8hrs TNERT +OHT-18hrs

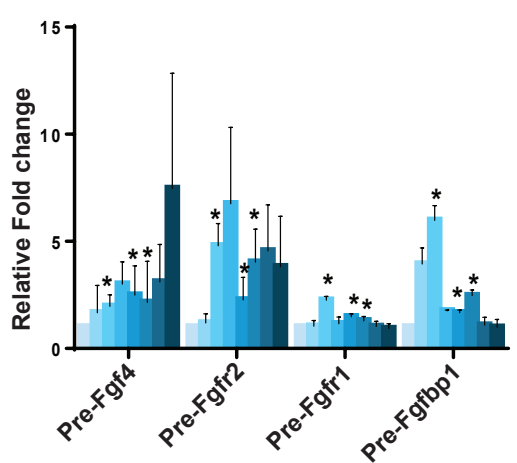

E

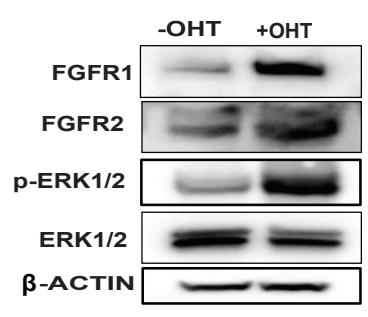

C

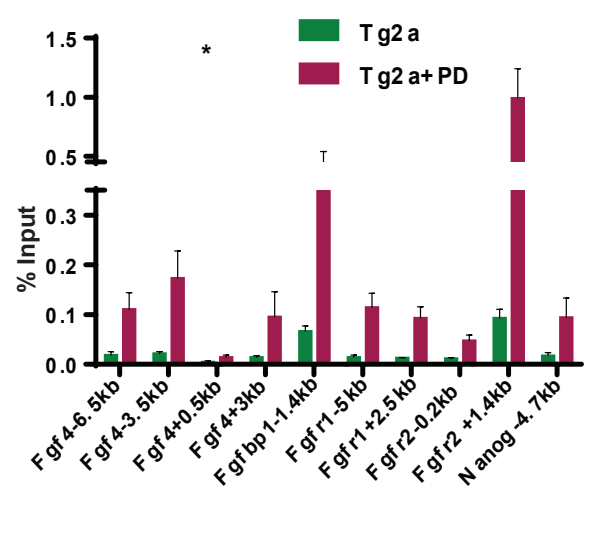

$\mathbf{F}$

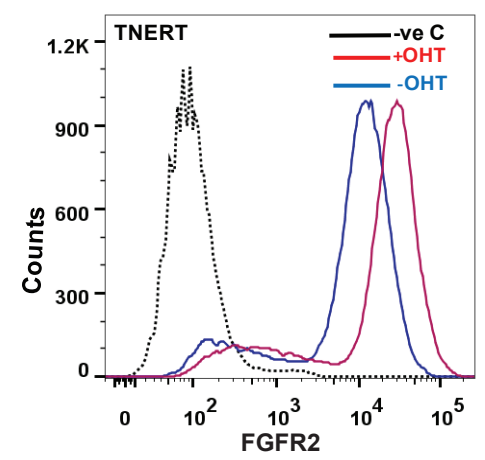

I

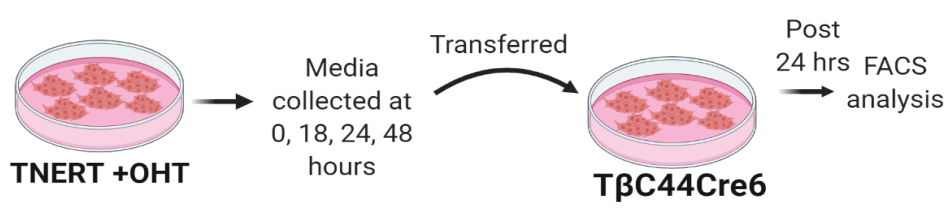

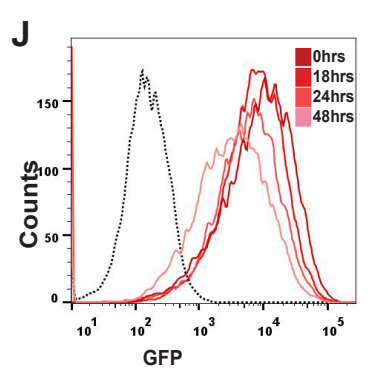
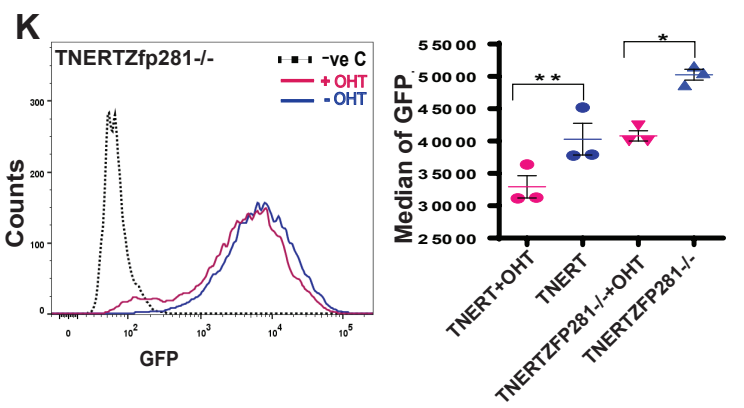

L

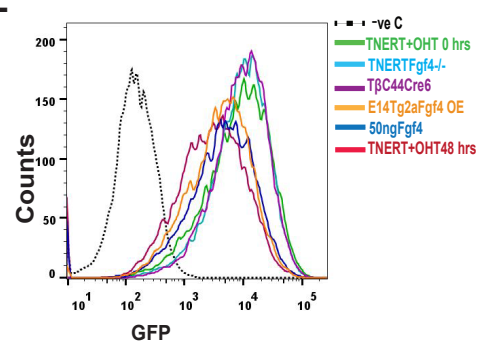


bioRxiv preprint doi: $\mathrm{https}$ ://doi.org/10.1101/2021.06.28.450121; this version posted June 29, 2021. The copyright holder for this preprint Figurewhi was not certified by peer review) is the author/funder, who has granted bioRxiv a license to display the preprint in perpetuity. It is made available under aCC-BY-NC-ND 4.0 International license.

A
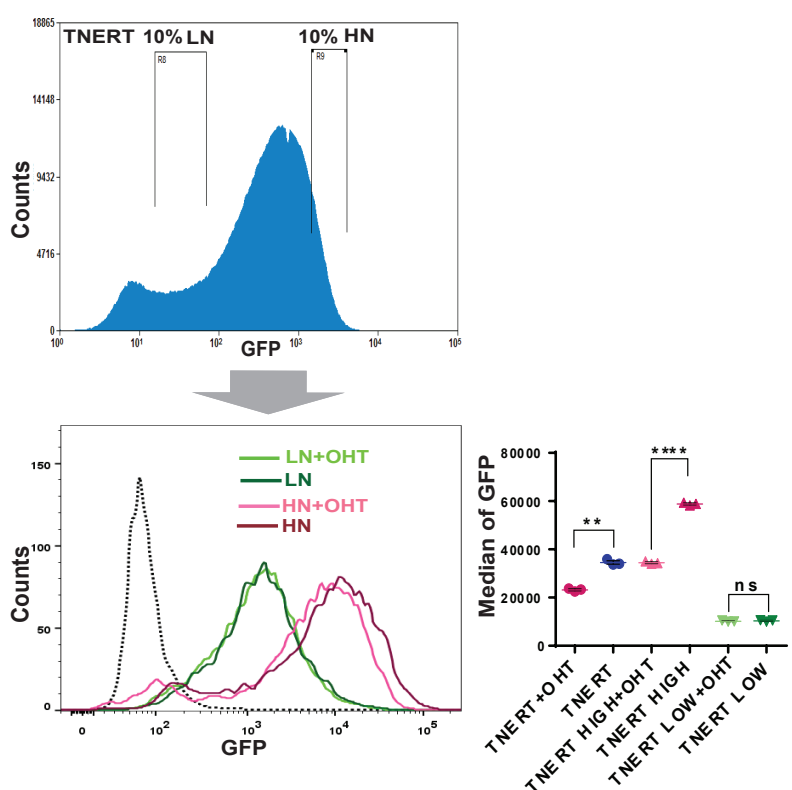

D

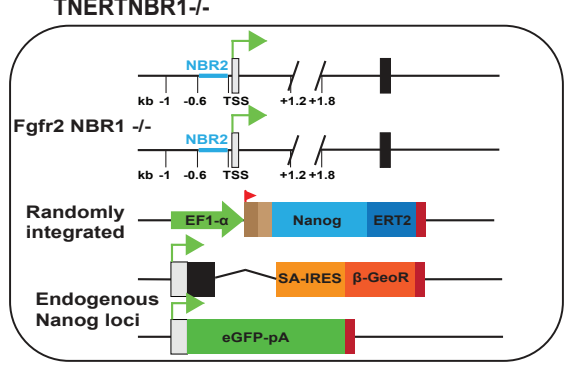

E TNERTNBR2-I-

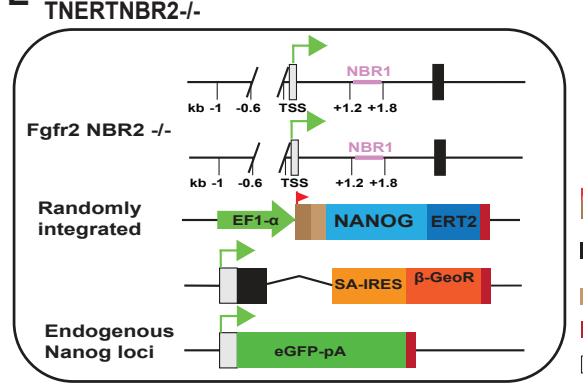

Flag tag

Exon (Coding)

Avidin tag

- Poly A

$\square$ Exon (Non-coding)

G

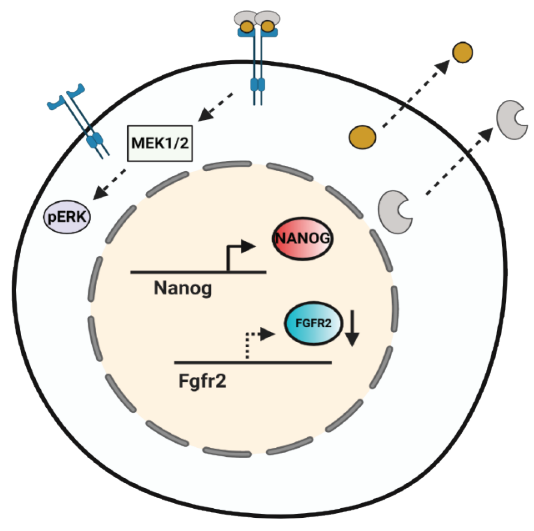

NANOG low cell
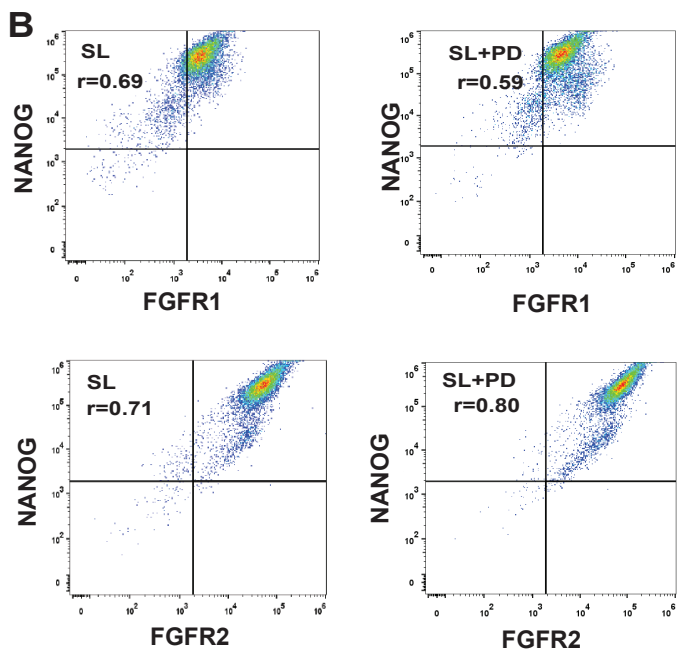

C
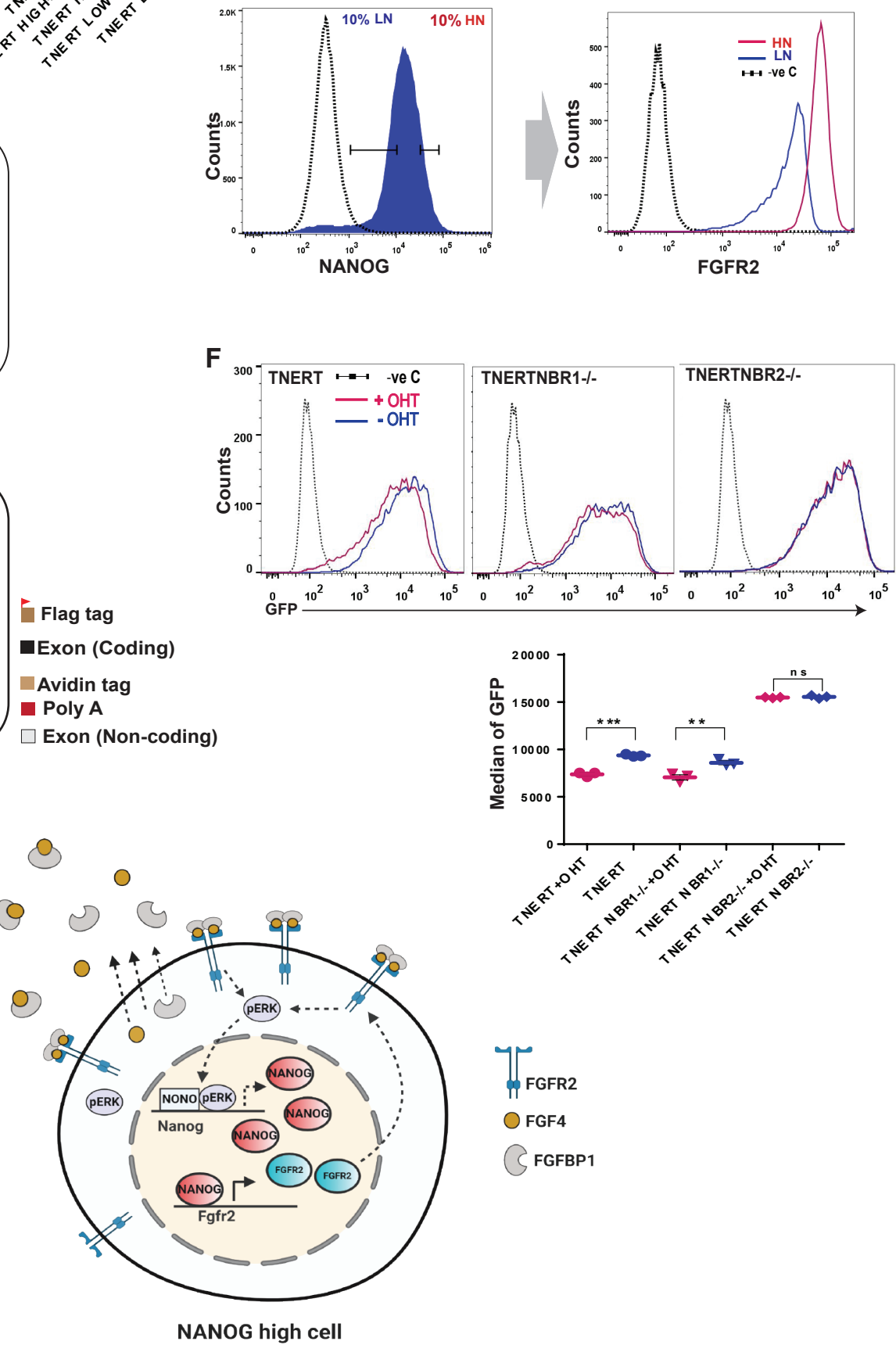

$\prod_{\text {FGFR2 }}$

O FGF4

CFGFBP1 
bioRxiy preprint doi: https:/doi.org/10.1101/2021.06.28.450121. this version posted June 29,2021 . The copyright holder for this preprint Figurention was not certified by peer review) is the author/funder, who has granted bioRxiv a license to display the preprint in perpetuity. It is made available under aCC-BY-NC-ND 4.0 International license.

a

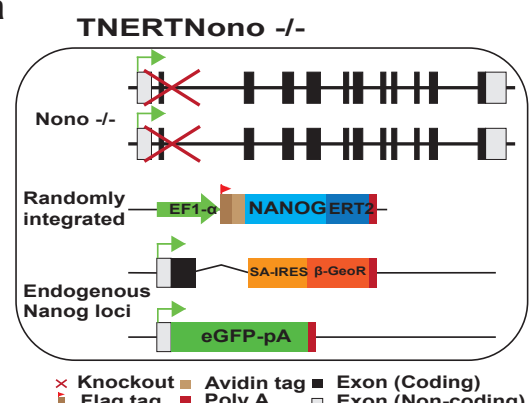

il Flag tag - Poly A Exon (Non-coding) b

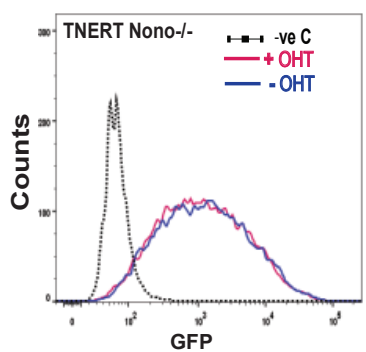

e

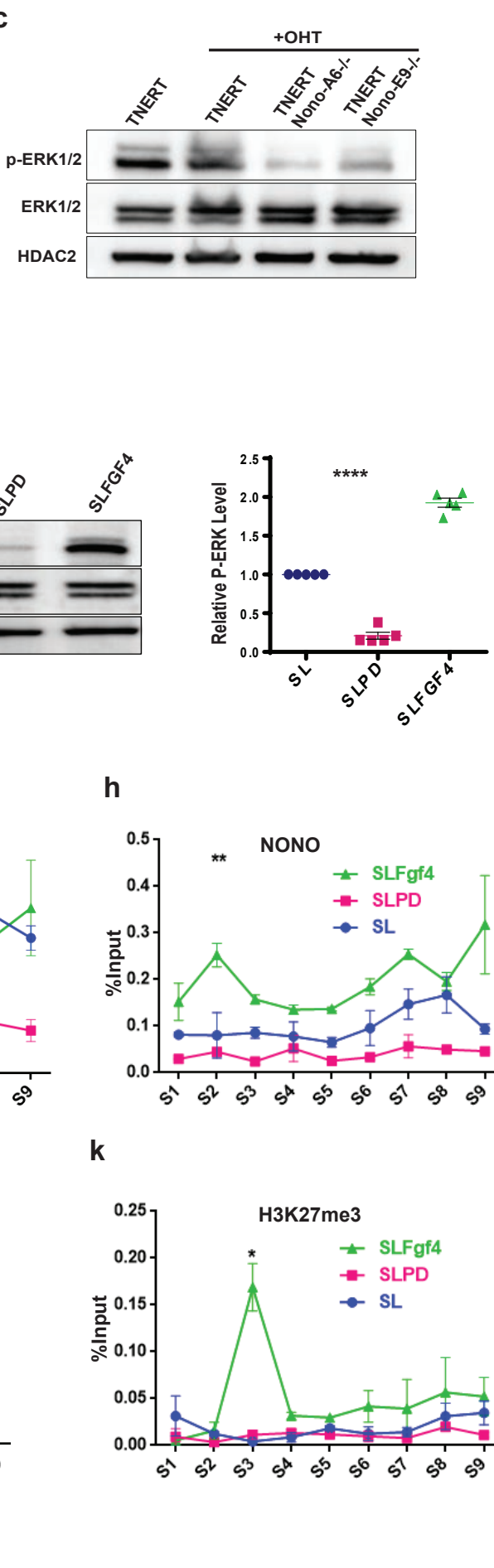

d

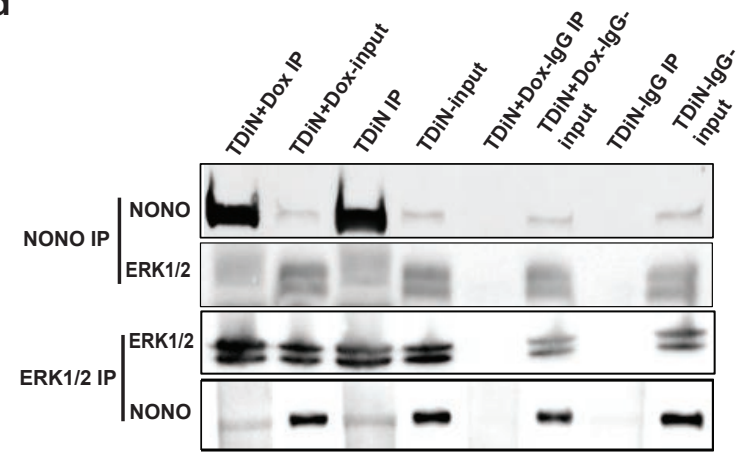

$\mathbf{f}$

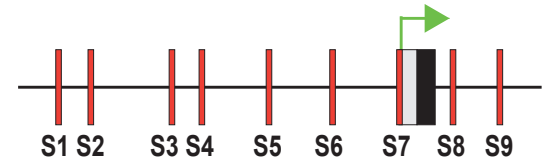

kb-5.5-4.9 $-3.9-3.4 \quad-1.9 \quad-1 \quad$ TSS $+.5+1.4$

g i

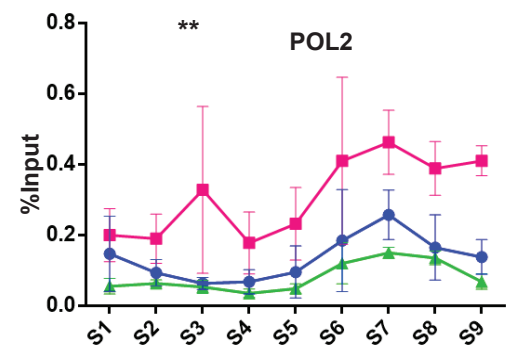

I

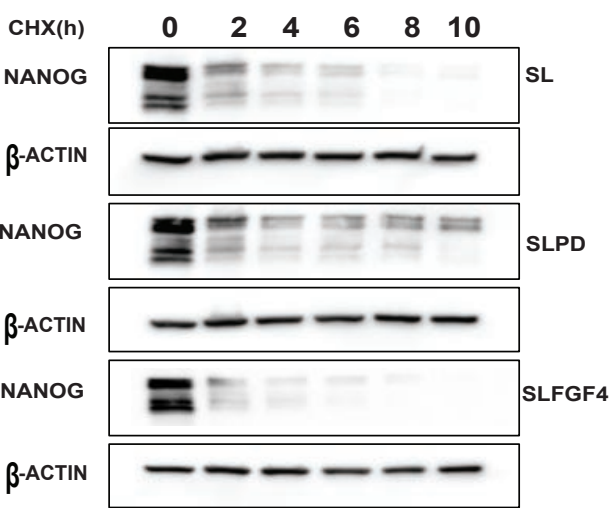

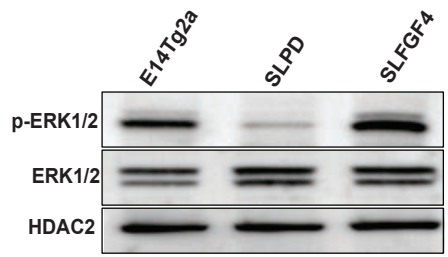

h

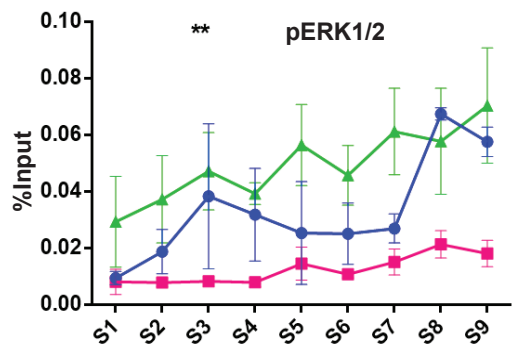

j

k

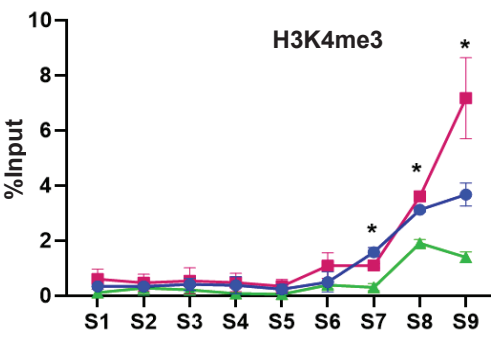

m

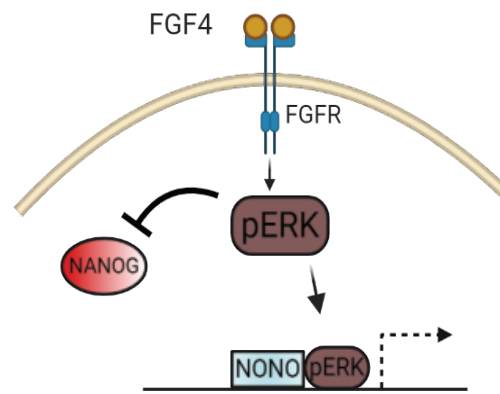

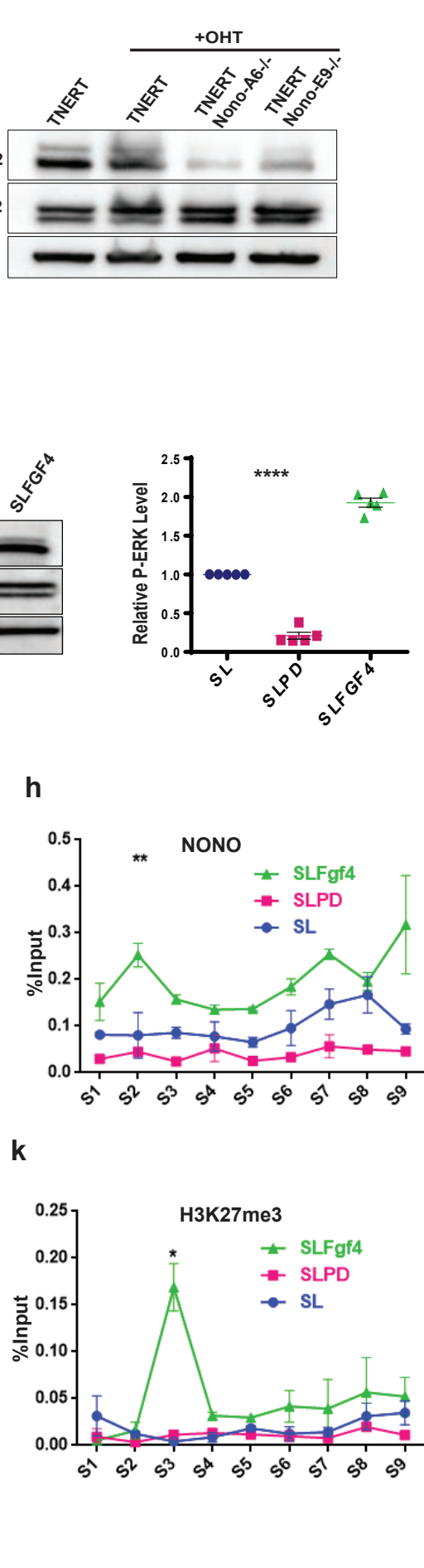
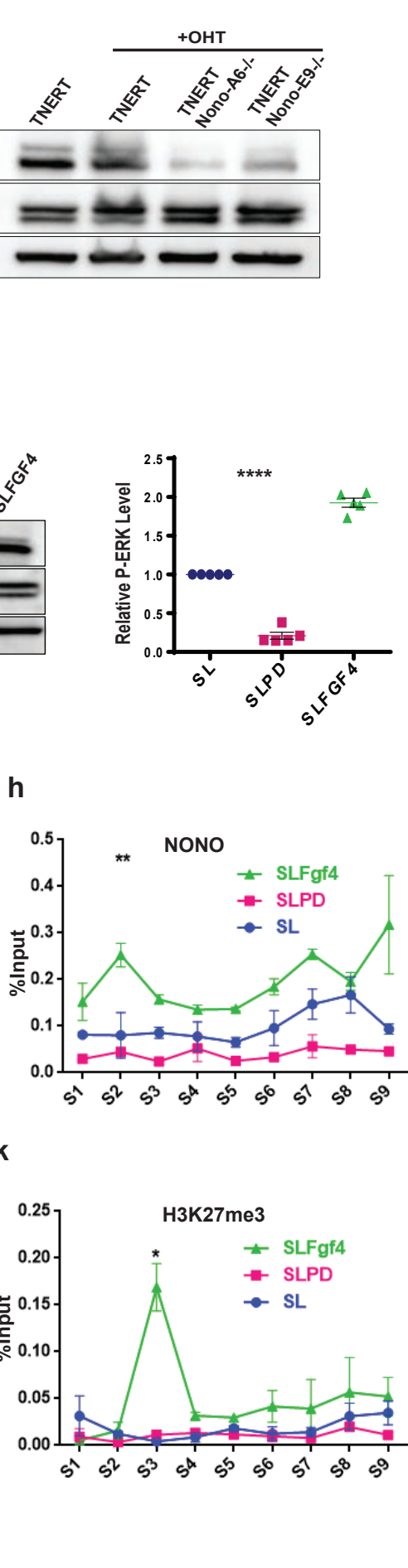
bioRxiv preprint doi: https:/doi.org/10.1101/2021.06.28.450121. this version posted June 29,2021 . The copyright holder for this preprint Figureto was not certified by peer review) is the author/funder, who has granted bioRxiv a license to display the preprint in perpetuity. It is made available under aCC-BY-NC-ND 4.0 International license.

A

C

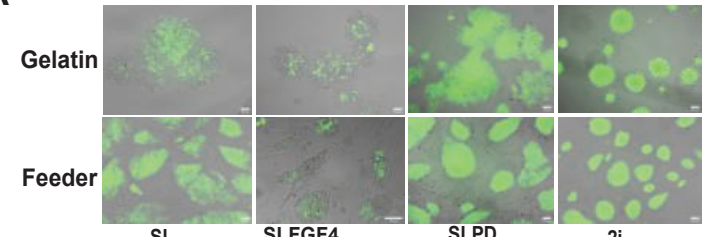

SL

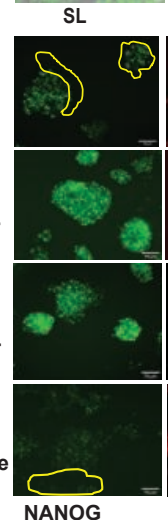

SLFGF4

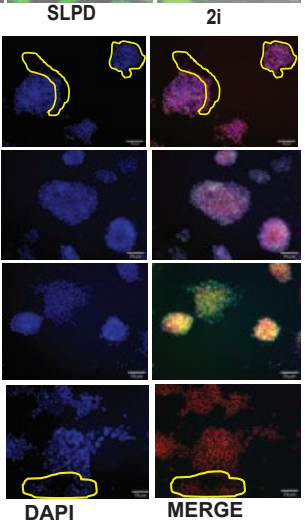

D

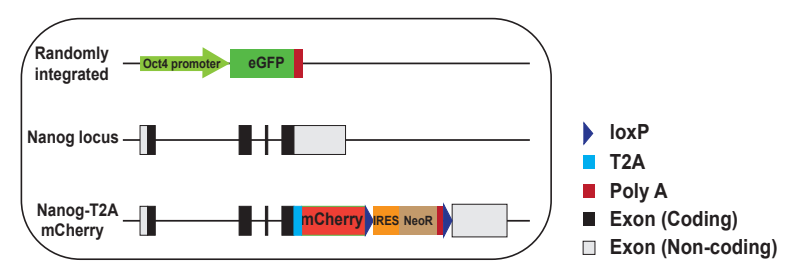

B

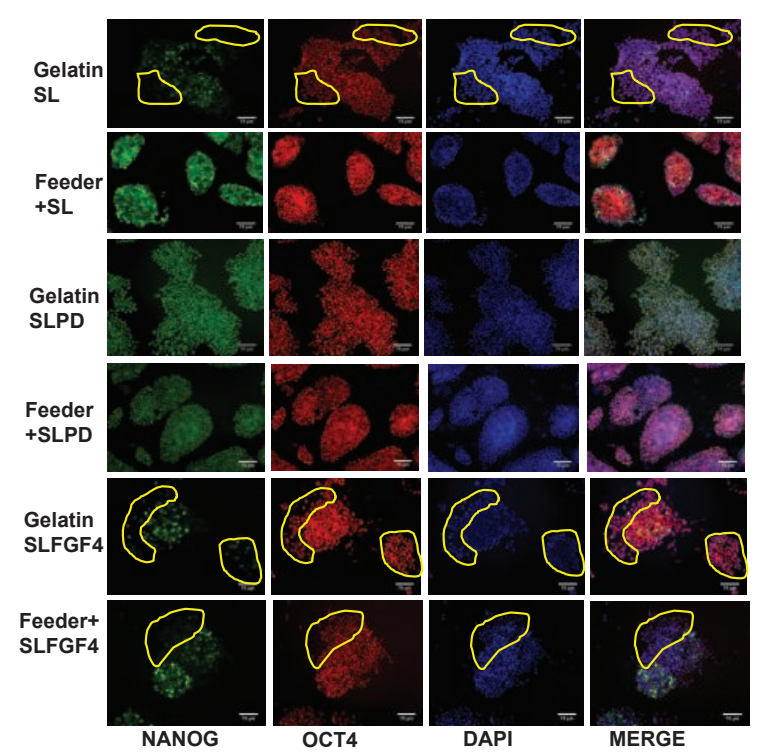

$E_{\text {Gel }}$

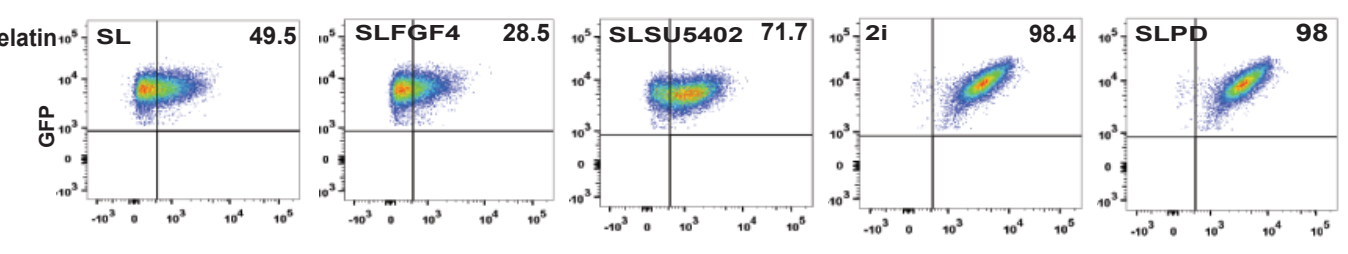

Feeder
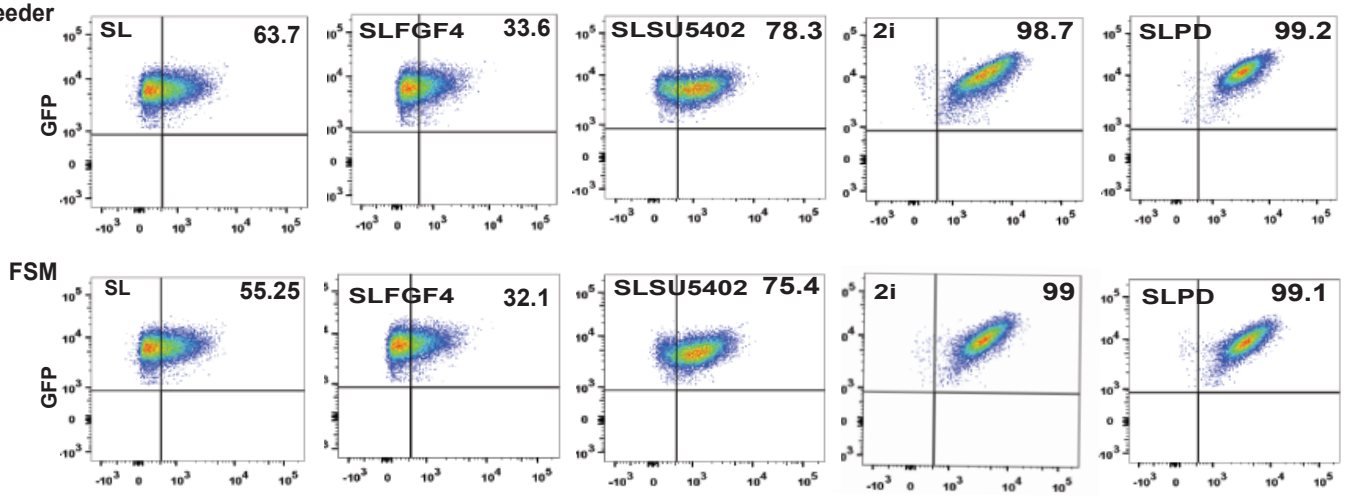

mCherry
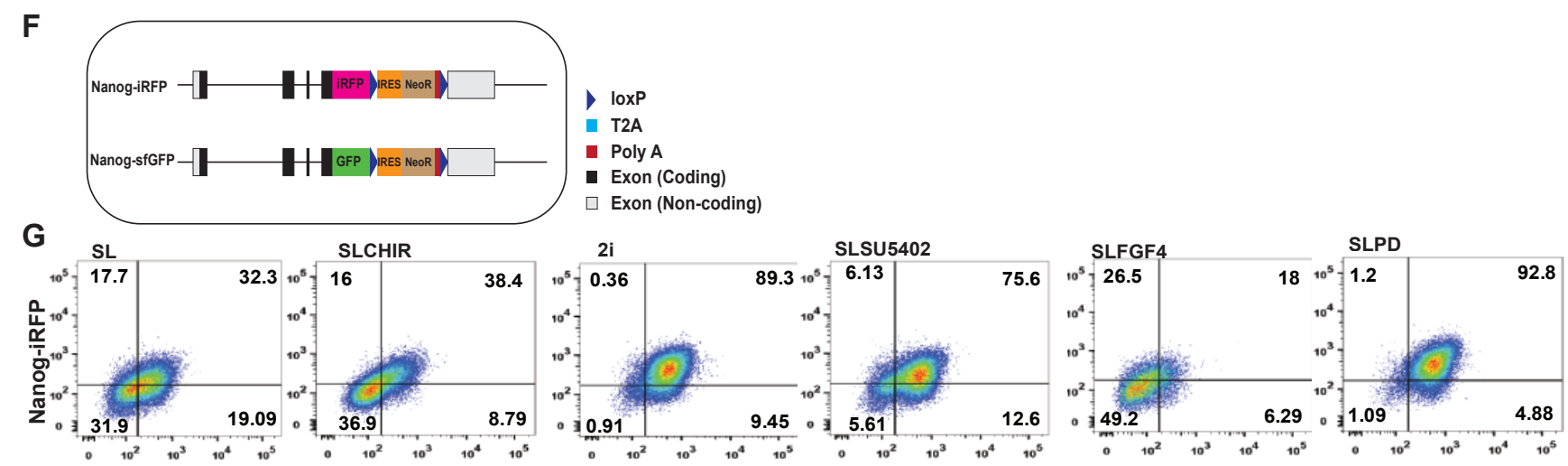

Nanog-sfGFP 
bioRxiv preprint doi: https://doi.org/10.1101/2021.06.28.450121; this version posted June 29,2021 . The copyright holder for this preprint (which was not certified by peer review) is the author/funder, who has granted bioRxiv a license to display the preprint in perpetuity. It is made available under aCC-BY-NC-ND 4.0 International license.

Figure 7

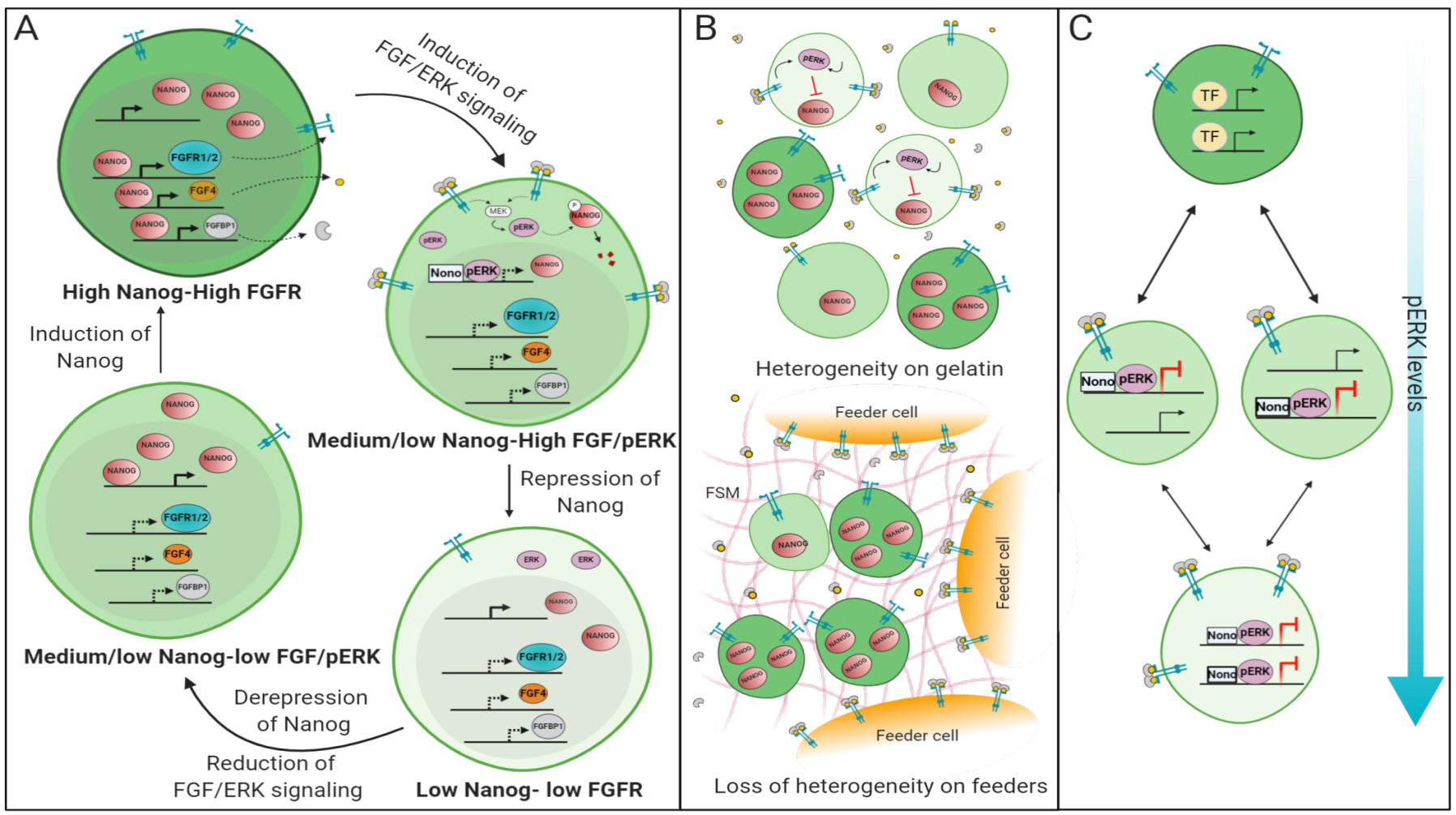


bioRxiv preprint doi: https://doi.org/10.1101/2021.06.28.450121; this version posted June 29, 2021. The copyright holder for this preprint (which was not certified by peer review) is the author/funder, who has granted bioRxiv a license to display the preprint in perpetuity. It is made available under aCC-BY-NC-ND 4.0 International license.

KEY RESOURCES

\begin{tabular}{|c|c|c|}
\hline REAGENT or RESOURCE & SOURCE & IDENTIFIER \\
\hline \multicolumn{3}{|l|}{ Antibodies } \\
\hline Anti-NANOG & Thermo Fisher Scientific & $\begin{array}{l}\text { Cat\# 14-5761-80, RRID: } \\
\text { AB } 763613\end{array}$ \\
\hline Anti-NANOG & Cell signaling Technology & $\begin{array}{l}\text { Cat\# 8822, RRID: } \\
\text { AB_11217637 }\end{array}$ \\
\hline Nanog Polyclonal Antibody & Thermo Fisher Scientific & $\begin{array}{l}\text { Cat\# PA5-47376, RRID: } \\
\text { AB_2607022 }\end{array}$ \\
\hline Anti-OCT3/4 & Cell signaling Technology & $\begin{array}{l}\text { Cat\# 83932, RRID: } \\
\text { AB } 2721046\end{array}$ \\
\hline Anti-OCT3/4 & Thermo Fisher Scientific & $\begin{array}{l}\text { Cat\# 14-5841-82, RRID: } \\
\text { AB_914301 }\end{array}$ \\
\hline Anti-SOX 2 & Cell signaling Technology & $\begin{array}{l}\text { Cat\# AMAb91307, RRID: } \\
\text { AB_2665892 }\end{array}$ \\
\hline Anti-FGFR2 & Thermo Fisher Scientific & $\begin{array}{l}\text { Cat\# PA1-24763, RRID: } \\
\text { AB_780623 }\end{array}$ \\
\hline Anti-FGFR2 & R\&D Systems & $\begin{array}{l}\text { Cat\# MAB6843, RRID: } \\
\text { AB_2103395 }\end{array}$ \\
\hline Anti-FGFR1 & Cell signaling Technology & $\begin{array}{l}\text { Cat\# 9740, RRID: } \\
\text { AB } 11178519\end{array}$ \\
\hline $\begin{array}{l}\text { FGFBP1 Polyclonal } \\
\text { Antibody }\end{array}$ & Thermo Fisher Scientific & $\begin{array}{l}\text { Cat\# PA5-77220, RRID: } \\
\text { AB_2720947 }\end{array}$ \\
\hline Anti-FGF4 & Thermo Fisher Scientific & $\begin{array}{l}\text { Cat\# PA5-20483, RRID: } \\
\text { AB_11152903 }\end{array}$ \\
\hline Anti-ERK1/2 & Cell signaling Technology & Cat\# 9102, RRID: AB_330744 \\
\hline Anti-P-ERK1/2 & Cell signaling Technology & Cat\# 4370, RRID: AB_2315112 \\
\hline Anti-P-ERK1/2 & Cell signaling Technology & Cat\#9101, RRID: AB_331646 \\
\hline $\begin{array}{l}\text { Anti-Trimethyl Histone } \\
\text { H3(Lys4) (C42D8) }\end{array}$ & Cell signaling Technology & Cat\# 9751, RRID: AB_2616028) \\
\hline $\begin{array}{l}\text { Anti-Trimethyl Histone } \\
\text { H3(Lys27) }\end{array}$ & Merck Millipore & Cat\# 07-449, RRID: AB_310624 \\
\hline Anti- $\beta$-ACTIN & Sigma-Aldrich & Cat\# A2228, RRID: AB_476697 \\
\hline Anti-HDAC2 & Thermo Fisher Scientific & $\begin{array}{l}\text { Cat\# 51-5100; RRID: } \\
\text { AB_2533908 }\end{array}$ \\
\hline $\begin{array}{l}\text { Anti-RNA polymerase II } \\
\text { Antibody, clone CTD4H8 }\end{array}$ & Merck Millipore & Cat\# 05-623, RRID: AB_309852 \\
\hline \multicolumn{3}{|c|}{ Chemicals, Peptides, and Recombinant Proteins } \\
\hline rhFGF4 & R\&D Systems & Cat\# 7460-F4-025 \\
\hline rhFGFBP1 & R\&D Systems & Cat\# 1593-FB-025 \\
\hline $\begin{array}{l}\text { Human FGF4 recombinant } \\
\text { protein }\end{array}$ & Thermo Fisher Scientific & Cat\# PHG0154 \\
\hline $\begin{array}{l}\text { Human BMP4 recombinant } \\
\text { protein }\end{array}$ & Thermo Fisher Scientific & Cat\# PHC9534 \\
\hline $\begin{array}{l}\text { Human EGF recombinant } \\
\text { protein }\end{array}$ & Thermo Fisher Scientific & Cat\# 01-107 \\
\hline $\begin{array}{l}\text { Human Insulin recombinant } \\
\text { protein }\end{array}$ & Thermo Fisher Scientific & Cat\# RP-10908 \\
\hline $\begin{array}{l}\text { Human bFGF recombinant } \\
\text { protein }\end{array}$ & Thermo Fisher Scientific & Cat\# RP-8628 \\
\hline G418 disulfate salt & Sigma-Aldrich & Cat\# A1720 \\
\hline Doxycycline Hyclate & Sigma-Aldrich & Cat\# D9891 \\
\hline
\end{tabular}




\begin{tabular}{|c|c|c|}
\hline SU5402 & Sigma-Aldrich & Cat\# SML0443 \\
\hline PD0325901 & Sigma-Aldrich & Cat\# PZ0162 \\
\hline CHIR99021 & Sigma-Aldrich & Cat\# SML1046 \\
\hline (Z)-4-Hydroxytamoxifen & Sigma-Aldrich & Cat\# H7904 \\
\hline LIF & Made in-house & \\
\hline Heparan sulfate sodium salt & Sigma-Aldrich & Cat\# H7640 \\
\hline $\begin{array}{l}\text { o-Phenylenediamine } \\
\text { dihydrochloride }\end{array}$ & Sigma-Aldrich & Cat\# P8287 \\
\hline \multicolumn{3}{|l|}{ Deposited Data } \\
\hline \multicolumn{3}{|c|}{ Experimental Models: Cell Lines } \\
\hline E14Tg2a & & Chambers et al., 2007 \\
\hline TNGA & & Chambers et al., 2007 \\
\hline TßC44Cre6 & & Chambers et al., 2007 \\
\hline TNERT & This Study & \\
\hline NiRFP2A & This Study & \\
\hline TDiN & This Study & \\
\hline OGNM & This Study & \\
\hline EDiN & This Study & \\
\hline NisGFPDiN & This Study & \\
\hline NsGiR & This Study & \\
\hline TNERTFgfr2-/- & This Study & \\
\hline TNERTFgfr1-/- & This Study & \\
\hline TNERTFgf4-/- & This Study & \\
\hline TNERTFgfbp1-/- & This Study & \\
\hline TNERTNBR1-/- & This Study & \\
\hline TNERTNBR2-/- & This Study & \\
\hline TNERTNono-/- & This Study & \\
\hline E14Tg2aFgf4-/- & This Study & \\
\hline E14Tg2aFgfr2-/- & This Study & \\
\hline E14Tg2aFgf4OE & This Study & \\
\hline \multicolumn{3}{|l|}{ Oligonucleotides } \\
\hline $\begin{array}{l}\text { Oligos used for sgRNA } \\
\text { cloning, genotyping, qPCR } \\
\text { - RTPCR and ChIP-PCR } \\
\end{array}$ & Supplemental Table 1 & \\
\hline \multicolumn{3}{|l|}{ Recombinant DNA } \\
\hline $\begin{array}{l}\text { pU6-(Bbsl)-CBh-Cas9-T2A- } \\
\text { mCherry }\end{array}$ & Addgene 64324 & (Weber et al., 2015) \\
\hline $\begin{array}{l}\text { Mouse Oct4-GFP GOF18 } \\
\text { transgenic reporter }\end{array}$ & Addgene 60527 & (Gafni et al., 2013) \\
\hline $\begin{array}{l}\text { Nanog iRFP670 Fusion } \\
\text { Targeting vector }\end{array}$ & This Study & \\
\hline $\begin{array}{l}\text { Nanog sfGFP Fusion } \\
\text { Targeting vector }\end{array}$ & This Study & \\
\hline Nanog-2A-mCherry & Addgene 59995 & (Faddah et al., 2013) \\
\hline pEF6V5His-Fgf4 & This Study & \\
\hline PEF6NanogERT2 & This Study & \\
\hline PTripZ-FaNanog & This Study & \\
\hline pU6-iRFP & This Study & \\
\hline pU6-iRFP Sg-Fgf4 & This Study & \\
\hline pU6-iRFP Sg-Fgfr1 & This Study & \\
\hline pU6-iRFP Sg-Fgfr2 & This Study & \\
\hline
\end{tabular}


bioRxiv preprint doi: https:/doi.org/10.1101/2021.06 28.450121. this version posted June 292021 . The copyright holder for this preprint (which was not certified by peer review) is the author/funder, who has granted bioRxiv a license to display the preprint in perpetuity. It is made available under aCC-BY-NC-ND 4.0 International license.

\begin{tabular}{|l|l|l|}
\hline pU6-iRFP Sg-Fgfbp1 & This Study & \\
\hline pU6-iRFP Sg-Zfp281 & This Study & \\
\hline pU6-iRFP Sg-Nono & This Study & \\
\hline pU6-iRFP Sg-Fgfr2-NBR1 & This Study & \\
\hline pU6-iRFP Sg-Fgfr2-NBR2 & This Study & \\
\hline pU6-iRFP Sg-Nanog-Stop & This Study & \\
\hline pMKiN & This Study & RRID: SCR_003070 \\
\hline Software and Algorithms & & RRID: SCR_008520 \\
\hline ImageJ & ImageJ & RRID: SCR_011793 \\
\hline FlowJo & BD Bioscience & RRID: SCR_015806 \\
\hline Integrative genomics viewer & Broad Institute & RRID: SCR_014210 \\
\hline SDS & Applied Biosystems & RRID: SCR_002798 \\
\hline Image Lab & Bio-rad & \\
\hline GraphPad Prism & GraphPad & Cat\# 88803 \\
\hline Other & & \\
\hline $\begin{array}{l}\text { Pierce Protein A/G } \\
\text { Magnetic beads }\end{array}$ & Thermo Fisher Scientific & N/A \\
\hline BD LSR Fortessa & BD Bioscience & N/A \\
\hline MoFLo XDP & Beckman Coulter & \\
\hline Gallios Flowcytometer & Beckman Coulter & N/A \\
\hline $\begin{array}{l}\text { Chemidoc MP imaging } \\
\text { system }\end{array}$ & Bio-rad & \\
\hline Zeiss Axio Observer & Zeiss & \\
\hline
\end{tabular}


bioRxiv preprint doi: https://doi.org/10.1101/2021.06.28.450121; this version posted June 29, 2021. The copyright holder for this preprint (which was not certified by peer review) is the author/funder, who has granted bioRxiv a license to display the preprint in perpetuity. It is made available under aCC-BY-NC-ND 4.0 International license.

A

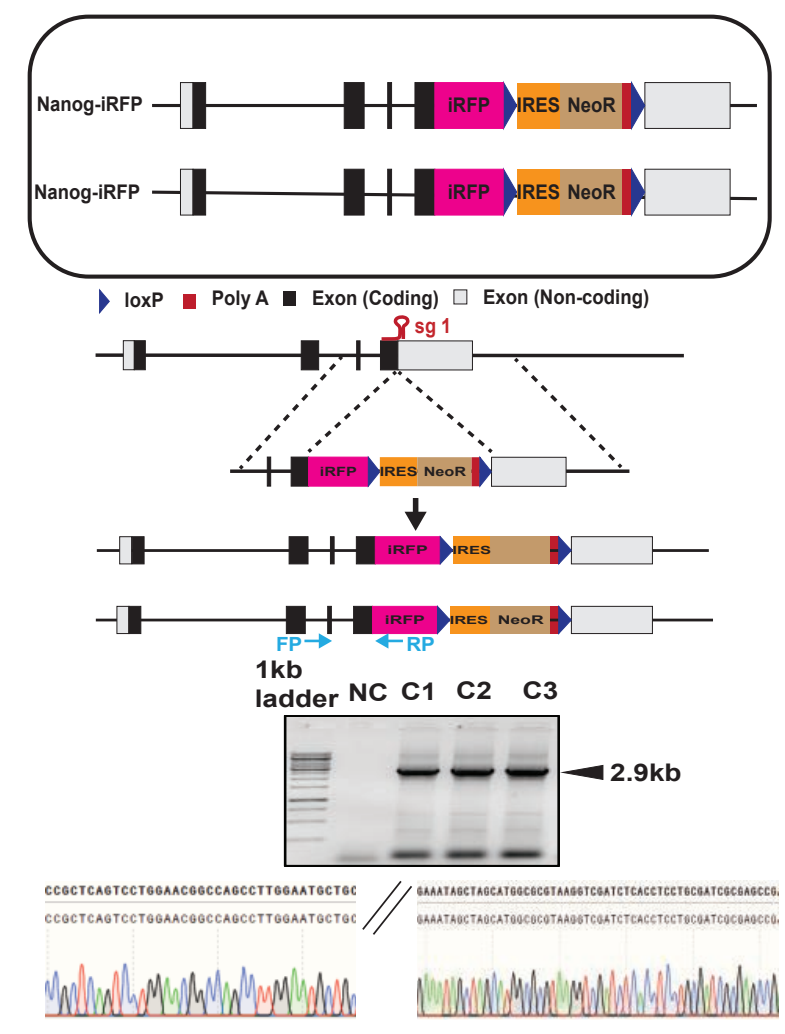

E
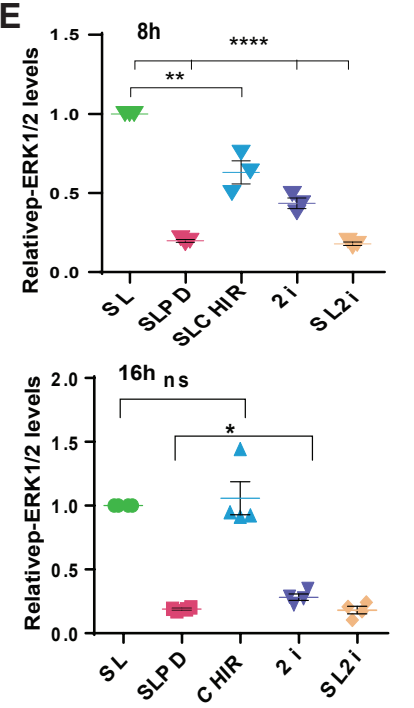

G
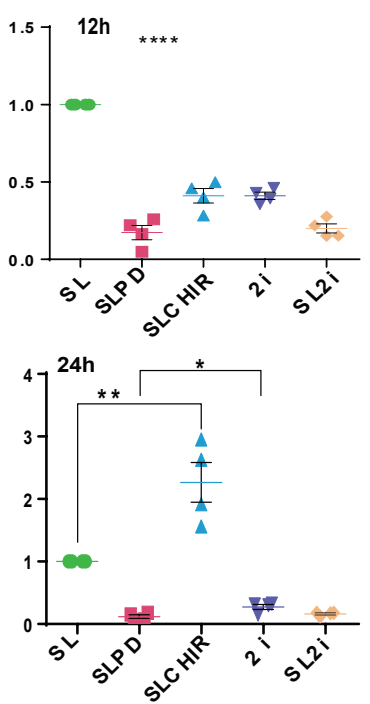

B

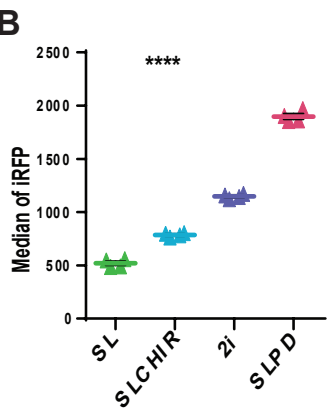

C

D
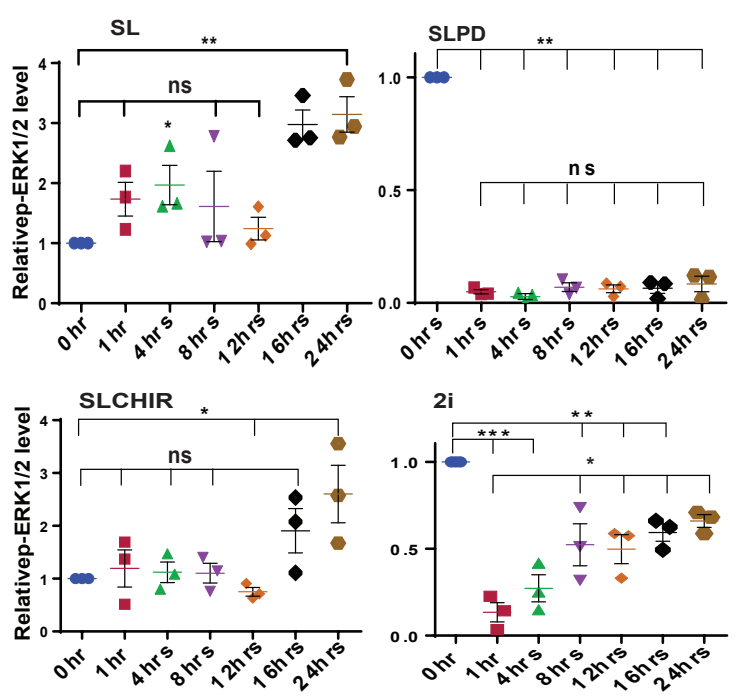

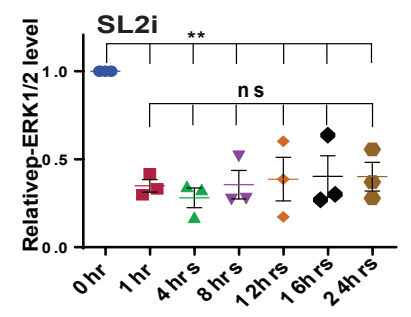

F

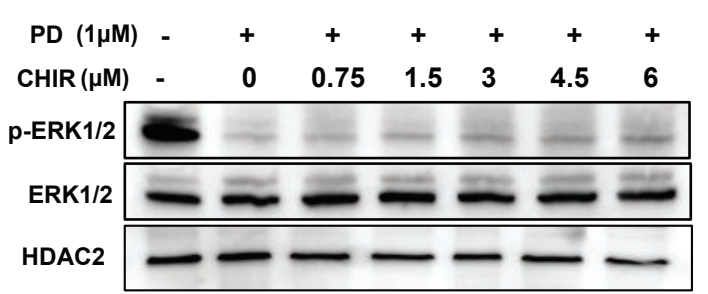

H
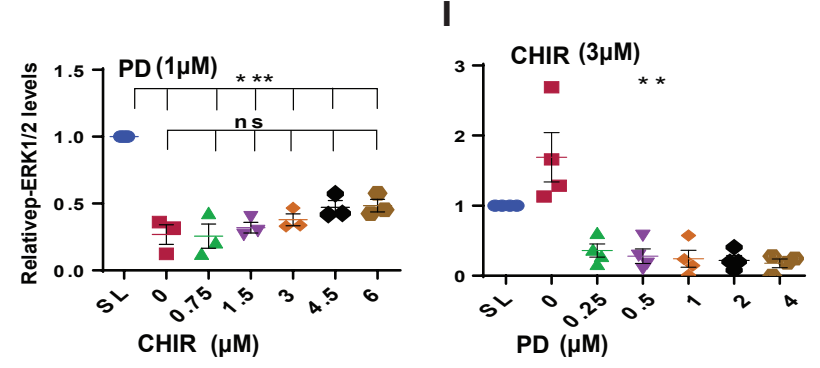
Supplemental data Fig 1: Residual MEK1/2 activity in the ground state prevents complete derepression of Nanog.

Related to Figure 1.

(A) (top) Schematic depiction of NiRFP2A with both alleles of Nanog fused to iRFP coding sequences in frame with last coding sequence. (middle) CRISPR mediated knock-in strategy of the iRFP-loxP-IRES-NeoR-loxP cassette into Nanog locus. The sgRNA includes the stop codon of the Nanog gene. The location of the genotyping primers (FP/RP) for the knock-in is marked by the arrows. (bottom) Genotyping of the NiRFP2A clones, a $2.9 \mathrm{~kb}$ band is amplified only in the knock-in clones as one of the primers is complementary to a sequence outside the left homology arm and the other primer is complementary to the iRFP sequence. (B) Relative quantification of the median of NANOG-iRFP population of NiRFP2A cells $(\mathrm{n}=4)$. (c) Relative quantification of OCT4 and SOX2. The expression is normalized relative to HDAC2 levels and expression levels of OCT4 and SOX2 in SL ( $\mathrm{n}>=3$ ). (D-E) Relative pERK1/2 expression levels in indicated time points and treatments $(n=3)$. (F) Western blot of pERK1/2 and ERK1/2 in $1 \mu \mathrm{M}$ PD and increasing concentrations of CHIR in SL media. (G) Western blot of pERK1/2 and ERK1/2 in $3 \mu \mathrm{M}$ CHIR and increasing concentrations of PD in SL media. (H-I) Relative pERK1/2 expression levels in indicated concentrations of CHIR and PD respectively ( $\mathrm{n}>=3)$. All error bars in the figure represent s.e.m. 
bioRxiv preprint doi: https://doi.org/10.1101/2021.06.28.450121; this version posted June 29, 2021. The copyright holder for this preprint (which was not certified by peer review) is the author/funder, who has granted bioRxiv a license to display the preprint in perpetuity. It is made available under aCC-BY-NC-ND 4.0 International license.

A

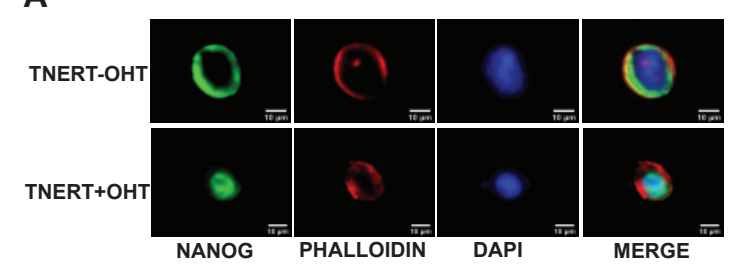

C

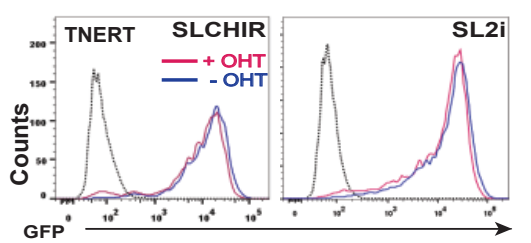

E

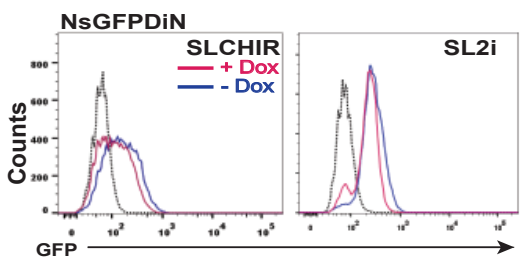

F $\quad$ TNERT+OHT $\quad$ T TDIN+DOX - NSGFPDiN+DOX

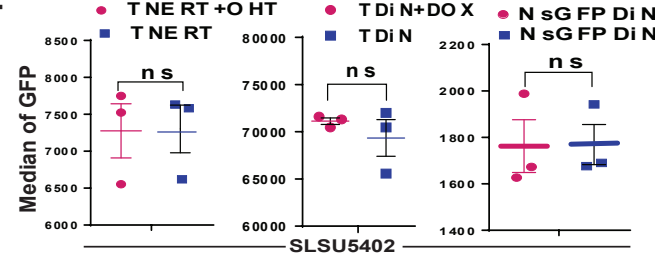

G

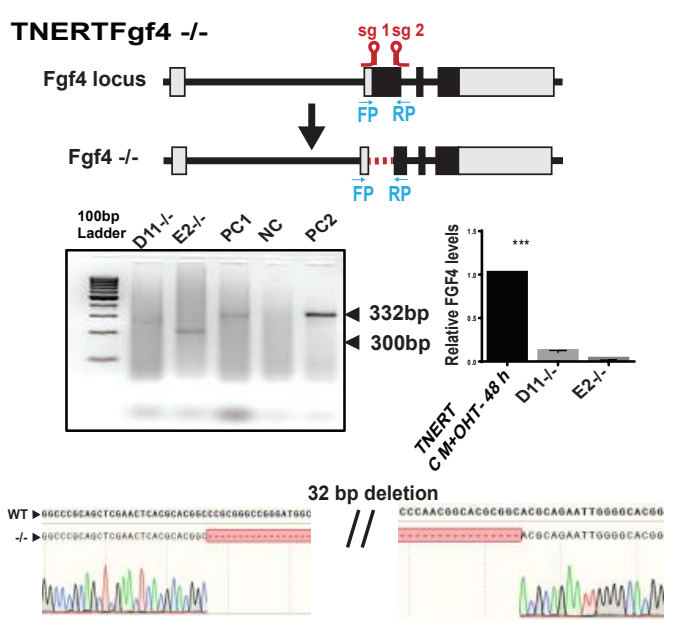

I TNERTFgfr1 - -
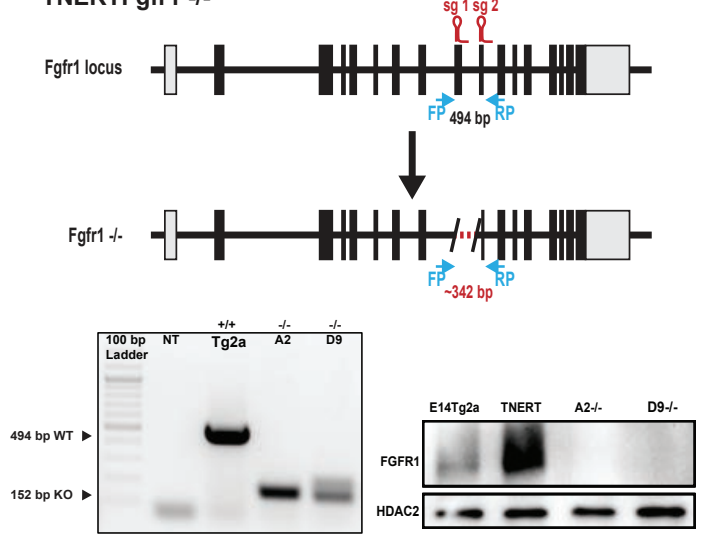

342 bp deletion

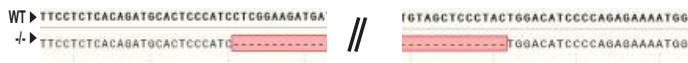

$B$
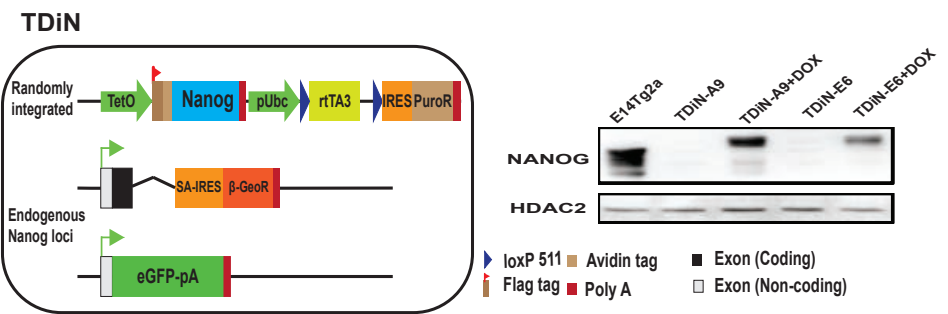

D TDiN
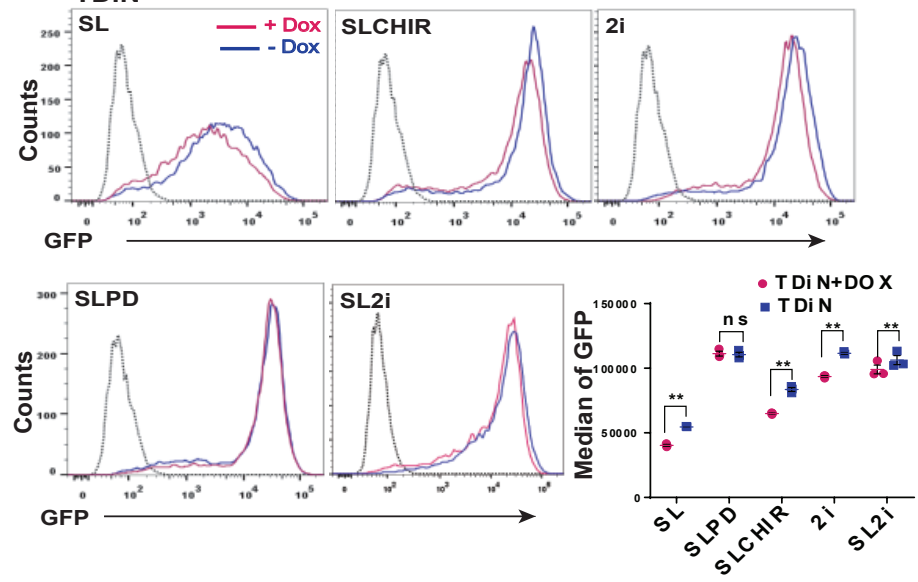

H TNERTFgfbp1 -1-
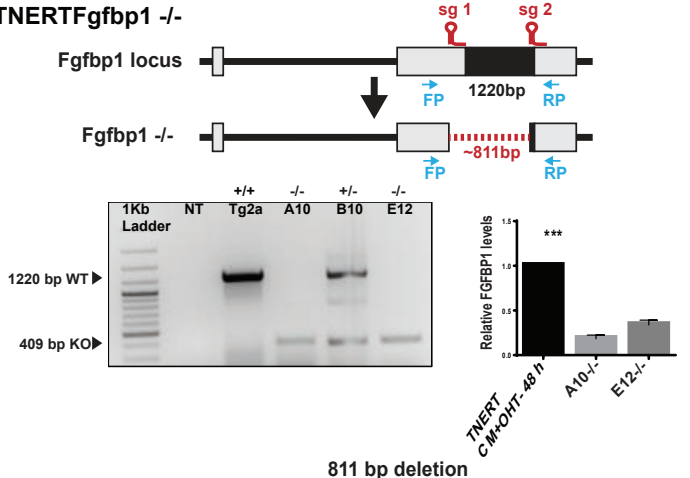

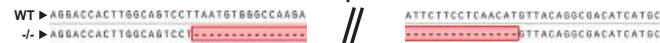

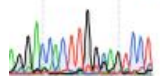

J TNERTFgfr2-I-
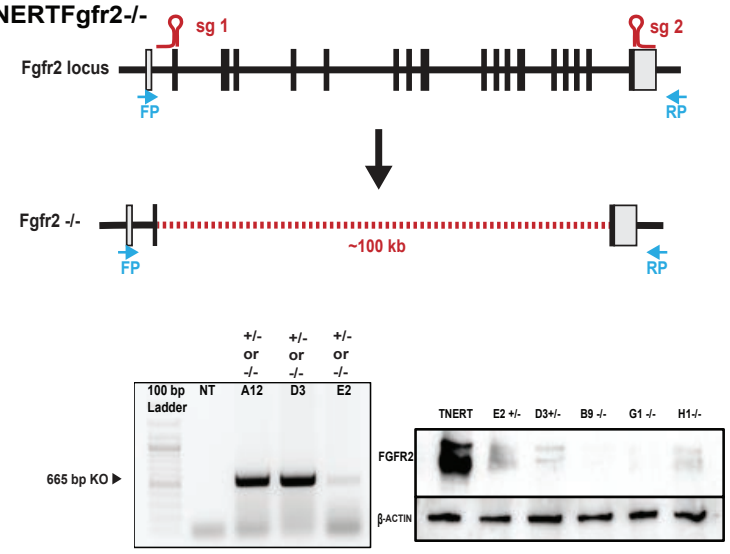

$100 \mathrm{~kb}$ deletion

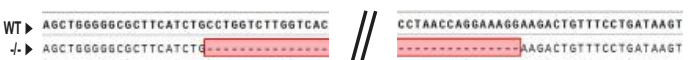


bioRxiv preprint doi: https://doi.org/10.1101/2021.06.28.450121; this version posted June 29, 2021. The copyright holder for this preprint (which was not certified by peer review) is the author/funder, who has granted bioRxiv a license to display the preprint in perpetuity. It is made available under aCC-BY-NC-ND 4.0 International license.

\section{Supplemental data Fig 2: FGF autocrine signaling pathway components are essential for Nanog autoregulation.}

Related to Figure 2.

(A) Immunofluorescence of NANOG in TNERT cells after 30 mins treatment with or no OHT. Scale bars represent $10 \mu \mathrm{M}$. (B) FACS profiles of TNERT treatment with or no OHT in SLCHIR and SL2i. (C) (left) Schematic of Doxycycline inducible TDiN cell line, generated by the introduction of a Tetracycline inducible Flag-Avi-NANOG (FaNANOG) transgene in T $\beta$ c44Cre6 cell line. (right) Western blot of FaNANOG in TDiN cells after 48 hrs treatment with or no Doxycycline. (D) FACS profiles of TDiN cell line in SL, SLCHIR, 2i, SL2i, and SLPD, (bottom right) Nanog:GFP population median of TDiN in indicated treatments $(\mathrm{n}=3)$. (E) FACS profiles of NsGFPDiN after 48 hrs of treatment with or no Doxycycline in SLCHIR and SL2i. (F) Nanog:GFP population median of TNERT, NsGFPDiN, and TDiN treated with SU5402, with OHT/Doxycycline or no OHT/Doxycycline. (G) (top) CRISPR-based knockout strategy using paired sgRNA to knock-out Fgf4 in TNERT. The sgRNAs are positioned at the beginning and the near end of exon II. The deletion results in the loss of the start codon and a part of the coding region in exon II. The dotted line represents the deleted region of the gene. FP and RP represent the relative positions of the genotyping primers. (middle left) genotyping PCR of TNERTFgf4-/- clones. The WT allele gives an amplicon of $332 \mathrm{bp}$ and the knock-out allele a smaller amplicon by 32 bps or more. (middle right) The relative abundance of FGF4 in media of TNERT and TNERTFgf4-/- clones 48 hrs after OHT treatment. (bottom) Chromatogram of the TNERTFgf4-/- clones showing the sequences at the junction of the deletion. (H) (top) Schematic of the gene structure of $F g f b p l$ and the relative positions of the two sgRNAs used for paired sgRNA knock-out strategy. One sgRNA is complimentary to 5'UTR and the other to the 3' end of the coding region of the only exon. (middle left) Genotyping PCR showing a WT amplicon of 1220 bps and an amplicon around $400 \mathrm{bps}$ in case of deletion. (middle right) The relative abundance of FGFFBP1 in media of TNERT and TNERTFgfbp1-/- clones 48 hrs after OHT treatment. (bottom) Chromatogram of the TNERTFgbp1-/- clone showing the sequences at the junction of the deletion. (I) Strategy for knock-out of Fgfrl in TNERT cells. The schematic depicts the gene structure of Fgfrl with the relative positions of the two sgRNAs. One sgRNA targets the 3 'end of Intron 8 and the other exon10. (middle left) Genotyping PCR shows a WT allele amplicon at $494 \mathrm{bp}$ and a knock-out allele with smaller amplicons around $150 \mathrm{bp}$. (middle right) Western blot analysis of FGFR1 in TNERT and TNERTFgfr1-/- clones. (bottom) chromatogram showing 
bioRxiv preprint do: https://doi.org/10.1101/2021.06.28.450121. this version posted June 29, 2021. The copyright holder for this preprint (which was not certified by peer review) is the author/funder, who has granted bioRxiv a license to display the preprint in perpetuity. It is made available under aCC-BY-NC-ND 4.0 International license.

the sequence of the deleted region (J) A paired sgRNA strategy to knock-out $F g f r 2$ in TNERT. (top) The schematic represents the Fgfr2 gene structure, with relative positions of the sgRNAs. One sgRNA target exon2 and the other sgRNA targets the coding region of the last exon approximately $100 \mathrm{~kb}$ apart. The dotted line represents the region of deletion in the $\mathrm{Fg} f \mathrm{r} 2$ gene. (middle left) PCR genotyping shows a $665 \mathrm{bp}$ amplicon when at least one allele of $F g f r 2$ is deleted. This genotyping strategy cannot distinguish between $+/$ - and -/- genotypes. (middle right) Western blot analysis of FGFR2 protein in the Fgfr2 targeted clones distinguishing the +/- and -/- clones. (bottom) chromatogram represents the sequence of the genotyping amplicon indicating the exact sites of deletion. All error bars in the figure represent s.e.m. 
bioRxiv preprint doi: https://doi.org/10.1101/2021.06.28.450121; this version posted June 29, 2021. The copyright holder for this preprint (which was not certified by peer review) is the author/funder, who has granted bioRxiv a license to display the preprint in perpetuity. It is made available under aCC-BY-NC-ND 4.0 International license.

A

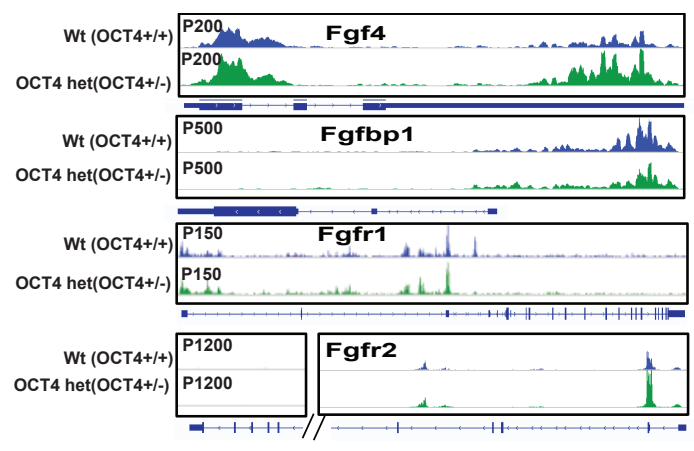

E

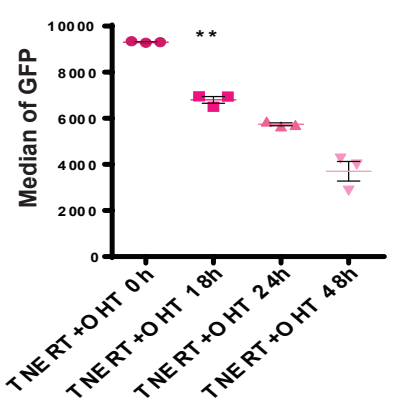

G

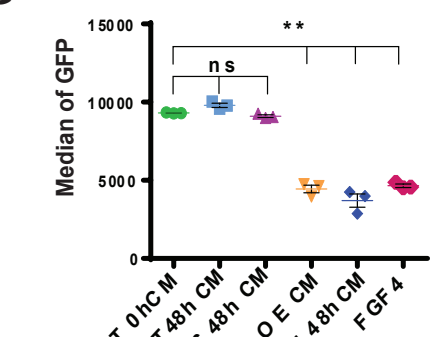

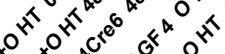

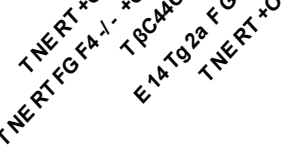

F
B

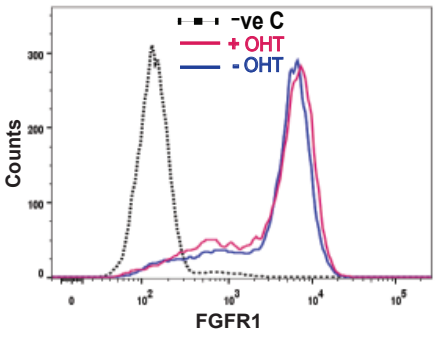

C

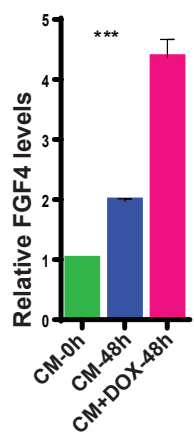

TNERTZfp281 \%-
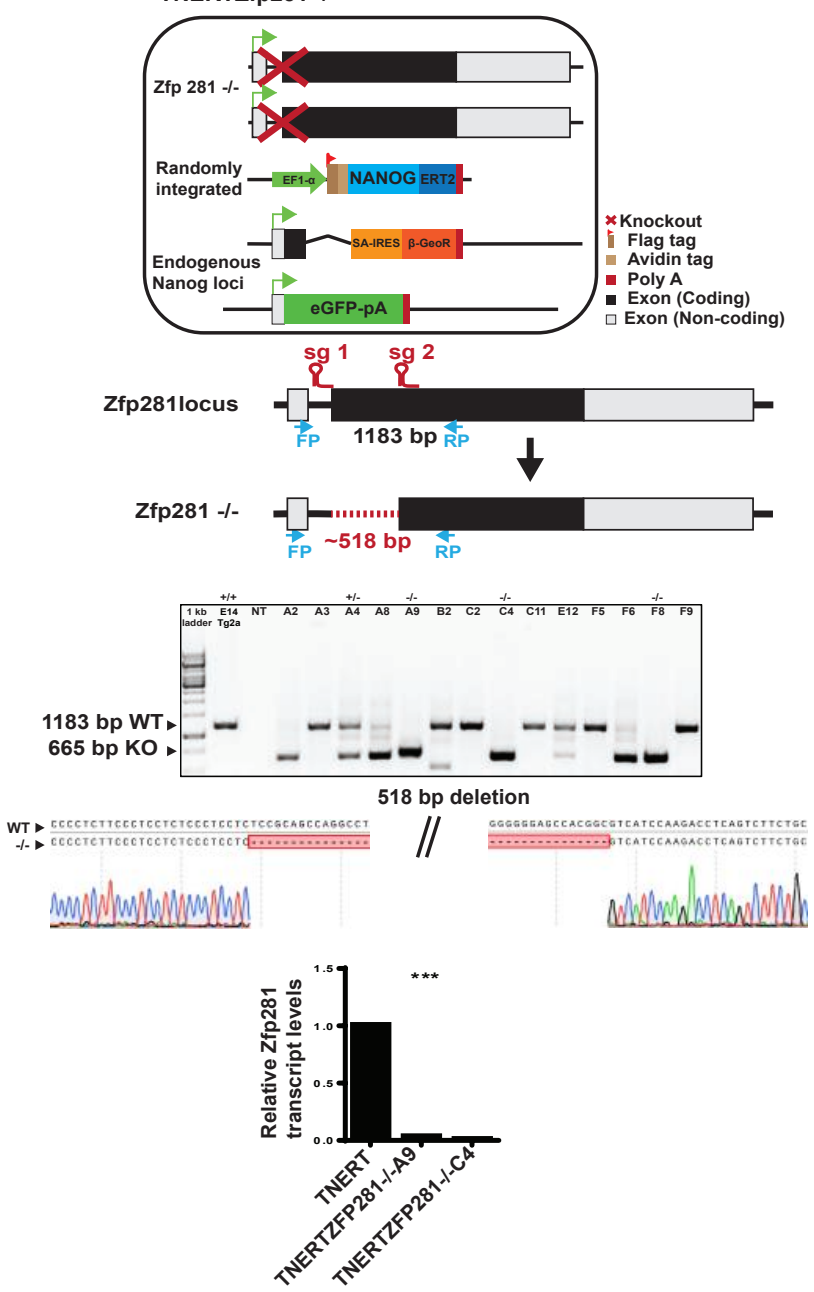

H

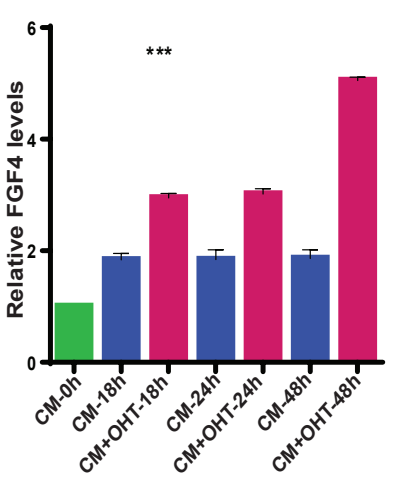

I

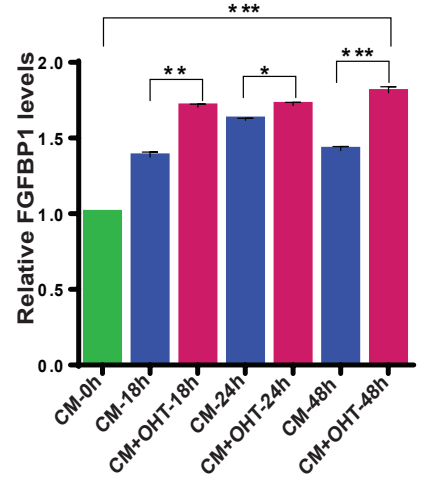

J

K
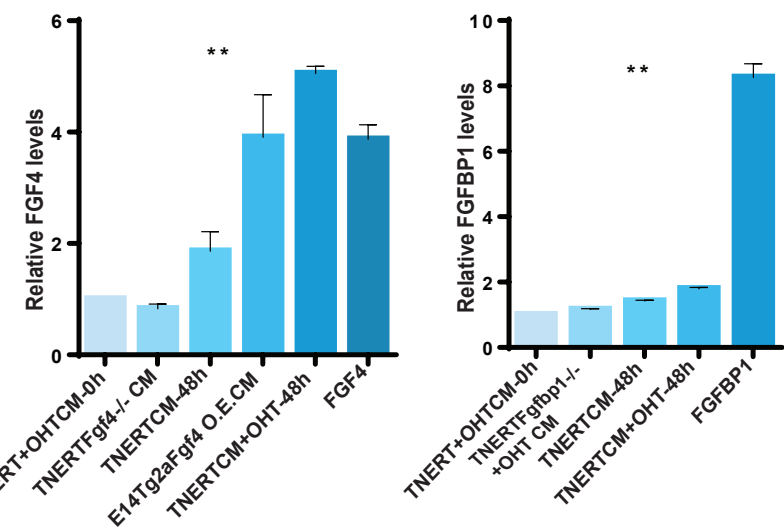
bioRxiv preprint doi: https://doi.org/10.1101/2021.06.28.450121: this version posted June 29, 2021. The copyright holder for this preprint (which was not certified by peer review) is the author/funder, who has granted bioRxiv a license to display the preprint in perpetuity. It is made available under aCC-BY-NC-ND 4.0 International license.

\section{Supplemental data Fig 3: Nanog enhances expression of FGF autocrine signaling pathway components.}

Related to Figure 3.

(A) Browser tracks of NANOG enrichment in Fragment Per Kilobase of transcripts per Million (FPKM) in Oct4+/+ cells (normal NANOG levels) and Oct4+/- cells (higher NANOG levels) (Karwacki-Neisius et al., 2013) at Fgf4, Fgfbpl, Fgfrl, and Fgfr2 loci. (B) Histogram of FGFR1 expression on the cell surface analyzed by immunostaining and FACS of fixed but unpermeabilized TNERT cells treated with (red) or no OHT (blue). (C-D) ELISA-based relative quantification of FGF4 and FGFBP1in media from EDiN cells cultured with or no Doxycycline $(n=3)$. EDiN cell was generated by introducing a Doxycycline inducible FlagAvi-NANOG transgene in E14Tg2a cells. (E) Nanog:GFP population median of T $\beta \mathrm{c} 44 \mathrm{Cre} 6$ treated with OHT induced conditioned media collected after different time points $(n=3)$. $(F)$ (top) Schematic of TNERTZfp281-/- cells, (upper-middle) CRISPR based paired guide knock-out strategy indicating the relative position of the sgRNAs, FP and RP indicate the genotyping primers. (lower middle) Genotyping PCR indicating +/- and -/- clones. (bottom) The sequencing chromatogram of the deleted region confirms the exact site of deletion, followed by RT-qPCR analysis of the Zfp281 transcripts. (G) Nanog:GFP population median of T $\beta \mathrm{c} 44 \mathrm{Cre} 6$ treated with conditioned media from TNERT+OHT $0 \mathrm{hrs}$, TNERTFGF4-/+OHT 48 hrs, Tßc44Cre6 48 hrs, E14Tg2a-FGF4-OE (overexpression) 48 hrs, TNERT+OHT $48 \mathrm{hrs}$ and 50ng/ml FGF4 (n=3). (H-I) ELISA-based relative quantities of FGF4 and FGFBP1 in media from TNERT after 18, 24, and 48 hrs of OHT treatment ( $\mathrm{n}=3)$. (J) ELISA-based relative quantities of FGF4 in conditioned media from cell lines -TNERT+ OHT 0 hrs, TNERTFGF4-/- + OHT 48 hrs, E14Tg2a-FGF4-OE 48 hrs (overexpression), TNERT-/+OHT $48 \mathrm{hrs}$, and 50ng/ml FGF4 (n=3). (K) ELISA-based relative quantities of FGFBP1 in conditioned media from various cell lines - TNERT+ OHT 0 hrs, TNERT-Fgfbp1/- $48 \mathrm{hrs}+$ OHT, TNERT $48 \mathrm{hrs}-/+$ OHT, and $50 \mathrm{ng} / \mathrm{ml} \mathrm{FGBP1} \mathrm{(n=3).} \mathrm{All} \mathrm{error} \mathrm{bars} \mathrm{in} \mathrm{the}$ figure represent s.e.m. 
bioRxiv preprint doi: https://doi.org/10.1101/2021.06.28.450121; this version posted June 29, 2021. The copyright holder for this preprint (which was not certified by peer review) is the author/funder, who has granted bioRxiv a license to display the preprint in perpetuity. It is made available under aCC-BY-NC-ND 4.0 International license.

A

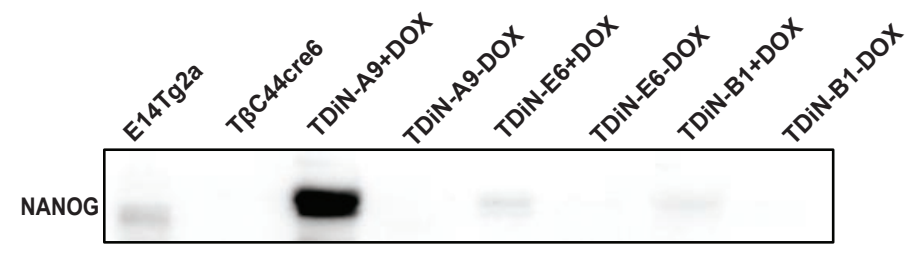

B
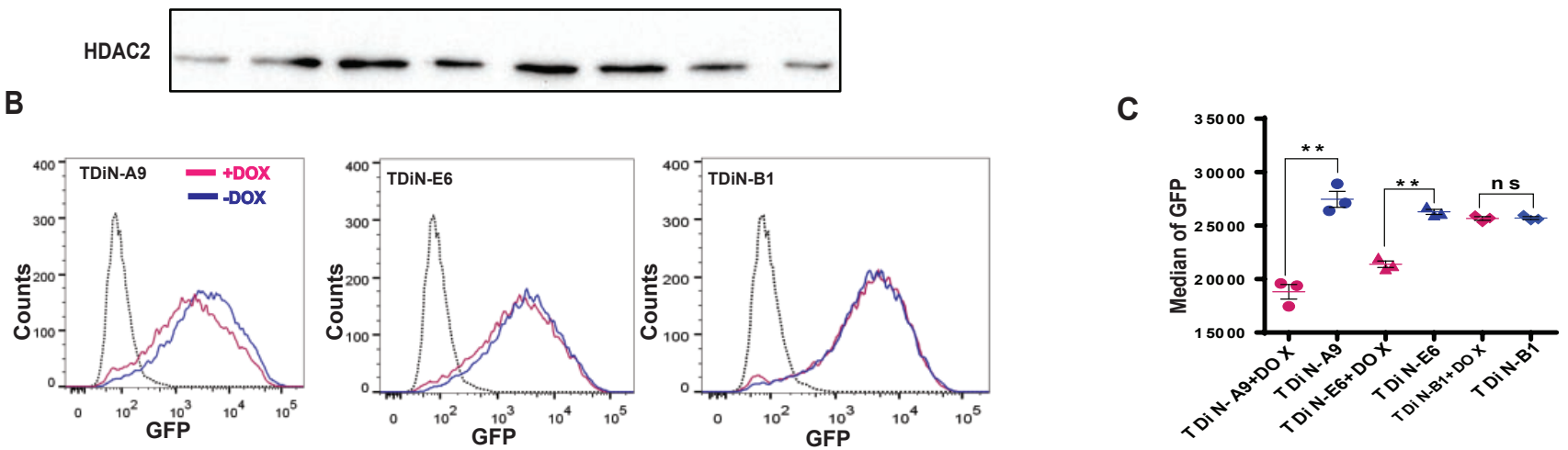

D

TNERTNBR1 -

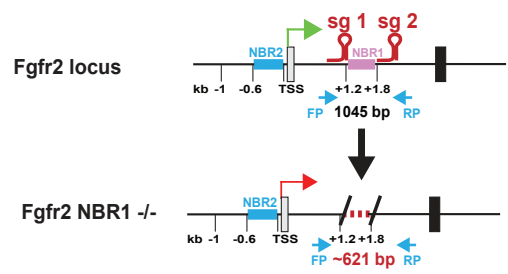

E

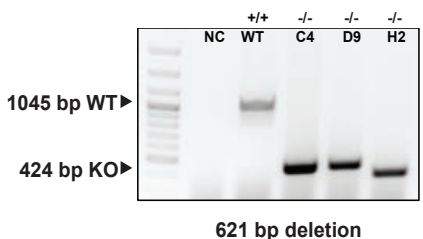

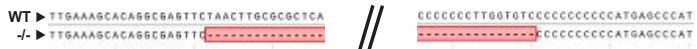
ancomomalunall

TNERTNBR2 - -
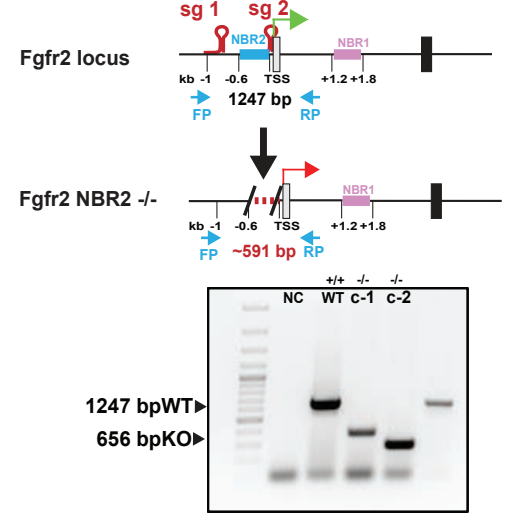

591 bp deletion

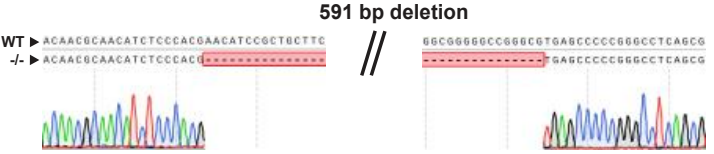


bioRxiv preprint doi: https://doi org/10.1101/2021.06.28.450121; this version posted June 29, 2021. The copyright holder for this preprint (which was not certified by peer review) is the author/funder, who has granted bioRxiv a license to display the preprint in perpetuity. It is made available under aCC-BY-NC-ND 4.0 International license.

\section{Supplemental data Fig 4: NANOG induced FGFR2 triggers autoregulation predominately in the ES cell population with higher Nanog expression.}

Related to Figure 4.

(A) Western blot analysis of Flag-Avi-NANOG in different clones of TDiN treated with or no Doxycycline showing different levels of NANOG expression relative to E14Tg2a. The clones show different levels of expression Flag- Avi-NANOG upon Doxycycline treatment. (B) FACS profiles of Nanog:GFP in TDiN clones treated with or no Doxycycline (C) Nanog:GFP population median of TDiN clones ( $n=3$ ). (D)(top) Schematic of strategy for deletion of NANOG Binding Region 1 (NBR1) in TNERT indicating the position of the NBR1 and the relative position of the sgRNA pair. The sgRNAs are complementary to sequences around 1.2 $\mathrm{kb}$ and $1.8 \mathrm{~kb}$ downstream of TSS. FP and RP indicate the relative position of the primers for genotyping. (middle) Genotyping of TNERT NBR1 knock-out clones. The WT shows an amplicon of $1045 \mathrm{bp}$, upon deletion around $600 \mathrm{bp}$ sequence comprising multiple NANOG binding sites is deleted. (bottom) Sequence and chromatogram of the genotype PCR amplicon indicating the exact sequence of the junction of deletion in TNERTNBR1-/- clone. (E) Schematic of strategy for deletion of NANOG Binding Region 2 (NBR2) in TNERT indicating the position of NBR2 and relative position of the sgRNA pair. The sgRNAs are complementary to sequences around TSS and $0.6 \mathrm{~kb}$ upstream of TSS of Fgfr2. (middle) Genotyping of the TNERTNBR2 knock-out clones. The WT shows an amplicon of $1247 \mathrm{bp}$. The knock-out would lead to deletion of around $690 \mathrm{bps}$ and a smaller amplicon of around $650 \mathrm{bps}$. (bottom) Sequence and chromatogram of the PCR amplicon from TNERT knock-out clones showing the exact site of deletion in TNERT NBR2-/- clone. All error bars in the figure represent s.e.m. 
bioRxiv preprint doi: https:/doi.org/10.1101/2021.06.28.450121. this version posted June 29,2021 . The copyright holder for this preprint (which was not certified by peer review) is the author/funder, who has granted bioRxiv a license to display the preprint in perpetuity. It is made available under aCC-BY-NC-ND 4.0 International license.

A

TNERTNono-/-

Nono locus

Nono $-\%$
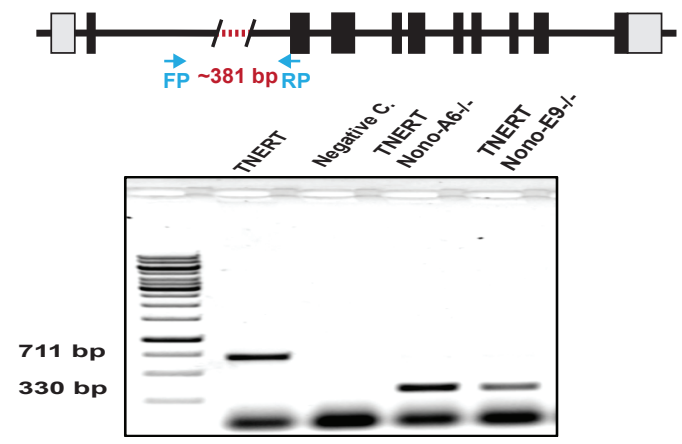

381 bp deletion

Wt c cggcccaagatagtittaatgatgggtaccatcagga // iagagagcgtcaagacaggetctctgtgtat

* cogcccaAgatagtttaatgatgggtacc-......
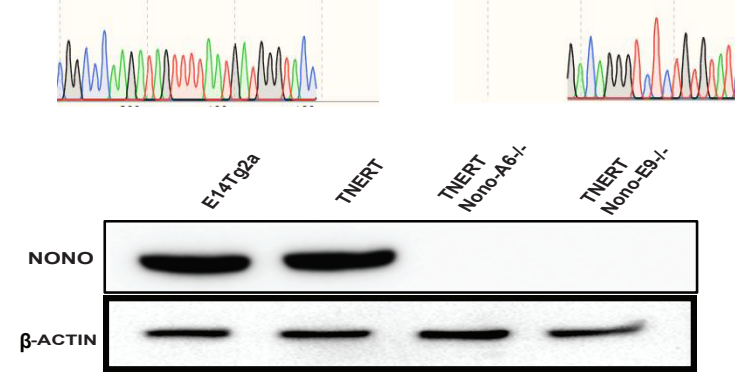

D

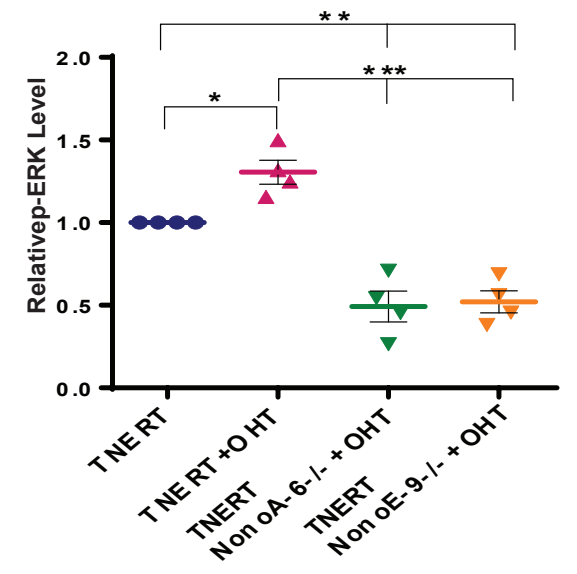

$\mathbf{F}$

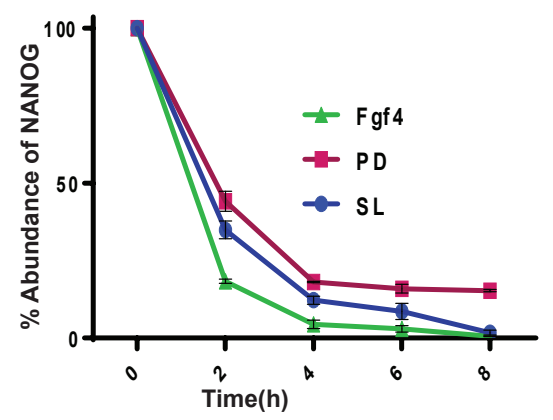

B
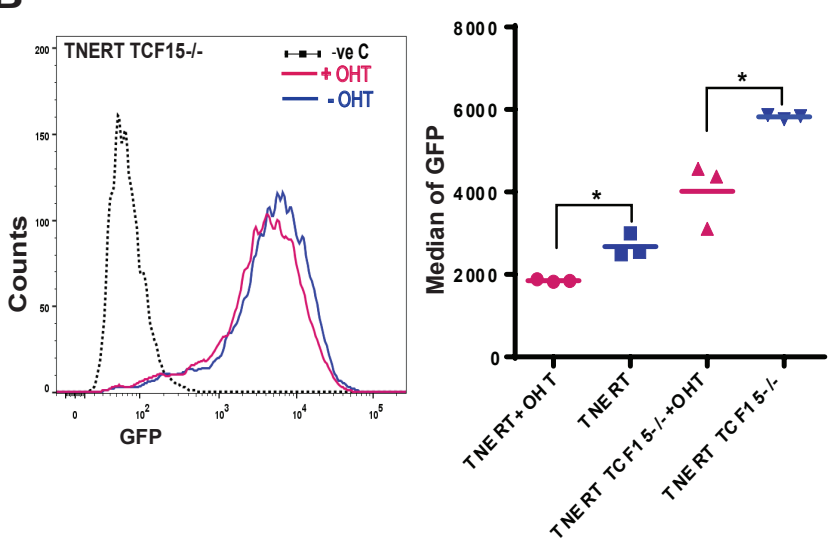

C

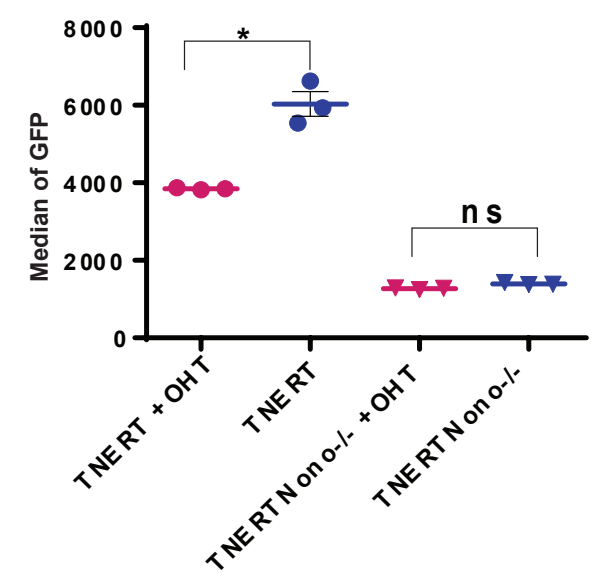

E
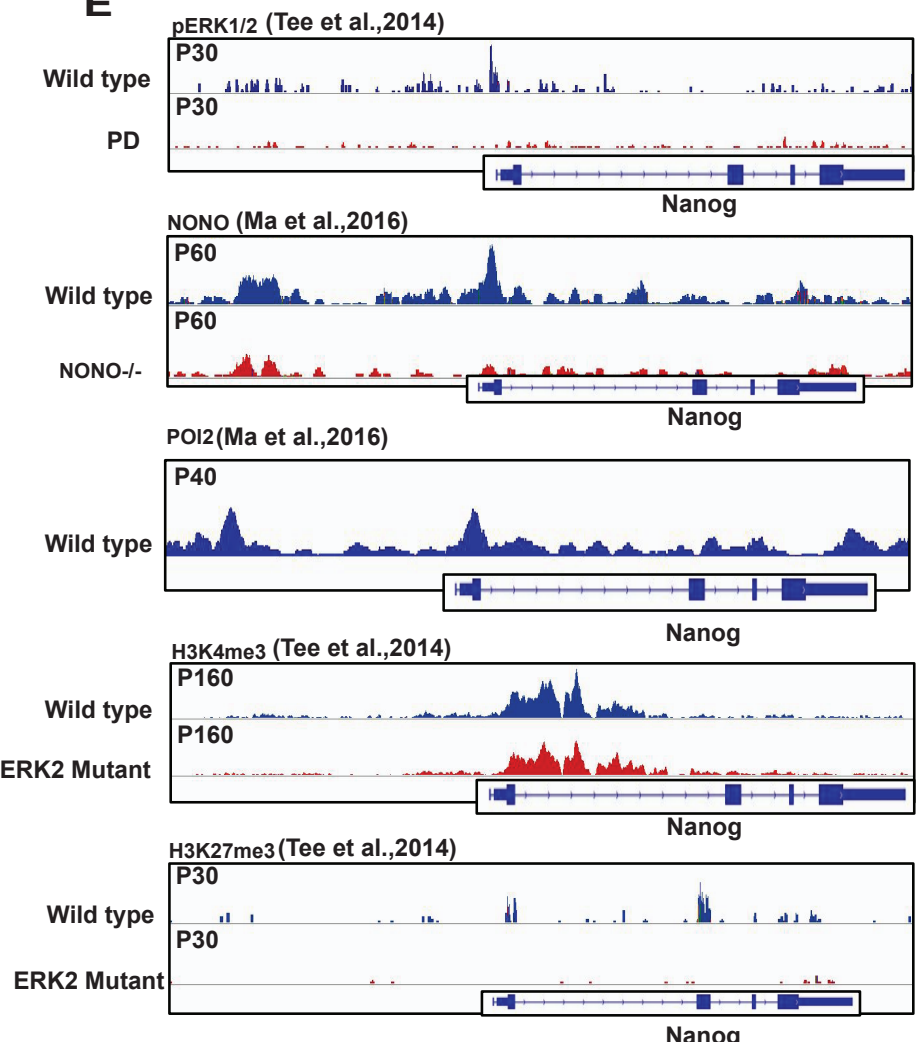


\section{Supplemental data Fig 5: ERK1/2 interacts and recruits NONO to repress Nanog transcription.}

Related to Figure 5.

(A) A CRISPR-based knock-out strategy using paired sgRNA, to knock-out of Nono in TNERT cells. (top) The schematic represents the mouse Nono gene structure with relative positions of the two sgRNAs flanking the second coding exon of Nono. FP and RP indicate the relative position of genotyping primers. The dotted line indicates the region of deletion in the Nono gene. (middle) Genotyping PCR of the Nono-/- deletion in TNERT. The WT allele gave an amplicon of $711 \mathrm{bp}$ and the deleted allele shows a smaller amplicon of $330 \mathrm{bp}$; followed by sequence and chromatogram indicating the deletion site (bottom) Western blot analysis of NONO protein in TNERT and TNERTNono-/- clones. (B) FACS profiles of TNERTTcf15-/cells, treated with OHT (red) or no OHT (blue). (Right) Nanog:GFP population median of TNERTTcf15-/- cells ( $\mathrm{n}=3)$. (C) Nanog:GFP population median of TNERT and TNERTNono-/- treated with or no OHT $(n=3)$. (D) The relative abundance of $p E R K 1 / 2$ in TNERT treated with or no OHT and TNERTNono-/- with OHT (n=4). (E) Browser tracks of pERK1/2, NONO, POL2, H3K4me3, H3K27me3 enrichment in Fragment Per Kilobase of transcripts per Million (FPKM) on Nanog gene (Ma et al., 2016; Tee et al., 2014) (F) The relative abundance of NANOG after $0,2,4,6$, and $8 \mathrm{hrs}$ of Cycloheximide (CHX) chase cultured in SL, PD, and FGF4 ( $\mathrm{n}=3$ ). All error bars in the figure represent s.e.m. 
bioRxiv preprint doi: https://doi.org/10.1101/2021.06.28.450121; this version posted June 29, 2021. The copyright holder for this preprint (which was not certified by peer review) is the author/funder, who has granted bioRxiv a license to display the preprint in perpetuity. It is made available under aCC-BY-NC-ND 4.0 International license.

A
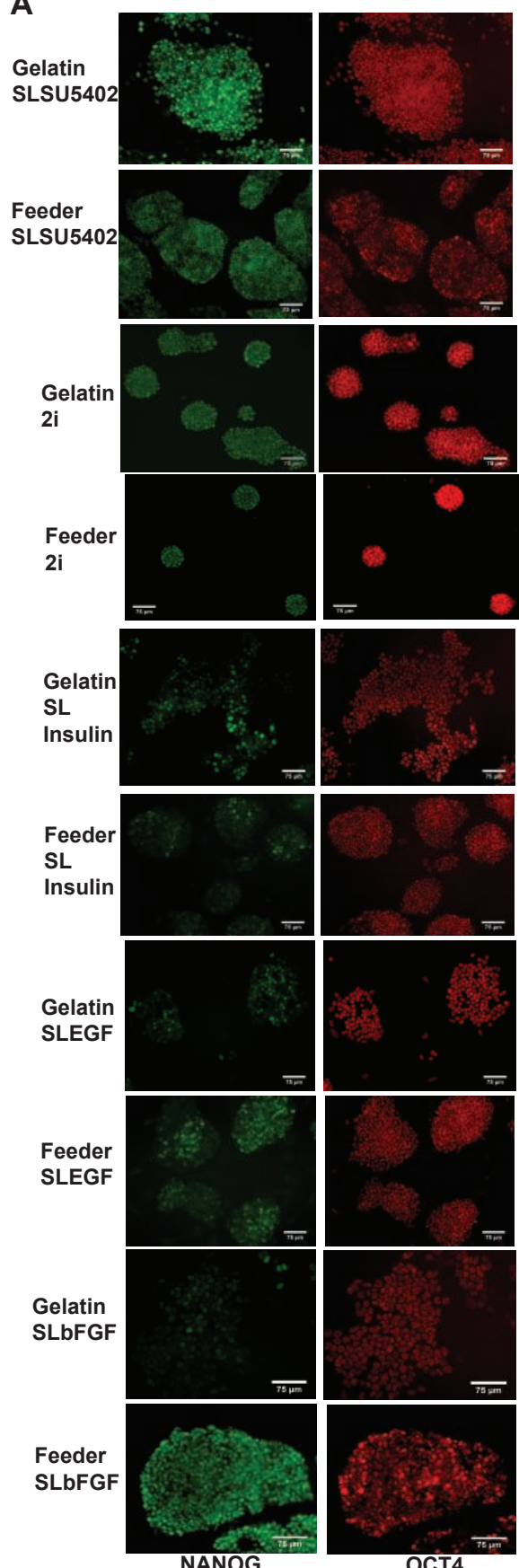

OCT4

B

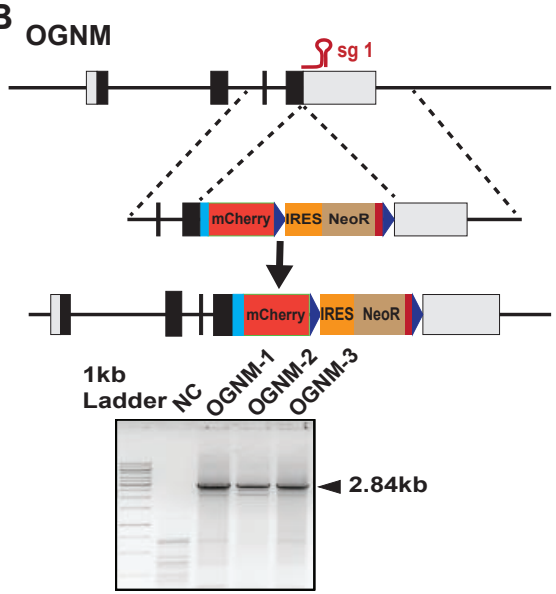

cccaacttggaacaaccagacetggaccaacceaacttggagca CCCAACTTOGAACAACCAGACCTOGACCAACCCAACTTOGAGCA

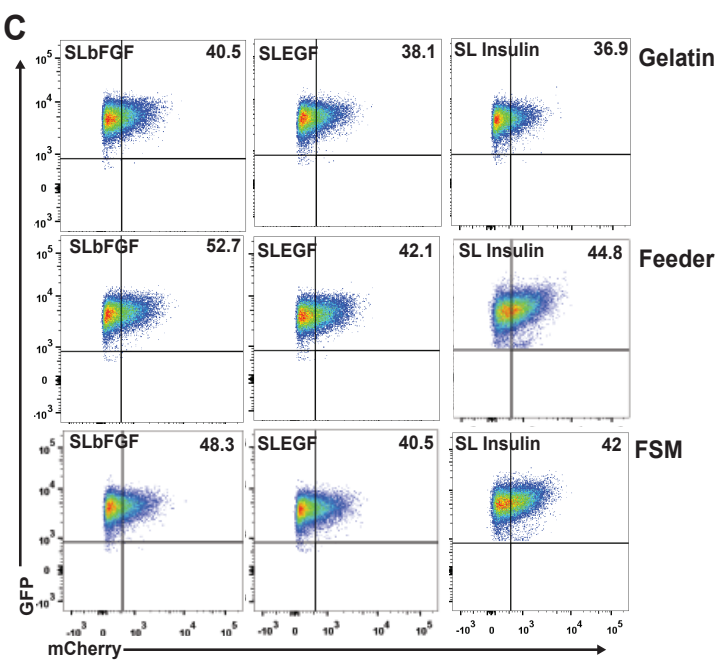

D

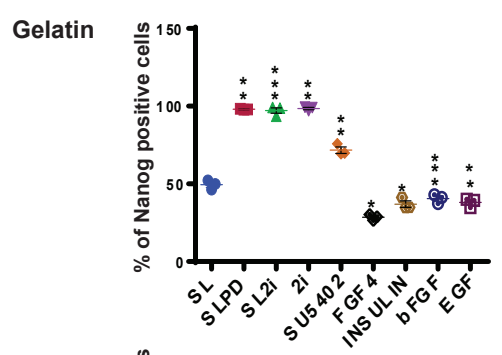

Feeder

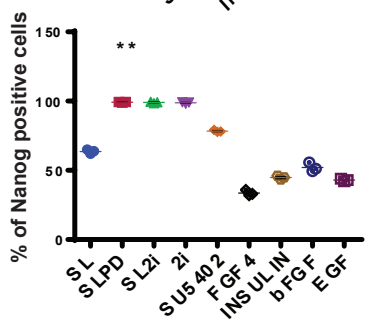

FSM

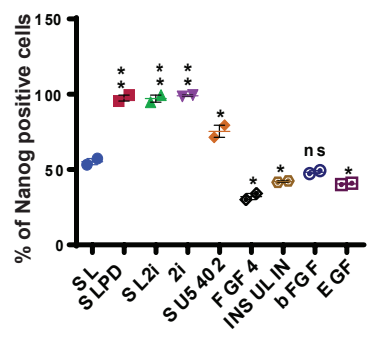

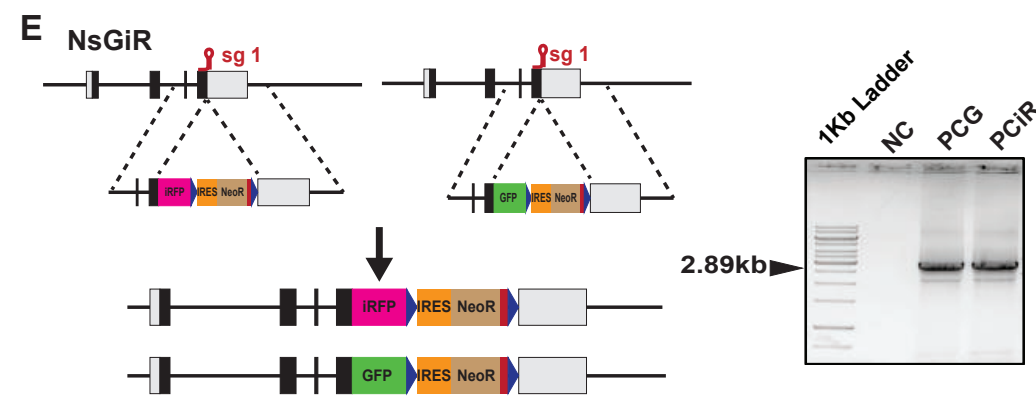

Nanog-iRFP

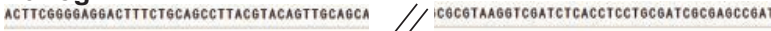

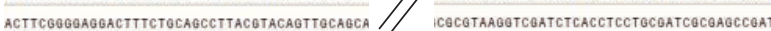

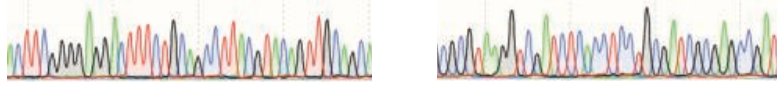
Nanog-GFP

ICCATTOCAGCTATCCECAGBGCTATCTGOTGAACBCATCTEG / OCACCCCACAAGCCTTGBAATTATTCCTOAACTACTCTGTO

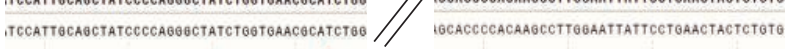




\section{Supplemental data Fig 6: FGF autocrine signaling regulates Nanog heterogeneity and monoallelic expression.}

Related to Figure 6.

(A) Immunofluorescence of NANOG and OCT4 in E14Tg2a cells cultured on gelatin or feeders in SLSU5402, 2i, SLInsulin, SLEGF, and SLbFGF. Scale bars represent $75 \mu \mathrm{M}$. (B) (top) Schematic of Knock-in of a T2AmCherry-loxP-IRESNeo-loxP cassette in frame with the last coding sequence of the last exon of Nanog in an Oct4-GFP cell line to generate OGNM cell line. The OGNM cell line will produce a T2A-mcherry protein from the knock-in allele and the Oct4 expression is reported by an Oct4-GFP transgenic reporter (addgene:60527) randomly integrated into the genome. (middle) Genotyping PCR using one primer from the mCherry cassette and the other from a sequence complementary to the sequence outside the homology arms. (bottom) Chromatogram of the Nanog-T2AmCherry junction in the knockin cells showing the Nanog coding sequences in frame with T2AmCherry sequence. (C) FACS profiles of OGNM cultured in SLbFGF, SLEGF, and SLInsulin on gelatin, feeders, and Feeder Secreted Matrix (FSM). (D) Percentage of Nanog-T2AmCherry expressing cells in indicated conditions cultured on gelatin ( $n=3$ ) (top), feeder $(n=3)$ (middle), and feeder secreted matrix $(n=2)$ (bottom) (E) (top) Schematic of the strategy of generating NsGiR cell line. iRFP-loxPIRESNeo-loxP is knocked-in in frame with the last coding sequence of Nanog in one allele and sfGFP-loxP-IRESNeo-loxP cassette into another allele. (middle) PCR genotyping of knock-in of iRFP-loxP-IRESNeo-loxP and sfGFP-loxP-IRESNeo-loxP into different alleles of Nanog. (bottom) Chromatogram of the PCR genotyping amplicons showing the junction of Nanog coding sequence with the iRFP670 or sfGFP sequences. 
A)

\section{E14Tg2a}

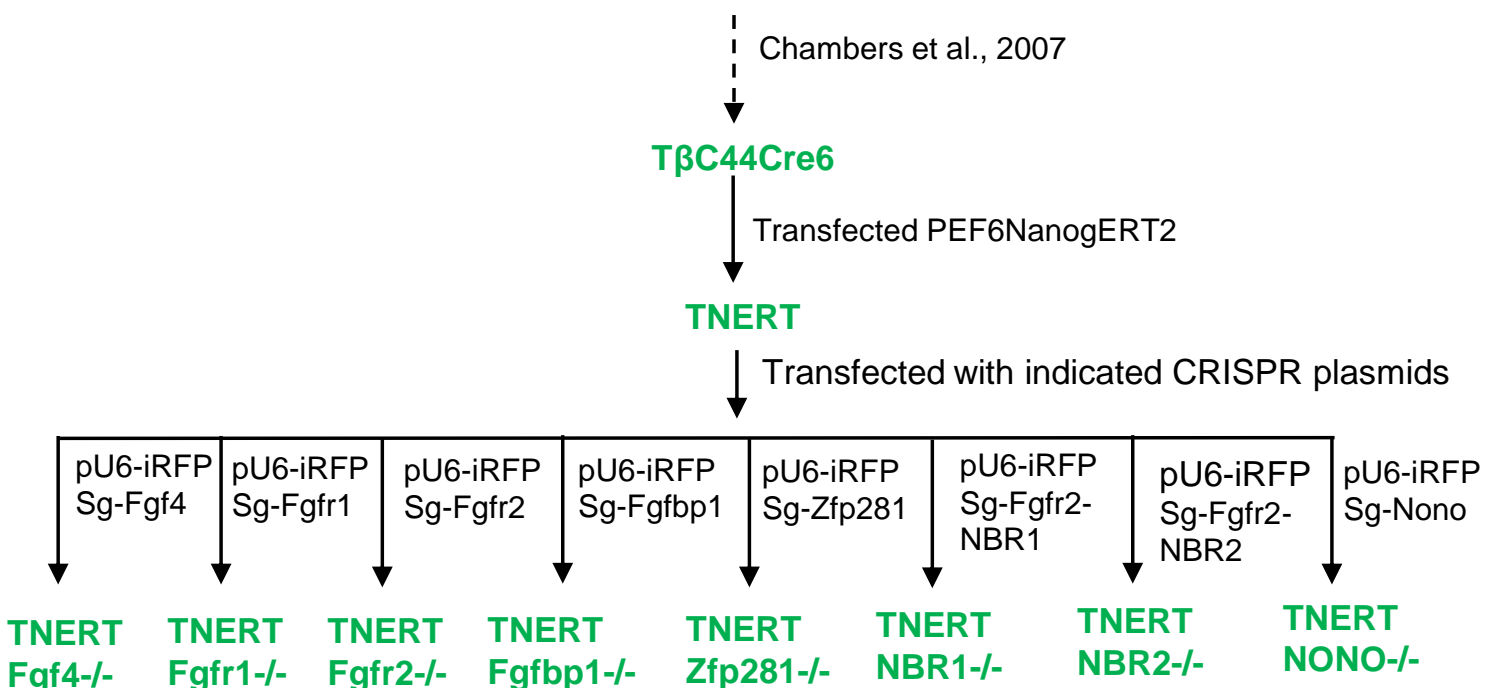

B) E14Tg2a

Chambers et al., 2007

TßC44Cre6

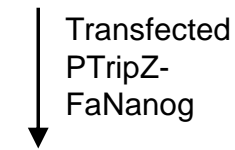

TDiN
C) E14Tg2a

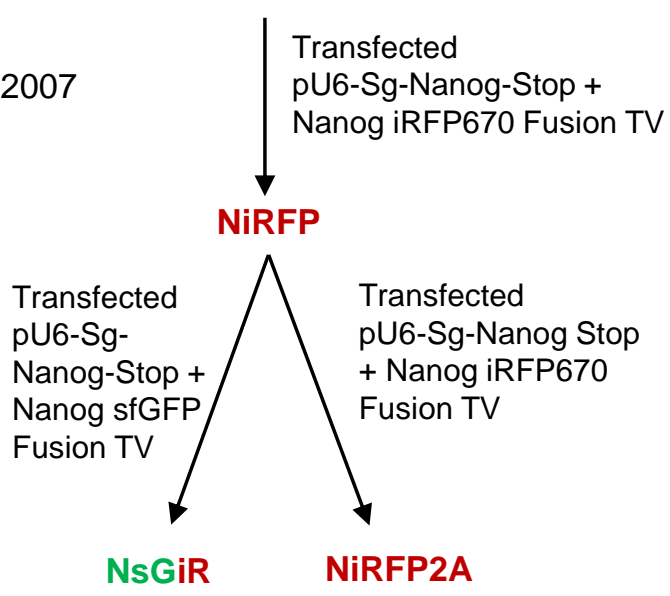

F) E14Tg2a

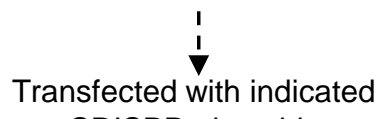
CRISPR plasmids

EOCT4-GFP

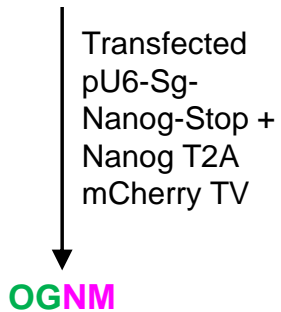

Transfected GOF18

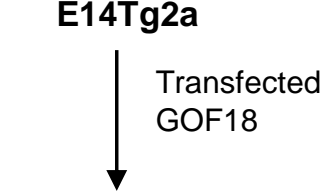

D) E14Tg2a

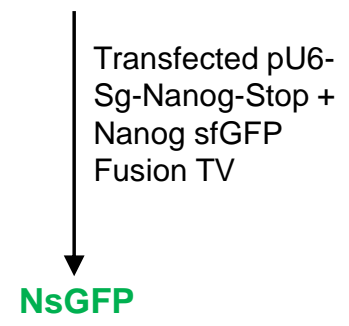

Transfected

PTripZ-

FaNanog

G) E14Tg2a

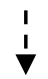

Transfected with indicated plasmids

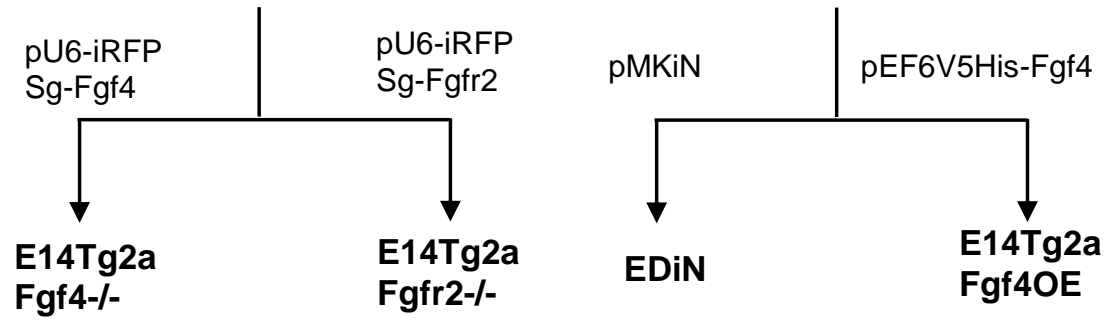


bioRxiv preprint doi: https://doi.org/10.1101/2021.06.28.450121: this version posted June 29, 2021. The copyright holder for this preprint (which was not certified by peer review) is the author/funder, who has granted bioRxiv a license to display the preprint in perpetuity. It is made available under aCC-BY-NC-ND 4.0 International license.

\section{Supplemental data Fig 7: A pedigree chart of cell lines used in this study.}

Related to STAR methods.

(A) A flow chart illustarting the lineage and process of generation of TNERT and generation of knock out cells lines in TNERT background. (B) A flow chart describing derivation of TDiN. (C) A flow chart depicting derivation of NsGiR and NiRFP2A from E14Tg2a. (D) A flow chart describing derivation of NsGFPDiN from E14Tg2a. (E) (D) A flow chart describing derivation of OGNM from E14Tg2a. (F) a flowchart depicting derivation of Fgf4/- and Fgfr2-/- ES cell lines from E14Tg2a. (G) a flowchart depicting derivation of EDiN and Fgf4OE (over expression) ES cell lines from E14Tg2a. 
bioRxiv preprint doi: https://doi org/101101/2021 $06.28,450121$ : this version posted June 29,2021 . The copyright holder for this preprint (which was not certified by peer review) is the author/funder, who has granted bioRxiv a license to display the preprint in perpetuity. It is made available under aCC-BY-NC-ND 4.0 International license.

\section{Supplemental Table 1. List of oligonucleotides used in the study}

\begin{tabular}{|c|c|}
\hline Name of the Oligo & Sequence \\
\hline \multicolumn{2}{|c|}{ Oligos for paired sgRNA Knock-out } \\
\hline \multirow[t]{2}{*}{ Fgf4 sgRNA1 } & CACCGCCGTGCGTGAGTTCGAGCTG \\
\hline & AAACCAGCTCGAACTCACGCACGGG \\
\hline \multirow{2}{*}{ Fgf4 sgRNA2 } & CACCGCGAAACGCGGGCCGACCAC \\
\hline & AAACGTGGTCGGCCCGCGTTTCGC \\
\hline \multirow[t]{2}{*}{ Fgfr1 sgRNA1 } & CACCGCGTCATCATCTTCCGAGGAT \\
\hline & AAACATCCTCGGAAGATGATGACGC \\
\hline \multirow[t]{2}{*}{ Fgfr1 sgRNA2 } & CACCGTTCTCTGGGGATGTCCAGTA \\
\hline & AAACTACTGGACATCCCCAGAGAAC \\
\hline \multirow{2}{*}{ Fgfr2 sgRNA1 } & CACCGCTGGGGGCGCTTCATCTGCC \\
\hline & AAACGGCAGATGAAGCGCCCCCAGG \\
\hline \multirow[t]{2}{*}{ Fgfr2 sgRNA2 } & CACCGCTCAGTGTAAGTAGGTTCC \\
\hline & AAACGGAACCTACTTACACTGAGC \\
\hline \multirow[t]{2}{*}{ Fgfbp1 sgRNA1 } & CACCGCACAGTCTTGGCCCACATTA \\
\hline & AAACTAATGTGGGCCAAGACTGTGC \\
\hline \multirow{2}{*}{ Fgfbp1 sgRNA2 } & CACCGATGTCGCCTGTAACATGTTG \\
\hline & AAACCAACATGTTACAGGCGACATC \\
\hline \multirow{2}{*}{$\begin{array}{l}\text { Fgfr2 NBR1 } \\
\text { sgRNA1 }\end{array}$} & CACCGTCGGAGCAGCTAGGCGAACT \\
\hline & AAACAGTTCGCCTAGCTGCTCCGAC \\
\hline \multirow{2}{*}{$\begin{array}{l}\text { Fgfr2 NBR1 } \\
\text { sgRNA2 }\end{array}$} & CACCGTTGTGTTTAGGGCCCCCCCT \\
\hline & AAACAGGGGGGGCCCTAAACACAAC \\
\hline \multirow{2}{*}{$\begin{array}{l}\text { Fgfr2 NBR2 } \\
\text { sgRNA1 }\end{array}$} & CACCGTGGAAGCAGCGGATGTTCGT \\
\hline & AAACACGAACATCCGCTGCTTCCAC \\
\hline \multirow{2}{*}{$\begin{array}{l}\text { Fgfr2 NBR2 } \\
\text { sgRNA2 }\end{array}$} & CACCGACCGGAGCTGCTCTCGGATC \\
\hline & AAACGATCCGAGAGCAGCTCCGGTC \\
\hline \multirow{2}{*}{$\begin{array}{l}\text { Nanog -stop codon } \\
\text { sgRNA }\end{array}$} & CACCGTATGAGACTTACGCAACATC \\
\hline & AAACGATGTTGCGTAAGTCTCATAG \\
\hline \multirow[t]{2}{*}{ Zfp281 sgRNA1 } & CACCGAGGCCTGGCTGCGGAGAGG \\
\hline & AAACCCTCTCCGCAGCCAGGCCTC \\
\hline \multirow[t]{2}{*}{ Zfp281 sgRNA1 } & CACCGCGGGGTATGAAAATCGGCAG \\
\hline & AAACCTGCCGATTTTCATACCCCGG \\
\hline \multirow[t]{2}{*}{ Nono sgRNA1 } & CACCGTTTTAATGATGGGTACCATC \\
\hline & AAACGATGGTACCCATCATTAAAAC \\
\hline \multirow[t]{2}{*}{ Nono sgRNA1 } & CACCGTTCCGAGAGAGCGTCAAGAC \\
\hline & AAACGTCTTGACGCTCTCTCGGAAC \\
\hline \multirow{3}{*}{ Fgf4 knock-out } & Genotyping primers \\
\hline & CGCAGCACTCACCGAACTCA \\
\hline & TGCCCACGTTGCAGTAGAGC \\
\hline \multirow[t]{2}{*}{ Fgfr1 knock-out } & GTCTAGACAGGGCGAATGCTGTTT \\
\hline & ACTTGAACTTCACCGTCTTGGCAG \\
\hline \multirow[t]{2}{*}{ Fgfr2 knock-out } & TCTGGGTTTAAGCAAGTTGGCACT \\
\hline & CAGCATACATGGTGGGTCAGAGAG \\
\hline \multirow[t]{2}{*}{ Fgfbp1 knock-out } & GAAAGTGAGAAGCTGAGTGAATGG \\
\hline & TATATGCACCTAGGTTTGTGGTCC \\
\hline Fgfr2 NBR1 & GAAGAAACTGCTGGAGTGTGGTCA \\
\hline & AGGGTAGTTCCAGGATACCTCAGC \\
\hline Fgfr2 NBR2 & AGAGGCTTTGGATGACTCTGCAAC \\
\hline knock-out & GCGATGATCTCGGAGGAAAACTCC \\
\hline Zfp281 knock-out & \begin{tabular}{|l|l} 
TGTGGAGAGGACGGCGTTATTTTT \\
\end{tabular} \\
\hline & TGAAACCCATACTACACTGGCTGC \\
\hline Nono Knock out & AGGTTTCCCTGCTTGTCTTTGTCT \\
\hline & GCAGCAACGCCCTTAATTTCAACA \\
\hline
\end{tabular}


bioRxiv preprint doi: $\mathrm{https}: / /$ doi.org/10 1101/2021.06 28.450121. this version posted June 292021 . The copyright holder for this preprint (which was not certified by peer review) is the author/funder, who has granted bioRxiv a license to display the preprint in perpetuity. It is made available under aCC-BY-NC-ND 4.0 International license.

\begin{tabular}{|c|c|}
\hline \multirow[t]{2}{*}{ Nanog-iRFP670 } & ACCCAGGGGTGACAAAGTATTCCAA \\
\hline & GCATTTTCCGTAATGCGCGTGATCC \\
\hline \multirow{2}{*}{ Nanog-sfGFP } & ACCCAGGGGTGACAAAGTATTCCAA \\
\hline & CGTTTGTAGCATCACCTTCACCCTC \\
\hline \multirow{2}{*}{$\begin{array}{l}\text { Nanog- } \\
\text { T2AmCherry }\end{array}$} & ACCCAGGGGTGACAAAGTATTCCAA \\
\hline & $\begin{array}{l}\text { TCGCCCTTGCTCACCATTGGCCCG } \\
\text { GGATTCTCTTC }\end{array}$ \\
\hline \multicolumn{2}{|r|}{ q-RT-PCR primers } \\
\hline \multirow[b]{2}{*}{ Dusp6 } & CTGCCATTAATGTGGCCATCCC \\
\hline & GTGTTCTCATTCCAGTCGCTGC \\
\hline \multirow[b]{2}{*}{ Nanog } & TGGTCCCCACAGTTTGCCTAGTTC \\
\hline & \begin{tabular}{|l|} 
CAGGTCTTCAGAGGAAGGGCGA \\
\end{tabular} \\
\hline \multirow[b]{2}{*}{ Oct4 } & GTGGAGGAAGCCGACAACAATGA \\
\hline & CAAGCTGATTGGCGATGTGAG \\
\hline \multirow[b]{2}{*}{ Sox2 } & TTTTCTAGTCGGCATCACCG \\
\hline & ACAAGAGAATTGGGAGGGGT \\
\hline \multirow[b]{2}{*}{ Klf4 } & GTGCAGCTTGCAGCAGTAAC \\
\hline & AGCGAGTTGGAAAGGATAAAGTC \\
\hline \multirow[b]{2}{*}{$\operatorname{Rexl}$} & CAGTCCAGAATACCAGAGTGGAA \\
\hline & ACTCTAGGTATCCGTCAGGGAAG \\
\hline \multirow[b]{2}{*}{$F g f r 2$} & CCCTGCGGAGACAGGTAACAG \\
\hline & AGCGTCAGCTTATCTCTGGGGA \\
\hline \multirow[b]{2}{*}{$F g f r l$} & ACCCTGTAGCTCCCTACTGGAC \\
\hline & TGGCATAGCGAACCTTGTAGCC \\
\hline \multirow[b]{2}{*}{$F g f 4$} & ACACGAGGGACAGTCTTCTGGA \\
\hline & TAGGCGTTGTAGTTGTTGGGCA \\
\hline \multirow[b]{2}{*}{$F g f b p 1$} & CTAACCTCAAGCTGGTGAACCCC \\
\hline & TCTCTAATGGCCATGGTCTGGGT \\
\hline \multirow[b]{2}{*}{ Gapdh } & CAACGGCACAGTCAAGGCCGA \\
\hline & CCCTTCAAGTGGGCCCCGG \\
\hline \multirow[b]{2}{*}{ Spry2 } & CCACCGATTGCTTGGAAGTTGG \\
\hline & AGGTCTTGGCAGTGTGTTCACC \\
\hline \multirow[b]{2}{*}{ Pre-Nanog-1 } & AGCCCAGTACTCAGGCTTGT \\
\hline & AGCATCACAACACGCACCT \\
\hline \multirow[b]{2}{*}{ Pre-Nanog-2 } & GCCAGCAGATGGCATAATTT \\
\hline & TGATGGCAATGCTGAGGTTA \\
\hline \multirow[b]{2}{*}{ Pre-Oct4 } & GTCCCAGCTGGTGTGACTCT \\
\hline & TCTTCTGCTTCAGCAGCTTG \\
\hline \multirow[b]{2}{*}{ Pre- $F g f 4$} & GACTACCTGCTGGGCCTCAAAA \\
\hline & TACTCAGCCCCCGAGACTACTAC \\
\hline \multirow[b]{2}{*}{ Pre-Fgfr 2} & CCCGTCCCTTCCCAAATCTGATA \\
\hline & TCACCTTGGGTCAGGATAACAAG \\
\hline \multirow[b]{2}{*}{ Pre-Fgfbpl } & GACTACCTGCTGGGCCTCAAAA \\
\hline & TACTCAGCCCCCGAGACTACTAC \\
\hline \multirow[b]{2}{*}{ Pre-Fgfrl } & CCCGTCCCTTCCCAAATCTGATA \\
\hline & TCACCTTGGGTCAGGATAACAAG \\
\hline & q-ChIP-PCR primers \\
\hline & GTGGGTGCACACAGAGAACAAC \\
\hline Nanog $5.5 \mathrm{~kb}$ & CTGAGAGCTCAGGCCCACAAAG \\
\hline & AACATTCCTTTCCCCACCCACA \\
\hline Nanog $-4.9 \mathrm{~kb}$ & AAGAGGTGGCTGGTAGCCAAAA \\
\hline
\end{tabular}


bioRxiv preprint doi: https:/doi.org/10.1101/2021.06 28.450121. this version posted June 292021 . The copyright holder for this preprint (which was not certified by peer review) is the author/funder, who has granted bioRxiv a license to display the preprint in perpetuity. It is made available under aCC-BY-NC-ND 4.0 International license.

\begin{tabular}{|c|c|}
\hline \multirow[b]{2}{*}{ Nanog $-4.7 \mathrm{~kb}$} & TGGGGTAAACTTAAGGCTATGG \\
\hline & AGCTCTAAGCCGGTTCTCATTT \\
\hline \multirow[b]{2}{*}{ Nanog $-3.9 \mathrm{~kb}$} & CCCTACCTCTCCTGAGGTGTGA \\
\hline & CATGCCTGAGGAAGTCAGAGGA \\
\hline \multirow[b]{2}{*}{ Nanog $-3.4 \mathrm{~kb}$} & TGTAGCCCTTGGTTAGTCCGAG \\
\hline & GGCAGGCATCACCAAAGTCATT \\
\hline \multirow[b]{2}{*}{ Nanog $-1.9 \mathrm{~kb}$} & GGTTCAGTCAGGCTGGGCAAT \\
\hline & CTGCTGCCACACTATCACTGTC \\
\hline \multirow[b]{2}{*}{ Nanog $-1.0 \mathrm{~kb}$} & AGCCGACTTAAGCTGGGTTAGA \\
\hline & TGCTCTAGCTGGTCCCAAACTC \\
\hline \multirow[b]{2}{*}{ Nanog $-0.05 \mathrm{~kb}$} & TAGGGTAGGAGGCTTGAGGGG \\
\hline & AAGTCAGAAGGAAGTGAGCCGC \\
\hline \multirow[b]{2}{*}{ Nanog $+.5 \mathrm{~kb}$} & CCGGTGATACGTTGGCCTTCTA \\
\hline & ACTGCCCCCGAACATATTCCAA \\
\hline \multirow[b]{2}{*}{ Nanog $+1.4 \mathrm{~kb}$} & GTTAGGAATGAACGGGTGGGGA \\
\hline & AGTAGACAGCCCTGAAAGCAGC \\
\hline \multirow[t]{2}{*}{ Fgf4 +3.5 kb } & GCCCAGAACCCAATTTTTATGCAC \\
\hline & CAAAGTCCCAGAGCCATTCCCTT \\
\hline \multirow[t]{2}{*}{ Fgf4 $-3.0 \mathrm{~kb}$} & TTAGCTCGCTTCAGGGAATGCTT \\
\hline & TTGCTGTCTGTAGCCTCCCATAA \\
\hline \multirow[t]{2}{*}{ Fgf4 $-6.5 \mathrm{~kb}$} & CACAAAGGTCGCTTAAGTGGTGG \\
\hline & ACACGATTTCCAGACTCCTCCAG \\
\hline \multirow[t]{2}{*}{ Fgf4 $-6.9 \mathrm{~kb}$} & TTAGGCACCCAAAGGCAGAATTG \\
\hline & GTCCTGTTATTCATGGCAGGGGA \\
\hline \multirow[t]{2}{*}{ Fgfr1-5kb } & TGGCCTTGGATGAATTGTTGGC \\
\hline & TTCCACCTCCCTTCAGGACACT \\
\hline \multirow[t]{2}{*}{ Fgfr1+2.5 kb } & TGGGGTGGTGTCTCTTCCTTTCAG \\
\hline & CAAGCCATTAGGGAGGGAGGCAA \\
\hline \multirow[t]{2}{*}{ Fgfbp1-1.4 kb } & TCCAGTGTGTGTGGTAAACAGGT \\
\hline & AACACTGCCTCTGGATGGTCTAC \\
\hline \multirow[t]{2}{*}{ Fgfr2 $-2.5 \mathrm{~kb}$} & TTTTGTCCCACTTCTTGGGGC \\
\hline & AATCTTCCACCAGCCTGGACTC \\
\hline \multirow[t]{2}{*}{ Fgfr2 -4.4 kb } & AAACAACGTAACGCATCCACTGT \\
\hline & TGCACAGATGACCTCTCGGAAC \\
\hline
\end{tabular}

